\title{
Critical Review of Natural Fiber Reinforced Hybrid Composites: Processing, Properties, Applications and Cost
}

\author{
M. J. Suriani ${ }^{1, *(\mathbb{D}, \text { R. A. Ilyas }}{ }^{2,3, *(\mathbb{D}, \text { M. Y. M. Zuhri }}{ }^{4,5, *(\mathbb{D}, \text { A. Khalina }}{ }^{5,6}$, M. T. H. Sultan ${ }^{5,7}$ (D) S. M. Sapuan ${ }^{4,5}$, \\ C. M. Ruzaidi ${ }^{1}$, F. Nik Wan ${ }^{1}$, F. Zulkifli ${ }^{1}$, M. M. Harussani ${ }^{4}$ (D) M. A. Azman ${ }^{1}$ (D) F. S. M. Radzi ${ }^{1}$ and
} Shubham Sharma ${ }^{8}$ iD

check for

updates

Citation: Suriani, M.J.; Ilyas, R.A.; Zuhri, M.Y.M.; Khalina, A.; Sultan, M.T.H.; Sapuan, S.M.; Ruzaidi, C.M.; Wan, F.N.; Zulkifli, F.; Harussani, M.M.; et al. Critical Review of Natural Fiber Reinforced Hybrid Composites: Processing, Properties, Applications and Cost. Polymers 2021, 13, 3514. https://doi.org/10.3390/ polym 13203514

Academic Editor: Emin Bayraktar

Received: 15 September 2021

Accepted: 7 October 2021

Published: 13 October 2021

Publisher's Note: MDPI stays neutral with regard to jurisdictional claims in published maps and institutional affiliations.

Copyright: (C) 2021 by the authors. Licensee MDPI, Basel, Switzerland This article is an open access article distributed under the terms and conditions of the Creative Commons Attribution (CC BY) license (https:/ / creativecommons.org/licenses/by/ $4.0 /)$
1 Faculty of Ocean Engineering Technology and Informatics, Universiti Malaysia Terengganu, Kuala Nerus 21030, Terengganu, Malaysia; ruzaidi@umt.edu.my (C.M.R.); wnfatihahnw@gmail.com (F.N.W.); fakhratulz@umt.edu.my (F.Z.); asyrafazman23@yahoo.com (M.A.A.); fathinsakinah96@gmail.com (F.S.M.R.)

2 School of Chemical and Energy Engineering, Faculty of Engineering, Universiti Teknologi Malaysia (UTM), Johor Bahru 81310, Johor, Malaysia

3 Centre for Advanced Composite Materials (CACM), Universiti Teknologi Malaysia (UTM), Johor Bahru 81310, Johor, Malaysia

4 Advanced Engineering Materials and Composites Research Centre (AEMC), Department of Mechanical and Manufacturing Engineering, Faculty of Engineering, Universiti Putra Malaysia, Serdang 43400, Selangor, Malaysia; sapuan@upm.edu.my (S.M.S.); mmharussani17@gmail.com (M.M.H.)

5 Laboratory of Biocomposite Technology, Institute of Tropical Forestry and Forest Products (INTROP), Universiti Putra Malaysia, Serdang 43400, Selangor, Malaysia; khalina@upm.edu.my (A.K.); thariq@upm.edu.my (M.T.H.S.)

6 Department of Biological and Agricultural Engineering, Faculty of Engineering, Universiti Putra Malaysia, Serdang 43400, Selangor, Malaysia

7 Department of Aerospace Engineering, Faculty of Engineering, Universiti Putra Malaysia, Serdang 43400, Selangor, Malaysia

8 Department of Mechanical Engineering, IK Gujral Punjab Technical University, Main Campus-Kapurthala, Punjab 144603, India; shubham543sharma@gmail.com

* Correspondence: surianimatjusoh@umt.edu.my (M.J.S.); ahmadilyas@utm.my (R.A.I.); zuhri@upm.edu.my (M.Y.M.Z.)

Abstract: Increasing scientific interest has occurred concerning the utilization of natural fiberenhanced hybrid composites that incorporate one or more types of natural enhancement. Annual natural fiber production is estimated to be 1,783,965 $\times 10^{3}$ tons/year. Extensive studies have been conducted in the domains of natural/synthetic as well as natural/natural hybrid composites. As synthetic fibers have better rigidity and strength than natural fibers, natural/synthetic hybrid composites have superior qualities via hybridization compared to natural composites in fibers. In general, natural fiber compounds have lower characteristics, limiting the use of natural composites reinforced by fiber. Significant effort was spent in enhancing the mechanical characteristics of this group of materials to increase their strengths and applications, especially via the hybridization process, by manipulating the characteristics of fiber-reinforced composite materials. Current studies concentrate on enhancing the understanding of natural fiber-matrix adhesion, enhancing processing methods, and natural fiber compatibility. The optimal and resilient conceptions have also been addressed due to the inherently more significant variabilities. Moreover, much research has tackled natural fiber reinforced hybrid composite costs. In addition, this review article aims to offer a review of the variables that lead to the mechanical and structural failure of natural fiber reinforced polymer composites, as well as an overview of the details and costings of the composites.

Keywords: natural fiber; hybrid composite; cellulose; costing; processing; fiber-matrix adhesion

\section{Introduction}

Composite materials are produced from a combination of two or more elements that are easily distinguishable to enhance the characteristics of the individual element $[1,2]$. 
Newly invented materials may be favored for various reasons, e.g., they are stronger, more lightweight, and less costly than existing materials [3-5]. In general, the individual materials making up composites are known as constituents. Principally, most composites comprise two constituent materials-reinforcement and matrix - however, in general, the composites may contain not only two components, matrix and reinforcement, but also other types of components: fillers, compatibilizers, coupling agents, pigments, lubricants, surfactants, solvents, etc. Only the simplest textile-based composites, also called textolites, contain two constituents, polymer matrix and reinforcement such as natural, synthetic or hybrid fibers, or fabrics. The reinforcement is significantly stiffer and stronger than the matrix, contributing to the composites' superior characteristics [6,7]. The main functions of the polymer matrix in textile-based composites are to bind reinforcements (fabric, fibers, or nanofibers) and maintain the integrity of the composite.

Composites' reinforcements can be fabrics elements, fibers, or nanofibers [8-10]. Fiber is defined as one very long axis with two other axes that frequently are either circular or near-circular. The fibers have a pronounced axial orientation. As is known, Young's modulus and tensile strength of fiber in the longitudinal direction (along the fiber axis) is usually an order of magnitude higher than in the lateral direction of the fiber. Nanofibers have an ideal form; however, they are smaller in diameter and length compared to fibers [11]. Figure 1 shows the type of reinforcements in composites.

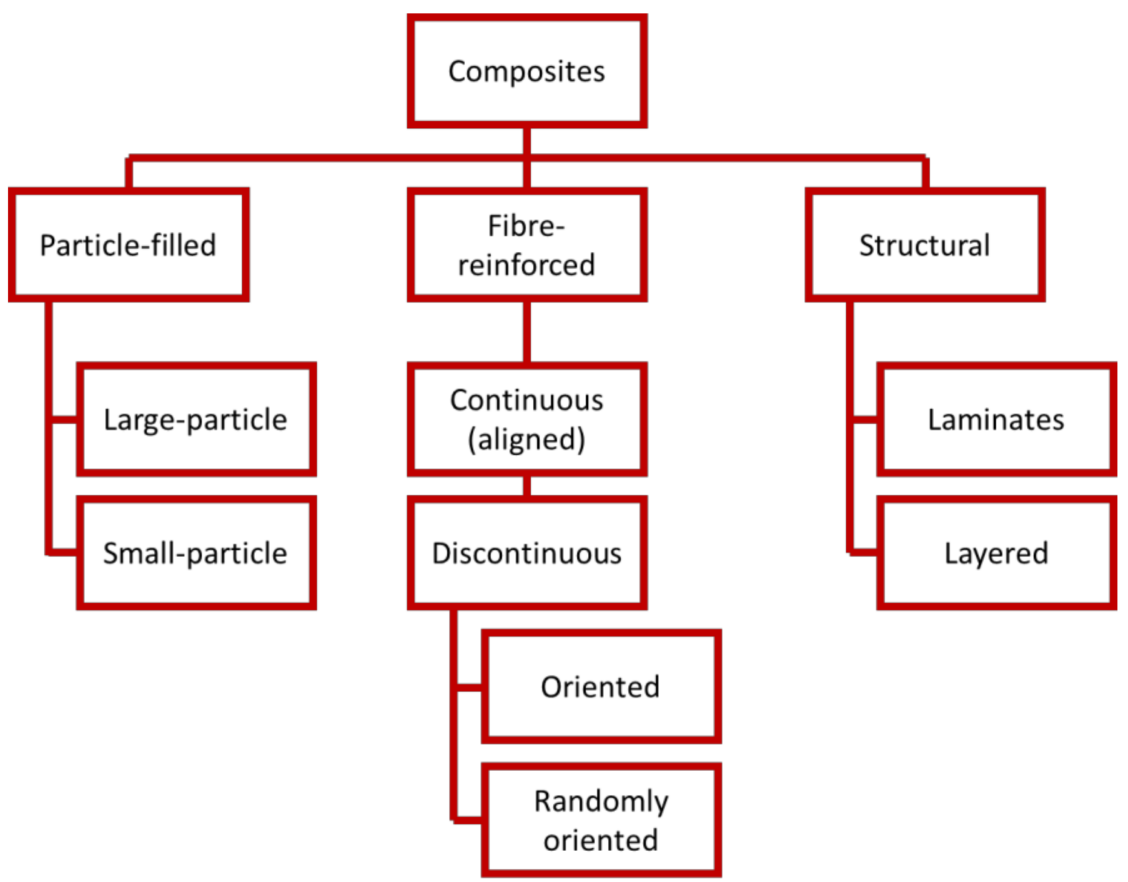

Figure 1. Types of reinforcements in composites. Redrawn with permission from Saba and Jawaid [12].

The matrix might be thermoset, thermoplastic, or biopolymer. Polyvinyl chloride (PVC) is the most common thermoplastic matrix used in natural fiber composites. Besides this, due to the limited compatibility of nonpolar hydrophobic polyethylene and polypropylene with polar and hydrophilic natural cellulose fibers, these thermoplastics typically are not employed as a matrix for natural cellulose fibers. Meanwhile, polyester, epoxy, and phenolics are the most often used thermoset polymers [13,14].

Nowadays, the availability of bio-based polymer matrices on the market is comparatively meager; however, it has been speedily expanding, thanks to a huge number of industrial investigations and continuous research into the advantages of these materials, as well as their practicability in actual applications. The preliminary data on the essential characteristics of composites attained from eco-based matrices were reported in $[15,16]$. 


\section{Natural Fiber (NF)}

Fiber is the continuous filaments hair-like material of elongated piece that is similar to a thread, while fibers is a group of fiber that can be coiled into rope, filaments, or thread [17-19]. They are useful as of the composite materials' element and were also formed into sheets to produce felt or paper. Fibers are categorized into three groups: (1) natural fiber and (2) man-made, and (3) synthetic fiber. Natural fibers are either animal, plant or mineral-based that are extracted from nature without compromising the environment. Commonly used animal-based natural fibers including feather, wool, silk, hair, etc. Examples of plant-based natural fibers are banana, jute, hemp, bamboo, flax, sisal, etc., which are broadly applied to manufacture natural fiber reinforced polymer (NFRP) composites [20]. The classifications of natural fibers are shown in Figure 2, and the annual natural fiber production is presented in Table 1.

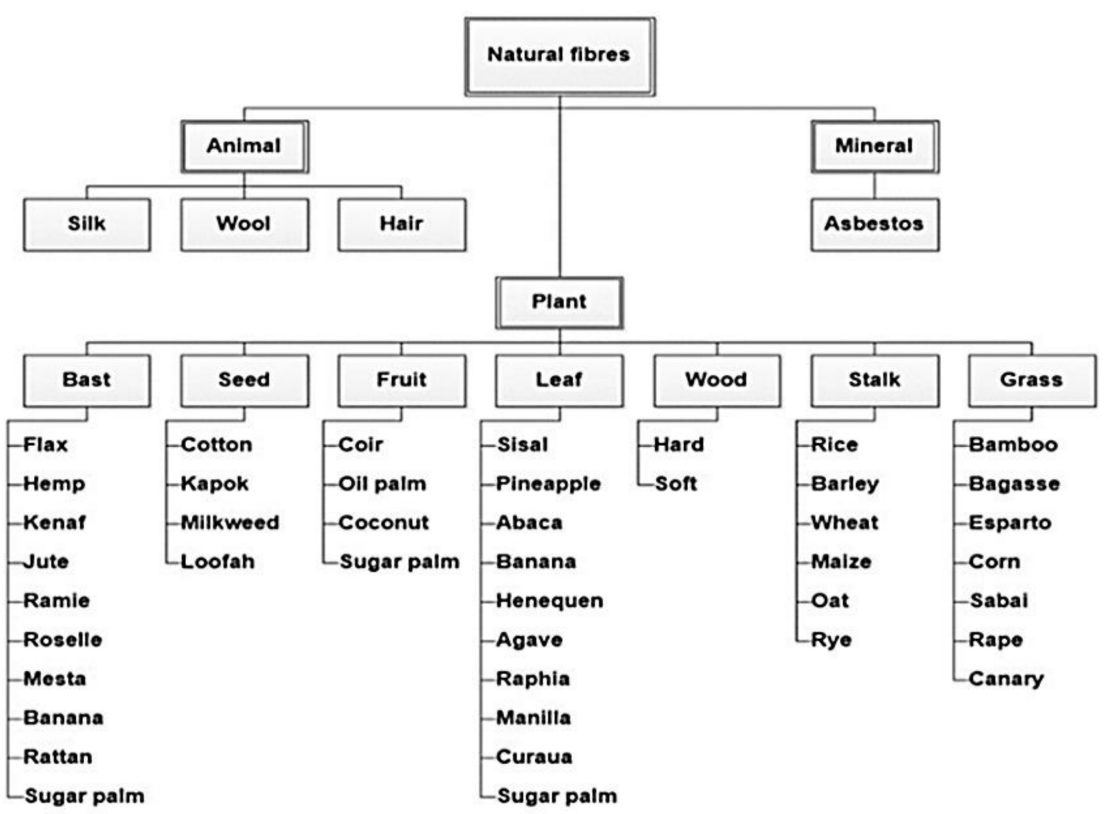

Figure 2. Classifications of natural fibers. Redrawn with permission from Jawaid and Khalil [12].

Over the past few years, natural fibers have become eminent reinforcing fibers in polymer-matrix composites (PMC). They offer rapidly increasing and abundant characteristics, allowing them to be obtained at a small cost. Numerous attempts in terms of studies have been performed worldwide to prove the eligibility of natural fiber-based composites to substitute the synthetic as newly engineered fibers. Due to the growing need for renewable, cost-effective, and environmentally friendly materials, the use of natural fibers as composite materials' reinforcement has proliferated over the years.

When compared to glass fiber composites, natural fiber composites are more advantageous for being more lightweight, biodegradable in nature, ease of machinability, zero toxicity, cheap cost, convenience, and non-abrasive nature $[13,21,22]$. Many natural fiber composites are reputable and have been satisfactorily proven in research. The number of natural fiber composites has been investigated previously in terms of their physical and mechanical properties, such as arrowroot, hemp, sisal, coir, jute, kenaf, date, pine cone, vakka and bamboo [23-27]. 
Table 1. Annual natural fibers production. Extracted with permission from [28].

\begin{tabular}{ccc}
\hline Natural Fiber & Source & $\begin{array}{c}\text { World Production } \\
\left(\times \mathbf{1 0}^{\mathbf{3}} \text { Tons }\right)\end{array}$ \\
\hline Abaca & Leaf & 70 \\
Banana & Stem & 200 \\
Bamboo & Stem & 10,000 \\
Broom & Stem & Abundant \\
Coir & Fruit & 100 \\
Cotton lint & Seed & 18,500 \\
Elephant & Stem & Abundant \\
Flax & Stem & 810 \\
Hemp & Stem & 215 \\
Jute & Stem & 2500 \\
Kenaf & Stem & 770 \\
Linseed & Fruit & Abundant \\
Oil Palm Fruit & Fruit & Abundant \\
Ramie & Stem & 100 \\
Rice Husk & Grain & Abundant \\
Roselle & Stem & 250 \\
Sisal & Leaf & 380 \\
Sun hemp & Stem & 70 \\
Wood & Stem & $1,750,000$ \\
\hline
\end{tabular}

\section{Recent Development of Natural Fiber Reinforced Hybrid Composites}

It is known that natural fibers possess some limitations compared with those common fibers such as glass and carbon, where it is having more inferior mechanical properties and a higher water absorption [29]. Therefore, an introduction of hybrid biocomposites consists of two or more fibers in one matrix is seen as a solution to enhance the natural fiber-reinforced polymer composites' properties. Zahra et al. [30] stated that hybridizing one natural fiber with another natural fiber/synthetic fiber in one matrix will improve it's thermal and mechanical than the individual fiber composites [31]. This has shown that hybrid composites are more reliable for various applications, besides being more environmentally friendly.

The hybridization of natural fiber-based reinforced polymer composites can be done through a combination of natural-natural fibers, natural-synthetic fibers, natural fiber with carbonaceous materials, and natural fiber with metal [32]. Due to their varied properties and considerations of interfacial adhesion, hybrid natural fiber composite materials are facing difficulties in fabrication. Composites are manufactured in a variety of ways, such as through basic mixing and open or closed molding. Many factors can affect the interactions between the fiber and matrix, for example, and could be mild owing to the existing van der Waals forces, hydrogen bonding, and weak electrostatic interactions. In addition, a good interaction could also exist due to the chemical interactions between those materials. Therefore, studies on hybrid natural fiber composites keep increasing in order to discover the ability of hybrids to be a possible alternative, replacing various petroleum-based products. Some examples of the studies of hybrid natural fiber composites are presented in Table 2. 
Table 2. Natural fiber reinforced hybrid composites.

\begin{tabular}{|c|c|c|c|c|}
\hline Natural Fiber & Matrix & Hybrids & Process & Ref. \\
\hline \multicolumn{5}{|c|}{ Sugar palm fiber (SPF) } \\
\hline Sugar palm fiber & Unsaturated polyester & Woven glass & Compression molding & [28] \\
\hline Sugar palm fiber & Unsaturated polyester & Glass fiber & Hand lay-up & [33] \\
\hline Sugar palm fiber & Thermoplastic polyurethane & Glass fiber & Melt compounding & [34] \\
\hline Sugar palm yarn fiber & Epoxy & Carbon fiber & Hand lay-up & {$[35]$} \\
\hline $\begin{array}{l}\text { Benzoyl treated sugar } \\
\text { palm fiber }\end{array}$ & Epoxy & Glass fiber & Hand lay-up & {$[36,37]$} \\
\hline Sugar palm fiber & $\begin{array}{c}\text { Thermoplastic sugar palm } \\
\text { starch/agar }\end{array}$ & Seaweed fiber & Hydraulic thermo-press & {$[38]$} \\
\hline Sugar palm fiber & Thermoplastic polyurethane & Roselle fiber & Hot press & [39] \\
\hline Sugar palm fiber & Cornstarch & Cornhusk & Solution casting & [40] \\
\hline Sugar palm yarn fiber & Unsaturated polyester & Glass fiber & Sheet molding & [41] \\
\hline Sugar palm fiber & Cassava starch & Cassava fiber & Casting & [42] \\
\hline Sugar palm fiber & Polypropylene & Kenaf fiber & Compression molding & [43] \\
\hline Sugar palm fiber & Cornstarch & Cornstalk fiber & Solution casting & [44] \\
\hline Sugar palm fiber & Epoxy & Ramie fiber & Compression molding & [45] \\
\hline Sugar palm fiber & Vinyl ester & Roselle fiber & Hand lay-up & {$[46]$} \\
\hline Sugar palm fiber & Polypropylene & Glass fiber & $\begin{array}{l}\text { Film stacking and hot } \\
\text { compression }\end{array}$ & {$[47]$} \\
\hline \multicolumn{5}{|c|}{ Kenaf fiber (KF) } \\
\hline Kenaf fiber & Epoxy & Glass fiber & Sheet molding & [48] \\
\hline Kenaf fiber & unsaturated polyester (UPE) & Glass fiber & Sheet molding & [49] \\
\hline Kenaf fiber & Epoxy & Silica & Hand lay-up & {$[50,51]$} \\
\hline Kenaf fiber & Epoxy & Bamboo fiber/nanoclay & Hand lay-up & [52] \\
\hline Kenaf fiber & Epoxy & Oil palm/montmorillonite & Hand lay-up & [53] \\
\hline Kenaf fiber & $\begin{array}{c}\text { Polypropylene-grafted maleic } \\
\text { anhydride (PP-g-MA) }\end{array}$ & Graphene nanosheets & Hot press & {$[54]$} \\
\hline Kenaf core & Polypropylene & Bleached nanocellulose & Melt mixing compounding & [55] \\
\hline Kenaf fiber & Epoxy & Glass fiber & Filament winding & [56] \\
\hline Kenaf fiber & Epoxy & Pet yarn & Cold press & [57] \\
\hline Kenaf fiber & Polyethylene terephthalate & Glass fiber & Compression molding & [58] \\
\hline Kenaf fiber & Epoxy & Kevlar & Hand lay-up & [59] \\
\hline Kenaf fiber & Polyester & Banana fiber & Hand lay-up & [60] \\
\hline Kenaf fiber & Indian almond fiber & Kenaf fiber & Hand lay-up & [61] \\
\hline Kenaf fiber & Epoxy & Glass/waste tea leaf fiber & Compression molding & [62] \\
\hline Kenaf fiber & Epoxy & Oil palm fiber & Hand lay-up & [63] \\
\hline Woven kenaf fiber & Polypropylene & Glass fiber & Hot press molding & [64] \\
\hline Kenaf fiber & Polypropylene & E-glass & Hot compression molding & [65] \\
\hline Kenaf fiber & Epoxy & Bamboo fiber & Hand lay-up & [66] \\
\hline \multirow[t]{2}{*}{ Kenaf fiber } & Polypropylene & Wood flour & Injection molding & [67] \\
\hline & Polylactic acid (PLA) & Kenaf & $\begin{array}{l}\text { Fused Deposition Modeling } \\
\text { (FDM) }\end{array}$ & [68] \\
\hline \multicolumn{5}{|c|}{ Oil palm empty fruit bunches fiber (OPEFB) } \\
\hline $\begin{array}{l}\text { Oil palm empty fruit } \\
\text { bunches fiber }\end{array}$ & Epoxy & $\mathrm{MgO}_{2}$ pet yarn & Compression molding & [69] \\
\hline $\begin{array}{l}\text { Oil palm empty fruit } \\
\text { bunches fiber }\end{array}$ & Polyester resin & $\mathrm{MgO}_{2}$ pet yarn & Compression molding & [69] \\
\hline $\begin{array}{l}\text { Oil palm empty fruit } \\
\text { bunches fiber }\end{array}$ & Epoxy & Woven kenaf fabric & Hand lay-up & [70] \\
\hline $\begin{array}{l}\text { Oil palm empty fruit } \\
\text { bunches fiber }\end{array}$ & Polypropylene (PP) matrix & & Injection molding & [71] \\
\hline $\begin{array}{l}\text { Oil palm empty fruit } \\
\text { bunches fiber }\end{array}$ & Phenolic formaldehyde (PF) resin & Sugarcane bagasse (SCB) fiber & Hand lay-up & [72] \\
\hline $\begin{array}{l}\text { Oil palm empty fruit } \\
\text { bunches fiber }\end{array}$ & Resin & Gamma-irradiated kevlar & Hand lay-up & [73] \\
\hline $\begin{array}{l}\text { Oil palm empty fruit } \\
\text { bunches fiber }\end{array}$ & Recycled polypropylene (RPP) & Glass fiber & Extrusion and injection molding & [74] \\
\hline Oil palm fibers & Polyester resin & $\begin{array}{l}\text { Chopped strand mat (CSM) } \\
\text { glass fibers }\end{array}$ & Hybrid laminates & [75] \\
\hline $\begin{array}{l}\text { Oil palm empty fruit } \\
\text { bunches fiber }\end{array}$ & Polypropylene & Glass fiber & Hot pressing & [76] \\
\hline
\end{tabular}


Table 2. Cont.

\begin{tabular}{|c|c|c|c|c|}
\hline Natural Fiber & Matrix & Hybrids & Process & Ref. \\
\hline \multicolumn{5}{|c|}{ Pineapple leaf fibers (PALF) } \\
\hline Pineapple leaf fibers & Carbon hybrid laminate & & Vacuum infusion & [77] \\
\hline Pineapple leaf fibers & Polylactic acid (PLA) & Alkali treated coir & Compression molding & [78] \\
\hline Pineapple leaf fibers & Vinyl ester & Glass fiber & Automated spray-up & [79] \\
\hline Pineapple leaf fibers & Polyester & Banana/glass fiber & Hand lay-up & [80] \\
\hline $\begin{array}{c}\text { Silane treated pineapple } \\
\text { leaf fiber }\end{array}$ & Phenolic hybrid & Kenaf fiber & Hydraulic pressure hot press & [81] \\
\hline Pineapple leaf fibers & Polyester & Sisal fiber & Injection molding & [82] \\
\hline \multicolumn{5}{|c|}{ Bamboo fiber (BF) } \\
\hline Long bamboo fiber & Epoxy & & Compression molding & [83] \\
\hline Short bamboo fiber & POlypropylene & Glass fiber & Injection molding & [84] \\
\hline Bamboo fiber & $\begin{array}{l}\text { Maleic anhydride grafted } \\
\text { polypropylene (MAPP) }\end{array}$ & Glass fiber & Injection molding & [85] \\
\hline Bamboo fiber & Polypropylene & Glass fiber & Compression molding & {$[86,87]$} \\
\hline Bamboo fiber & Epoxy & Ceramic fillers & Compression molding & [88] \\
\hline Bamboo fiber & Epoxy polymer & Jute fiber & Hand lay-up & [89] \\
\hline Bamboo fiber & Epoxy & Flax fiber mat & Hand lay-up & [90] \\
\hline Bamboo fiber & Epoxy & Sisal fiber & Hand lay-up & [91] \\
\hline Bamboo fiber & Epoxy & Cotton yarn & Compression molding & [92] \\
\hline Bamboo leaf fiber ash & Aluminium metal matrix & Rice husk ash & Hand lay-up & [93] \\
\hline Bamboo fiber & Epoxy & Kenaf fiber & Hand lay-up & [66] \\
\hline \multicolumn{5}{|c|}{ Jute fiber (JF) } \\
\hline Alkali treated jute fiber & Vinyl ester resin & & Compression molding & [94] \\
\hline Jute fiber & Epoxy & Carbon fiber & Hand lay-up & [95] \\
\hline Jute fiber & Epoxy polymer & Bamboo fiber & Hand lay-up & [89] \\
\hline Woven jute & Polyester & Glass fabric & Hand lay-up & [96] \\
\hline Woven jute & Vinyl ester & Ramie fiber & Hand lay-up & [97] \\
\hline Jute fiber & Epoxy resin & Glass fiber & Resin infusion & [98] \\
\hline Jute fiber & Polyester & Glass fiber & Injection molding & [99] \\
\hline Jute fiber & & Hemp/Flax fiber & Hand lay-up & [100] \\
\hline Jute fiber & Polyester & Cotton woven fabric & Hand lay-up & [101] \\
\hline Jute fiber & Polyester & Woven fabric basalt fiber & Compression molding & [102] \\
\hline \multicolumn{5}{|c|}{ Hemp fiber (HF) } \\
\hline $\begin{array}{l}\text { Alkaline-treated hemp } \\
\text { fiber }\end{array}$ & Polyester resin & Carbon fiber & Hand lay-up & [103] \\
\hline Hemp fiber mat & Green epoxy & Sisal fiber & $\begin{array}{l}\text { Hand lay-up method and hot } \\
\text { press }\end{array}$ & [104] \\
\hline Hemp fiber & Unsaturated polyester & Soybean oil/nanoclay & Compression molding & [105] \\
\hline Hemp fiber & Polylactic acid & Sisal fiber & Injection molding & [106] \\
\hline Hemp fiber & HDPE & Basalt fiber & Injection molding & [107] \\
\hline Interwoven hemp fiber & PET & & Vacuum infusion & [108] \\
\hline \multicolumn{5}{|c|}{ Flax fiber (FF) } \\
\hline Flax fiber & Epoxy & Hemp fiber & Hand lay-up & [100] \\
\hline Flax fiber & Epoxy & Jute/hemp fiber & Hand lay-up & [100] \\
\hline Flax fiber & Vinyl ester & Glass fiber & Resin infusion & [109] \\
\hline Short flax fiber & Polypropylene & & Injection molding & [110] \\
\hline Flax fiber & Polypropylene & Kenaf/hemp fiber & Compression molding & [111] \\
\hline Flax fiber & Polylactic acid & Kenaf/hemp fiber & Compression molding & [111] \\
\hline Flax fiber & Epoxy & & Vacuum infusion & [112] \\
\hline Flax fiber & Vinyl ester & Basalt fiber & Vacuum assisted resin infusion & [113] \\
\hline Flax fiber & Epoxy resin & Glass fiber & Compression molding & [114] \\
\hline Flax fiber & Vinyl ester & Glass fiber & Resin infusion & [109] \\
\hline Flax fiber & Barium sulphate & Woven aloevera & Compression molding & [115] \\
\hline \multicolumn{5}{|c|}{ Ramie fiber (RF) } \\
\hline Ramie fiber & Polylactic acid & Poly(E-caprolactone) & Compression molding & [116] \\
\hline Ramie fiber & PVA & Glass fiber & Compression molding & [117] \\
\hline Ramie fiber & Vinyl ester & Jute fiber & Hand lay-up & {$[97]$} \\
\hline Ramie woven & Epoxy & & Hand lay-up & [118] \\
\hline Ramie cloth & Unsaturated polyester resin & & Resin casting & [119] \\
\hline
\end{tabular}


Table 2. Cont.

\begin{tabular}{|c|c|c|c|c|}
\hline Natural Fiber & Matrix & Hybrids & Process & Ref. \\
\hline \multicolumn{5}{|c|}{ Abaca/banana fiber (ABF) } \\
\hline Abaca/banana fiber & Polypropylene & & $\begin{array}{l}\text { Mixer-injection, mixer } \\
\text { compression, and direct } \\
\text { compression moldings }\end{array}$ & [120] \\
\hline Abaca fiber & Cement & Silica & & [121] \\
\hline $\begin{array}{c}\text { Enzyme modified abaca } \\
\text { fiber }\end{array}$ & Polypropylene & & Injection molding & [122] \\
\hline Abaca fiber & Polyethylene & Banana fiber & Rotational molding & [123] \\
\hline Banana fiber & Low density polyethylene & & Compression molding & [124] \\
\hline Abaca fiber & Polystyrene & & Compression molding & [125] \\
\hline Plain weave abaca fiber & Polyester resin & & Hand lay-up & [126] \\
\hline Banana fiber & Polyvinyl alcohol resin & & Hand lay-up & [127] \\
\hline \multicolumn{5}{|c|}{ Sisal fiber (SF) } \\
\hline Sisal fiber & Phenolic resin & Aramid fiber & Compression molding & [128] \\
\hline Sisal fiber & Bioepoxy & Hemp fiber & Hand lay-up & [104] \\
\hline Sisal fiber & Polyester & Bamboo fiber & Hand lay-up & [91] \\
\hline Sisal fiber & PLA & Banana fiber & Injection molding & [129] \\
\hline Sisal fiber & Unsaturated polyester & Carbon fibers & Hand lay-up & [130] \\
\hline Sisal fiber & Waste carbon & Glass fiber & $\begin{array}{l}\text { Single extrusion and press } \\
\text { consolidation }\end{array}$ & [131] \\
\hline Sisal fiber & Epoxy & Jute fiber & Hand lay-up & [132] \\
\hline
\end{tabular}

\subsection{Sugar Palm Fiber Reinforced Hybrid Composites}

Arenga Pinnata (also known as sugar palm) is a versatile palm species with wide applications in foods and beverages [133], timber commodities [134], biofibers [135-141], biopolymers [142,143] and biocomposites [144-153]. Sugar palm fibers are recognized for their great durability, as well as their resistance to seawater. Sugar palm fibers have been used to produce ropes for ship cordages that have confirmed the good performance in saltwater [154]. Via the hand-lay-up technique, Misri et al. [28] manufactured a small boat using innovative material, a hybrid of sugar palm fiber and fiberglass-reinforced unsaturated polyester. The mechanical properties of the hybrid boat were investigated via the tensile and impact tests and were found the increased impact strength of $2.471 \mathrm{~kJ} / \mathrm{m}^{2}$ and tensile modulus of $1840.6 \mathrm{MPa}$. Sanyang et al. [155] reported that the sugar palm fiber demonstrated a lower density than the commercial E-glass fiber of $1.22-1.26 \mathrm{~kg} / \mathrm{m}^{3}$ and $2.55 \mathrm{~kg} / \mathrm{m}^{3}$, respectively. This consequently resulted in the weight reduction of the manufactured boat by $50 \%$. Recently, sugar palm fiber has been investigated as a hybrid reinforcement [154,156-159]. Certain precautions must be considered in the development of these novel natural fiber composites in terms of applicability. For instance, critical assessment and characterization of these composites for practical use in more comprehensive applications. Figure 3 presents the schematic diagram of layout segmentation and reinforcement layout of sugar palm/glass fiber designed by Nurazzi et al. [139] The results revealed improvements in thermal stability, char residue, as well as decomposition temperature as the glass fibers and sugar palm ratios, were raised to $50 / 50$ for both $30 \mathrm{wt} . \%$ and $40 \mathrm{wt} . \%$ of fiber loadings.

Afzaluddin et al. [160] investigated the influence of the different treatments with $2 \%$ silane (TSSP), $6 \%$ alkaline (TNSP), and a combination of $6 \%$ alkaline- $2 \%$ silane (TNSSP) on the thermal and physical characteristics of sugar palm/glass/thermoplastic polyurethane hybrid composites. The findings showed that the combined alkaline-silane-treated hybrid composites (TNSSP) displayed the minimum water absorption, thickness swelling, and density as with other hybrid composites. Besides this, good thermal stability was observed in the treated sugar palm fiber-based composites compared to the untreated ones. It is suggested that treated sugar palm/glass/thermoplastic polyurethane hybrid composites can fit automotive component applications. The results of this research are aligned with other studies conducted on the treated sugar palm fiber-reinforced polymer hybrid composites $[33,35,36,161]$. 


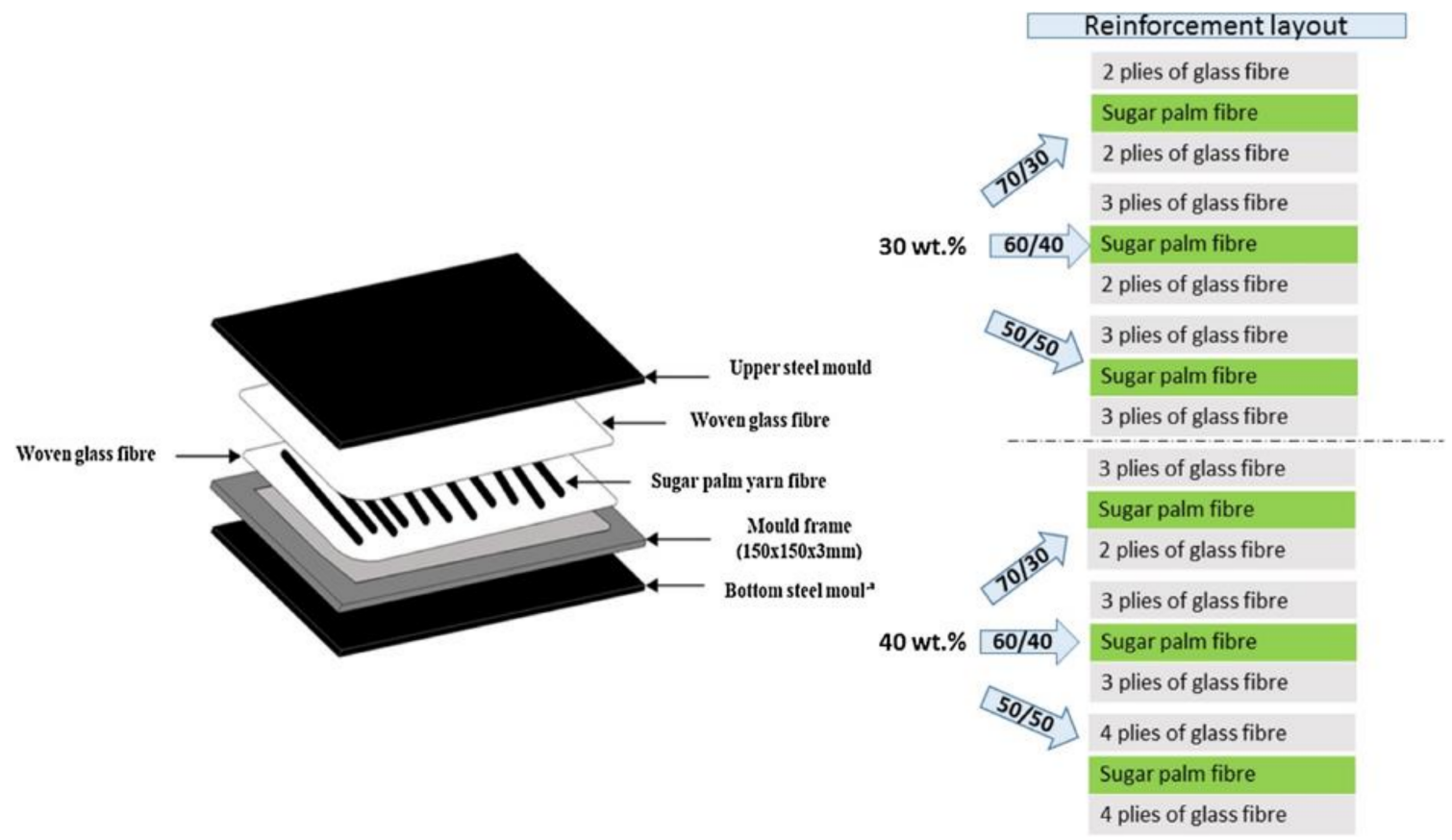

Figure 3. Schematic diagram of layup segmentation and reinforcement layout [139]. Extracted with permission from Elsevier.

\subsection{Kenaf Fiber Reinforced Hybrid Composites}

Kenaf (Hibiscus cannabinus L.) is among the most common natural fibers used as polymer matrix composite (PMC) reinforcement. It is an annual herbaceous plant that can be cultivated in a variety of climates and grows to more than $3 \mathrm{~m}$ in 3 months, even in temperate climates [162]. Davoodi et al. [48] replaced an automobile bumper beam with a hybrid kenaf/glass-reinforced epoxy composite to reduce environmental impact while maintaining the requisite strength.

The development of kenaf-glass (KG) fiber reinforced unsaturated polyester (UPE) hybrid composite was performed by Atiqah et al. [49] via the process of sheet molding compound for structural applications. The ratio of 70:30 (by volume) of UPE and KG fibers in a mat form is used using untreated and treated kenaf fiber. During the mercerisation process, the kenaf fiber was alkaline treated for $3 \mathrm{~h}$ using a $6 \%$ sodium hydroxide $(\mathrm{NaOH})$ diluted solution. Figure 4 shows the sequence of kenaf and glass fibers and matrix in between a mild steel mold for the fabrication of a hybrid composite. The result demonstrated that the highest tensile, flexural and impact strengths were attained from the treated kenaf containing 15/15 v/v KG fibers reinforced UPE hybrid composite. Besides this, the main fracture mode of composites observed under the scanning electron microscopy fractography was fiber debonding, cracking, and pull-out. Better interfacial bonding between the matrix was found in the kenaf treated 15/15 v/v KG reinforced hybrid composite than with other combinations. The hybridization of natural fibers, particularly synthetic and kenaf fibers, is an excellent method to improve the mechanical characteristics of the fabricated hybrid composite, as reported in many works [51-59,163].

The fabrication of kenaf fiber reinforced polypropylene (PP) sheets into a sheet form have been successfully carried out via thermoforming, where the optimum process is the compression molding that employs a layered sifting of a micro-fine PP powder and chopped kenaf fibers [164]. 30 and $40 \mathrm{wt}$.\% fiber contents provide sufficient reinforcement which improves the PP matrix's strength. The strength of the molded kenaf-PP composites was evidenced to possess better flexural and tensile strengths compared to the strength of other molded natural fiber composites, e.g., coir, kenaf, and sisal reinforced thermoplastics. The economic advantage of using kenaf composites over E-glass and other natural fibers is the possibility to analyze the elastic modulus data. The fabricated kenaf maleated PP 
composites exhibited a greater modulus/cost and an advanced specific modulus compared to coir, sisal, and E-glass. Therefore, they deliver a choice for substituting the currently used materials with a lower-cost alternative with a higher strength that is also environmentally friendly.

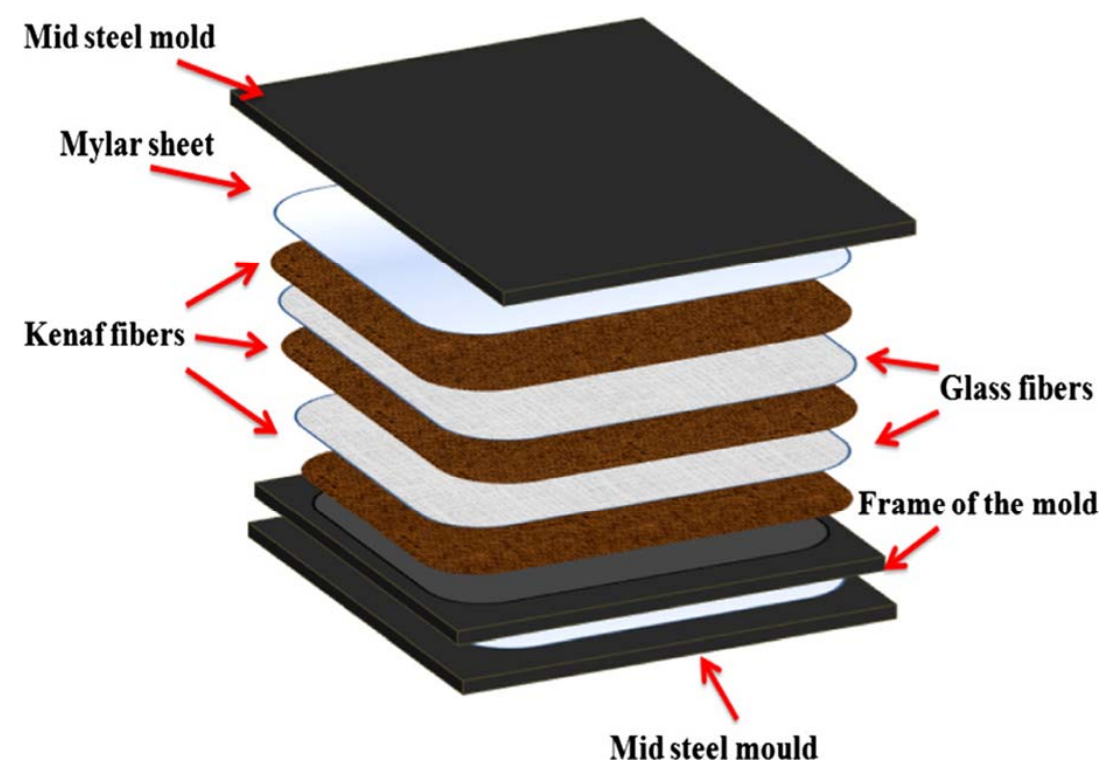

Figure 4. The sequence of kenaf and glass fibers and matrix in between mold for hybridization conducted by Atiqah et al. [48]. Extracted with permission from Elsevier.

The wood flour/kenaf fiber and PP hybrid composites were set to evaluate the hybrid outcome on the properties of the composites [67]. The findings demonstrated that nonhybrid composites (wood flour and kenaf fiber) revealed the lowest moduli compared with the hybrid composites; in addition, moduli of the hybrid composites strictly adhered with the relationship between the fiber reinforcement to wood filler. It was more likely to estimate the elastic modulus of composites using the hybrid mixtures equation rather than with the Halpin-Tsai equation. The influence of natural rubber toughening with polyester resin as the matrix on kenaf fibers were also studied by Bonnia et al. [165].

\subsection{Oil Palm Fiber Reinforced Hybrid Composites (OPRPC)}

Oil palm, Elaeis guineensis consist of two Arecaceae or palm family species. Oil palm empty fruit bunch fibers are among potential reinforcement fibers for polymer composites [166,167]. Agarwal et al. [167] examined the stress relaxation behavior in phenolformaldehyde resin reinforced with oil palm empty fruit bunch fibers and hybrid composites composed of oil palm fibers and glass fibers. The examination of the influences of fiber treatment, loading, strain level, and physical aging on the stress relaxation behavior and the calculation of the rate of relaxation at different time intervals were performed to describe the progressive alterations in the relaxation mechanisms [168].

Suriani et al. [69] introduced the oil palm empty fruit bunch (OPEFB) fiber and $\mathrm{Mg}(\mathrm{OH})_{2}$ into epoxy resin to obtain a hybrid composite, as shown in Figure 5. Four specimens were considered; (1) specimen A (blank, 0\% fiber), (2) specimen B (20\% fiber), (3) specimen C (35\% fiber), and (4) specimen D (50\% fiber). The used reinforcing and fire retarding additives were the PET yarn and magnesium hydroxide, respectively. The burning test result exhibited better flammability in specimen B, with the lowest average burning rate of $11.47 \mathrm{~mm} / \mathrm{min}$. Specimen A demonstrated the highest tensile strength of $10.79 \mathrm{~N} / \mathrm{mm}^{2}$. An SEM morphological test revealed rising surface defects by the rupture that resulted in the decline of the composites' tensile properties. The authors summarized that the tensile properties and flammability of OPEFB fiber-reinforced fire-retardant epoxy composites weakened with the increments in the fiber volume content at the optimum 
$20 \%$ loading of $11.47 \mathrm{~mm} / \mathrm{min}$ and $4.29 \mathrm{kPa}$, respectively. Another study conducted by Farah et al. [70] for the characterization of hybrid epoxy composites containing oil palm empty fruit bunch/woven kenaf fabric reinforcement demonstrated that the increased oil palm fiber content leads to an increase in the impact strength of the hybrid composite. It is described by the other circumstance in which randomly oriented empty fiber bunches (EFB) has a moderate interfacial interaction with epoxy that is vital to attaining a higher impact strength. An investigation into the impact of oil extraction, compounding processes and fiber loading [76], as well as matrix alteration on the mechanical characteristics of oil palm empty fruit bunch filled PP composites was also conducted [71]. Moreover, oil palm empty fruit bunch fiber/PP composites and oil palm-originated cellulose/PP composites were compared [169].

The effect of chemical alteration of the composites containing oil palm/phenol formaldehyde was studied by comparing polyester and epoxy matrices. In addition, the dielectric relaxation and the fiber orientation effect on the dynamic electrical properties of palm tree fiber-reinforced polyester composites were studied [69,170-172].

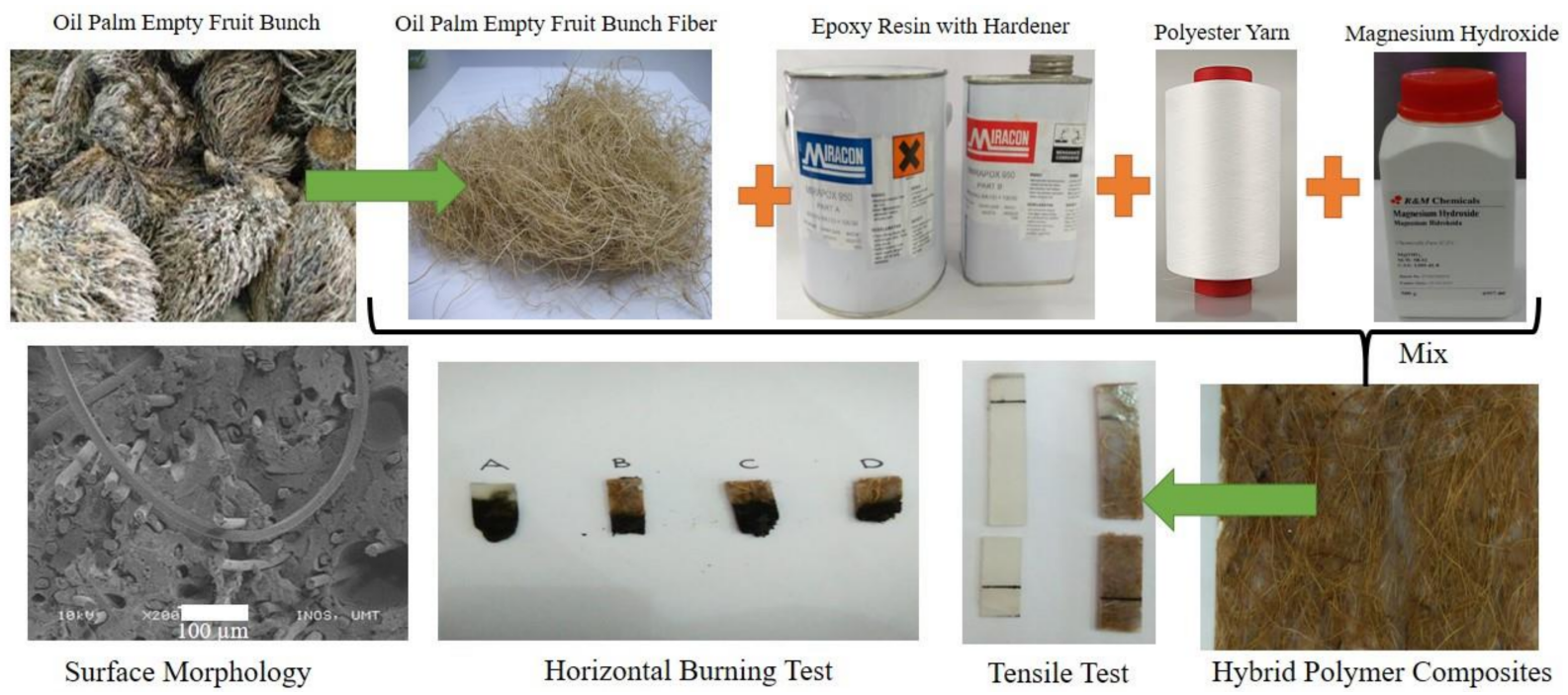

Figure 5. Extraction of OPEBF, and fabrication of OPEBF/polyester yarn, magnesium hydroxide reinforced epoxy resin hybrid composite. Extracted from [69] with permission.

\subsection{Pineapple Leaf Fiber Reinforced Hybrid Composites (PARPC)}

Pineapple-Ananas comosus - is a tropical plant native to Brazil, with long leaves containing fibers that have a high cellulose content. They are cheap and easily available. In addition, pineapple leaves possess the possibility to be used as a reinforcing agent in polymers. At present, pineapple leaf fibers are the by-products of pineapple farming, making these inexpensive fibers accessible for industrial use, especially for the reinforcement of polycarbonate to manufacture composites $[173,174]$. The composite fabricated from silane-treated pineapple leaf fibers revealed the most excellent impact and tensile strengths. Thermogravimetric analysis data demonstrated that the composites' thermal stability was poorer than neat polycarbonate resin, which also declined with the rising content of pineapple leaf fiber. The Transient Plane Source (TPS) technique was employed to study the thermal conductivity and diffusivity of phenol-formaldehyde composites reinforced with pineapple leaf fibers [175]. The composites' effective thermal diffusivity and conductivity were found to decrease compared to pure phenol-formaldehyde due to the increment in the fiber loading fraction.

Various efforts to improve pineapple leaf fiber's quality have been carried out via several surface alterations, e.g., alkali treatment, dewaxing, cyanoethylation, and grafting acrylonitrile onto dewaxed fibers [176]. The mechanical characteristics were optimum at $30 \mathrm{wt} . \%$ fiber loading. From all surface modifications, 10\% acrylonitrile grafted 
fiber-reinforced polyester composite exhibited a maximum tensile strength of $48.36 \mathrm{MPa}$. However, cyano-ethylated fiber composites demonstrated a better impact and flexural strengths of $27 \%$ and $41 \%$ more, respectively, compared to unmodified composite. The effect fiber content and surface treatment were also studied using natural rubber and PP as the matrices $[177,178]$.

Hashim et al. [77] conducted a study using a vacuum infusion technique on the influence of stacking sequence and ply orientation on the mechanical characteristics of pineapple leaf fiber (PALF)/Carbon hybrid laminate composites. The tensile and flexural tests' findings displayed that the laminate with inner carbon plies and ply orientation $\left[0^{\circ}, 90^{\circ}\right]$ resulted in the maximum tensile strength as well as modulus of $187.67 \mathrm{MPa}$ and $5.23 \mathrm{GPa}$, respectively. Fracture properties of the composite laminates were investigated using scanning electron microscopy and it was discovered that the failure was started at the weakest fiber layer. This phenomenon might be due to the failure modes, including delamination, debonding, matrix crack, fiber breaking, and fiber pull-out [179-186].

In a work conducted by Sathees Kumar et al. [82], the effects of fiber loading on the mechanical characteristics of reinforced polyester reinforced with sisal and pineapple leaf (PALF) fibers using an injection molding technique were studied, as shown in Figure 6. Figure 6 showed that equal weight \% share of PALF and sisal enhanced the overall mechanical attributes, e.g., ductile strength (207 MPa), bending strength (90.3 MPa), impact $\left(29 \mathrm{~J} / \mathrm{m}^{2}\right)$, and hardness (83.7). The mechanical test results revealed a regular trend of an increase in flexural, tensile, impact, and hardness with the addition of PALF fibers, and this was supported by various works $[80,81,187,188]$. Besides that, they concluded that this type of composite material could be valuable for multiple industries, including automotive and construction fields.

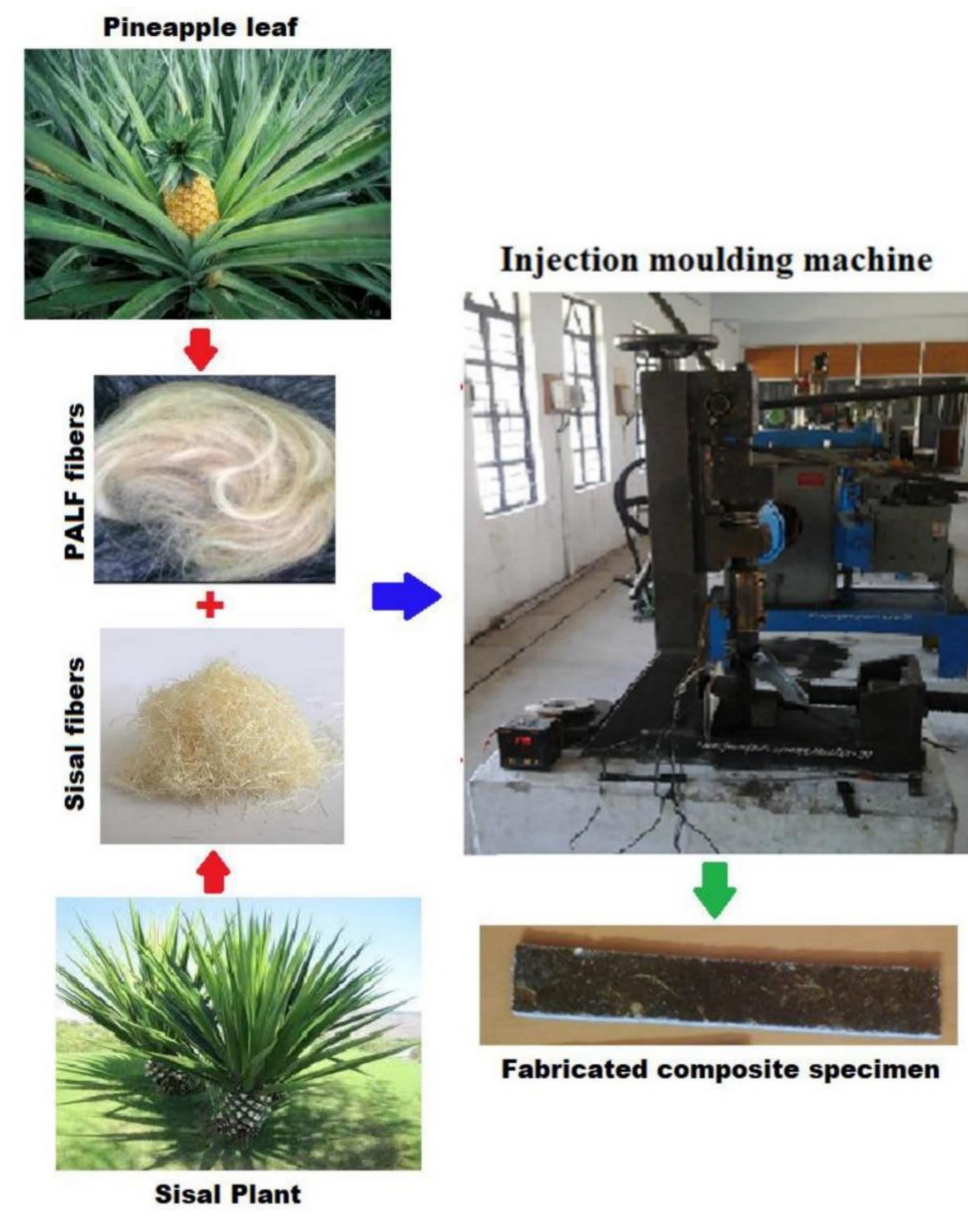

Figure 6. The fabrication process of pineapple leaf (PALF) and sisal fiber reinforced polyester composites using injection molding technique. Extracted from ref. [82] with permission. 


\subsection{Bamboo Fiber Reinforced Hybrid Composites (BRPC)}

Bamboo (Bambusa Shreb.) is a perennial plant that is able to reach a height of $40 \mathrm{~m}$ in monsoon climates. Figure 7 displays the morphological structure of the bamboo fiber [189]. Bamboo is used in carpentry, construction, plaiting, and weaving. Curtains are made from bamboo fiber and absorb various wavelengths of ultraviolet radiation, resulting in less harmful radiation to the human body.

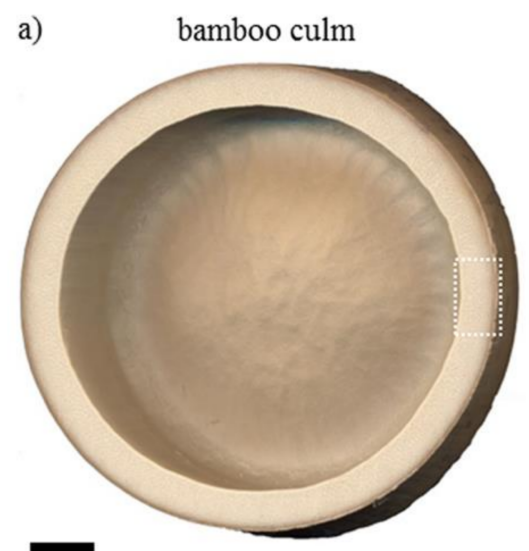

$\overline{10 \mathrm{~mm}}$ b) functionally-graded structure

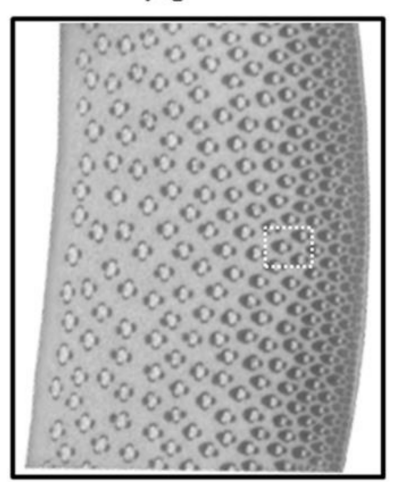

$1 \mathrm{~mm}$

e) hierarchical microstructure

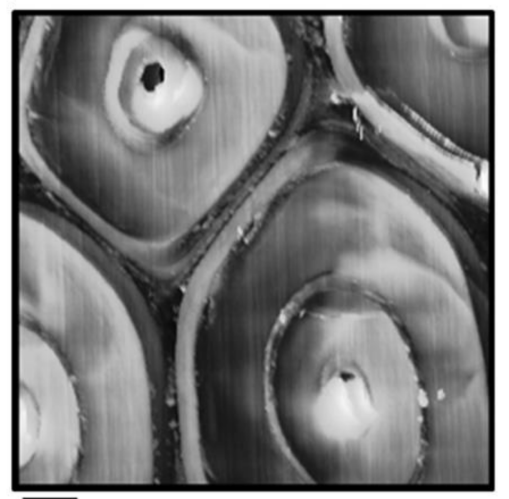

$1 \mu \mathrm{m}$ c) composite of fibres and parenchyma

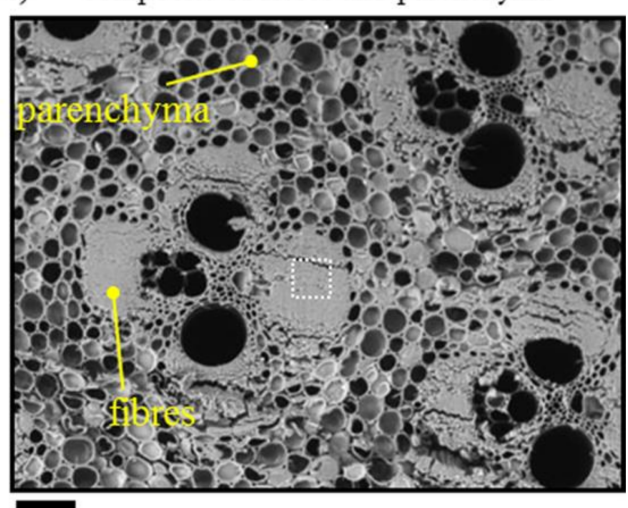

$\overline{100} \mu \mathrm{m}$

d)

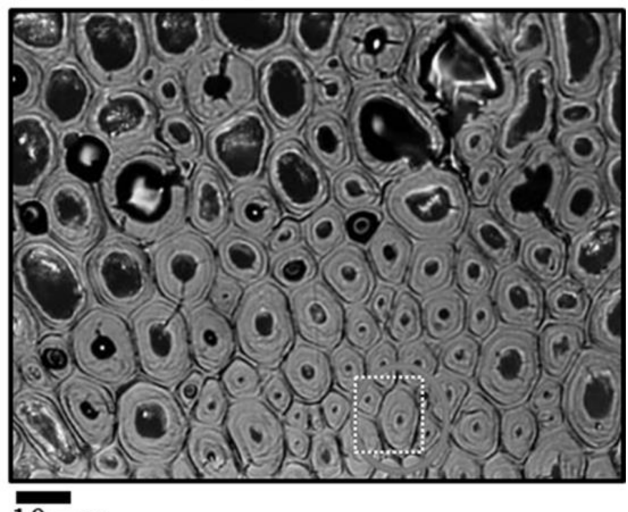

$10 \mu \mathrm{m}$

Figure 7. (a) Bamboo culm, (b) bamboo culm cross-section, (c) vascular bundle, (d) polylamellar cells, (e) microstructure fibers, and (f) bamboo's model of polylamellae structure. Extracted with permission from Ref. [189].

Osorio et al. [83] developed a novel mechanical extraction process of long bamboo fibers (Guadua angustifolia) for use as a reinforcing agent in structural composites. The effectiveness of the new reinforcement was evaluated by fabricating the composites containing unidirectional bamboo fiber/epoxy (BFC) with alkali-treated and untreated fibers. Two orientations of fiber (transverse and longitudinal) were employed in the flexural tests. When untreated fibers were utilized, the composite's longitudinal flexural strength was greater, whereas treatment increased the longitudinal flexural stiffness. For untreated bamboo in epoxy, the transverse strength rose with the decreasing alkali concentrations, while its three-point bending strength was already extremely high at approximately $33 \mathrm{MPa}$. They concluded that bamboo fiber offers a natural and renewable alternative to glass fiber and is helpful as traditional natural fiber reinforcement in a variety of applications where glass fiber and conventional natural fibers are already in use.

When preparing bamboo fiber-reinforced composites, characteristics of material and method affect the produced bamboo hybrid composite's quality [190]. A novel composite material fabricated from a right reinforcement material and the matrix combination is 
able to fulfill a specific application's requirements [191]. The benefits offered by composite materials include their excellent strength, their lightweight, and their moldability. In contrast, polymeric fiber composites have a high raw material cost. Numerous methods of fabrication have been developed to manufacture bamboo-reinforced plastics as well as hybrid composites, e.g., cold and hot presses, and injection molding. These procedures have been used on various bamboo-reinforced polymeric materials to make hybrid composites [84-87,192].

Bamboo fiber, aliphatic polyester, and polyolefin blends are particularly appealing. Blending bamboo fiber with polypropylene (PP) and polylactic acid (PLA) will lead to enhanced chemical, mechanical and thermal characteristics. The materials that result may be turned into products with more convenience and at a lower cost. The development of novel composites using a polypropylene (PP)/polylactic acid (PLA) matrix and filler bamboo fiber (BF) results in modifications in the raw thermoplastic's processability, morphology, and rheological characteristics [193]. Maleic anhydride grafted polypropylene (MAH-g-PP) was used at the filler-matrix interface to increase PP, PLA, and BF interface strength and to improve PLA dispersion and composite toughness. The addition of MAH-g-PP to composites resulted in positive morphological and rheological alterations, which were linked to enhanced PLA dispersion and increased bamboo fiber-matrix interactions.

Glass and bamboo fibers were used to create hybrid composites made of isophthalate polyester and vinyl ester resin. The optimized glass fiber reinforced composites were submitted to dynamical mechanical analysis to evaluate the dynamic characteristics as a function of temperature and frequency with 25,50 , and $75 \%$ of glass fibers substituted by bamboo fibers. The storage modulus $\mathrm{E}^{\prime}$ was spotted to drop as the wt.\% of bamboo fibers increased. The loss modulus was observed to reduce with loading; however, the damping property increased significantly. Fiber-matrix bonding was visible in scanning electron micrographs of composite flexural fracture surfaces.

\subsection{Jute Fiber Reinforced Hybrid Composites (JRPC)}

Jute is obtained from Corchorus genus plants that have about 100 species. At present, jute dominates the highest production volume among bast fibers and is globally available as one of the cheapest natural fibers. Jute is best grown in India, Bangladesh, and China. Figure 8 shows that jute plants are being cultivated for fiber production. Sarkar and Ray [94] studied the alkali-treated jute fiber reinforced with vinyl ester resin using the compression molding technique, as shown in Figure 9. The mechanical, dynamic, thermal, and impact fatigue behavior were compared with the untreated jute fiber-vinyl ester composites. Better fiber dispersion resulted from an extended alkali treatment that eliminated hemicelluloses, hence improving the crystallinity. All properties of mechanical, dynamic, thermal and impact were excellent due to the longer treatment period, concentration, and conditions during the alkali treatment [94].

Jute fiber reinforced hybrid composites have a number of advantages, e.g., a low specific gravity, increased tensile and compressive strength and modulus, and improved fatigue strength [194]. In work conducted by Prasath et al. [102], polyester-based polymer composites were developed by a compression molding technique with different stacking sequences of basalt and jute fabrics into the general-purpose polyester matrix. The result showed that a combination of pure basalt fiber maintained higher values during flexural and tensile tests. However, in the impact test, basalt fiber was somewhat lesser than jute fiber-reinforced composites [102]. 

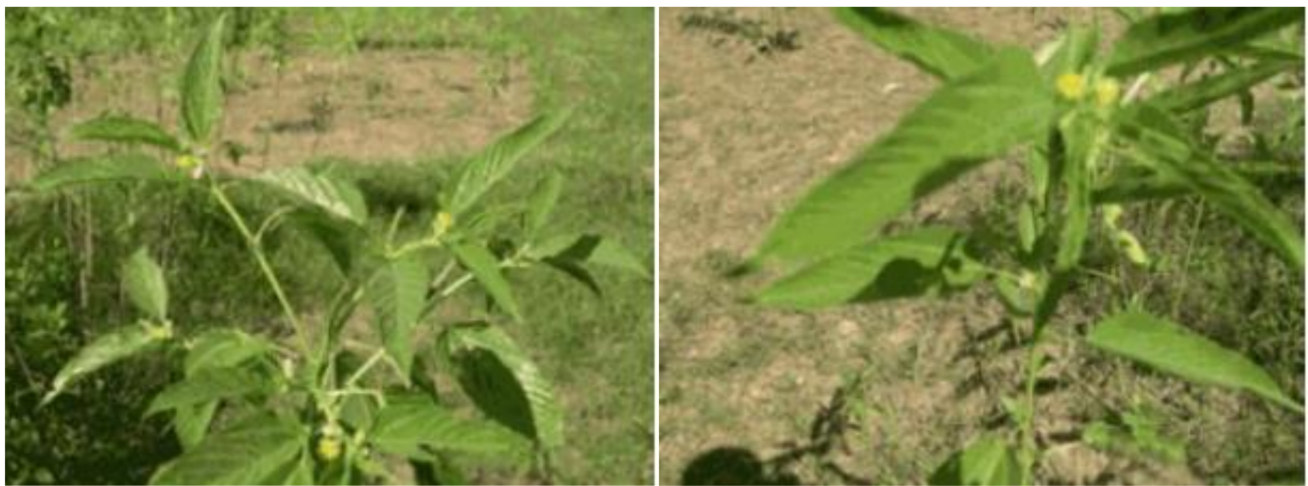

Figure 8. Jute plant. Reproduced with permission from Ramesh et al. [195].

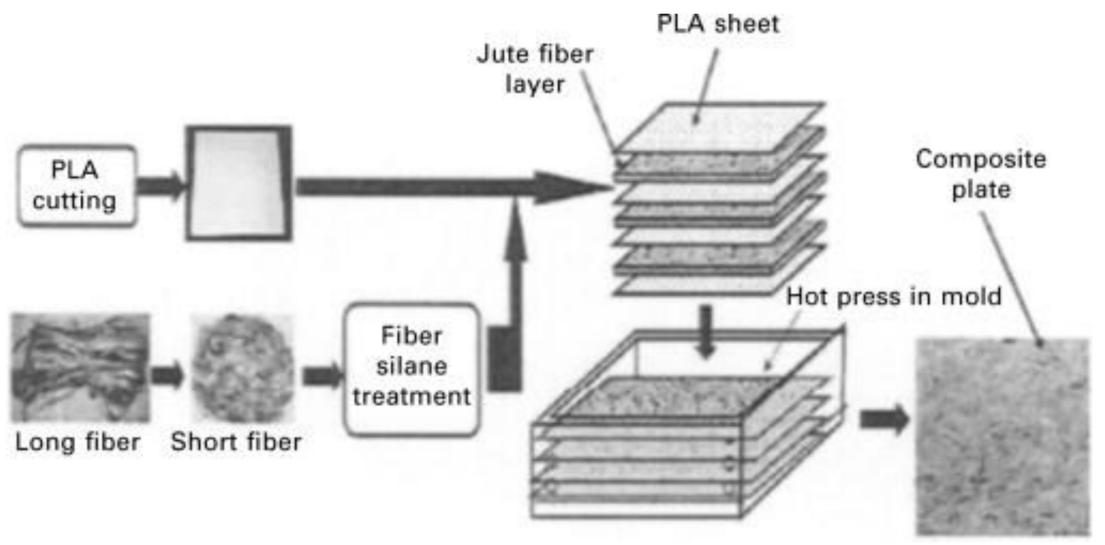

Figure 9. Fabrication procedure of jute fiber reinforced polymer composites [196]. Reproduced with permission.

Ramana and Ramprasad [95] conducted a study on a new hybrid composite developed from jute and carbon fiber reinforced epoxy composite and discussed its superiority or inferiority compared to jute-epoxy and carbon-epoxy composites so that the extent of the utility of the newly developed composite could be established. The hand layup technique was utilized for the composite preparation, and the total fiber content considered was $45 \%$. The newly developed composites, for instance, jute and carbon-epoxy hybrid composites, can replace carbon-epoxy composites without much loss of tensile and flexural strengths as well as a flexural modulus and with improved ductility and impact strength [95].

Mohanty et al. [197] studied the surface modification influence on the biodegradability and mechanical properties of jute/Biopol and jute/PA (Poly Amide) composites. More than $50 \%, 30 \%$, and $90 \%$ in tensile, bending, and impact strengths were found and compared to the values obtained for pure Biopol sheets. In addition, greater than $50 \%$ weight loss was observed after 150 days of compost burial of the jute/Biopol composites. The hybridization effects on tensile characteristics of jute-cotton woven fabric reinforced polyester composites were investigated as functions of fiber orientation, content, and texture of roving. Tensile characteristics along the alignment direction of jute roving (transverse to cotton roving alignment) rose continuously with fiber content until $50 \%$ before showing a tendency to decline. The composites' tensile strength value at $50 \%$ fiber content parallel to the jute roving was approximately $220 \%$ greater than pure polyester resin [101].

The evaluations conducted on jute fiber reinforced PP composites include a matrix modification effect, gamma radiation influence, interfacial adhesion effect on creep and dynamic mechanical behaviors, silane coupling agent influence, and natural rubber effect [198-201]. The jute/plastic composites properties were studied, comprising crystallinity, thermal stability, transesterification, modification, durability, weathering, eco-design of automotive components, fiber orientation on frictional and wear behaviors, 
and alkylation [198,202-207]. Jute fiber reinforced composites used polyester resin matrix, and examinations were carried out on the water absorption and dielectric behavior relationship [208], properties of elasticity, fracture criteria and notched strength [96], characterization of impact damage [209], thermal behavior and weathering [210], and silane treatment effect [211].

\subsection{Hemp Fiber Reinforced Hybrid Composites (HRPC)}

Hemp is another renowned bast fiber crop, an annual plant in the Cannabis family that cultivates in temperate climates. As a European Union subsidy for non-food agriculture, many current initiatives are progressing for its development in Europe. PP composites with hemp fibers were functionalized by the reactions of melt grafting using glycidyl methacrylate (GMA) and were manufactured via batch mixing [212]. The fibers and PP matrix modifications and various compatibilizer additions were conducted to enhance the interactions of the fiber-matrix. In comparison with the unaltered composite, chemical bonding between the fiber and the polymer (PP/Hemp) resulted in improved fiber distribution in the PP matrix as well as higher interfacial adhesion in the modified composite. Matrix and fiber modifications highly influenced the phase behavior and thermal stability of the composites. The alterations in the crystallization behavior and spherulitic morphology of PP in the composites were analyzed due to the hemp fibers' nucleating effect. Additionally, with increasing modified hemp content, a significant rise in the PP isothermal crystallization rate $\left(120-138^{\circ} \mathrm{C}\right)$ was observed. All composites demonstrated a higher tensile modulus (about $2.9 \mathrm{GPa}$ ) and lower elongation at break when compared to plain PP. Still, compatibilization with modified PP (10 phr) boosted the stiffness of the composites due to better fiber-matrix interfacial adhesion.

Ramesh et al. [103] fabricated hybrid composites using carbon, alkaline-treated, and untreated hemp fibers and investigated their properties. The hybrid composites possessed maximum tensile, flexural, impact, and shear strengths of $61.4 \mathrm{MPa}, 122.4 \mathrm{MPa}, 4.2 \mathrm{~J} / \mathrm{mm}^{2}$, and 25.5 MPa, respectively. In addition, from the composites' mechanical properties, the alkaline-treated composites exhibited better performance [103]. Thiagamani [104] fabricated hybrid bio-composites using the green epoxy matrix, reinforced with sisal (S) and hemp $(\mathrm{H})$ fiber mats via the cost-effective hand lay-up method and hot press employing different stacking sequences, as presented in Figure 10. As the stacking sequence was changed, the tensile strength varied slightly, where the intercalated arrangement (HSHS) hybrid composite demonstrated a maximum tensile modulus compared with the other hybrid counterparts. Hybrid composites (SHHS and HSSH) possessed a compressive strength that was $40 \%$ more than the other layering configurations, and the $\mathrm{HHHH}$ sample had the maximum ILSS of $4.08 \mathrm{MPa}$ [104].

$\mathrm{Li}$ and co-workers [213-215] investigated the effects of chelators, white rot fungi, and enzyme treatments towards hemp fiber separation from bundles and enhanced the hemp fibers' interfacial interaction with the PP matrix. The findings indicated that treated fiber composites had a greater interfacial shear strength than untreated fiber composites, a conclusion that was corroborated by a large body of literature [92,174,216-219]. This demonstrates that the white rot fungal treatment increased the interfacial attachment of hemp fiber to PP. Composites made of chelator concentrate treated hemp fibers exhibited the maximum tensile strength, measuring $42 \mathrm{MPa}$, a $19 \%$ improvement above composites made of untreated hemp fiber. Additionally, hemp fiber reinforced PP composites showed fascinating recyclability [220]. The findings demonstrated that despite the high number of reprocessing cycles, the mechanical properties of hemp fiber/PP composites were well maintained. Newtonian viscosity reduced as the number of cycles increased, indicating a decline in chain scissions and molecular weight caused by reprocessing. Another possible explanation for the decrease in viscosity was the shortening of the fibers during reprocessing. 


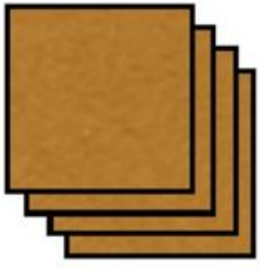

(a)

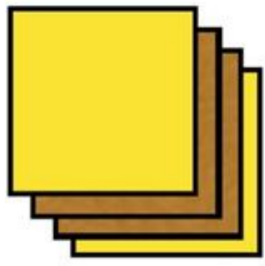

(d)

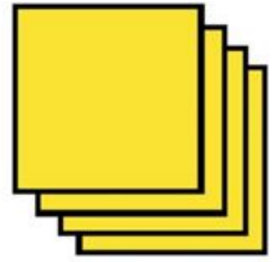

(b)

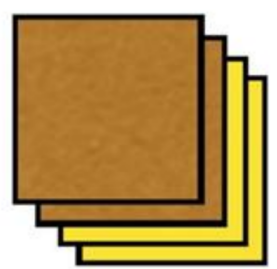

(e)

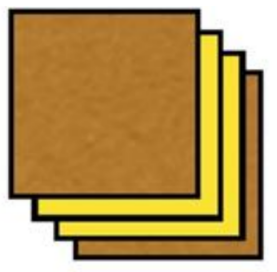

(c)

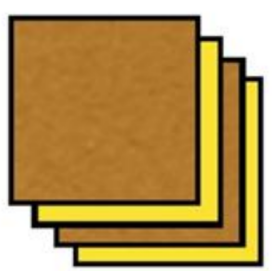

(f)

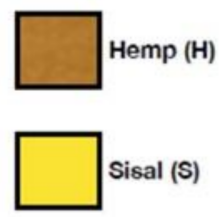

a - $\mathrm{HHHH}$

b - ssss

c- HSSH

d - SHHS

e- HHSS

f - HSHS

Figure 10. Different layering arrangements of sisal and hemp fiber mats [104]. Reproduced with permission.

In addition, several investigations on the hemp-based composites have also been conducted in terms of their effect on the falling weight impact properties [221], composites' properties and performances for curved pipes [222], impact load performance of resin transfer molded composites [223], composites' micromechanics [224], the influence of soybean oil and nano clay hybrid blends [105], as well as the practicality of untreated hemp as the biocomposites' fiber source [225]. Kunanopparat et al. [226] investigated the viability of using wheat gluten as a hemp fiber-reinforced composite matrix, focusing on the effect of thermal treatment and plasticization on mechanical properties.

\subsection{Flax Fiber Reinforced Hybrid Composites (FRPC)}

Flax is among the world's oldest fiber crops, containing bast fiber that is cultivated in temperate regions. Flax bast fiber is often utilized for applications in the higher value-added textile industries. Recently, flax has been broadly used in composites. The dynamic and static mechanical characteristics of nonwoven-based flax fiber reinforced PP composites were investigated while taking into account the effect of zein coupling agent, a zein protein [227]. It was discovered that composites containing zein protein as a coupling agent have improved mechanical properties. The composites' storage modulus increased with the addition of a zein coupling agent due to the increased interfacial adhesion. The diameter and position of flax fibers in the stems are used to evaluate their tensile mechanical properties. The substantial dispersion of these attributes is a result of the fiber's longitudinal axis size variation. The increased mechanical qualities of the fibers originating from the stem's center are related to their cell walls' chemical composition. The mechanical characteristics of unidirectional flax fiber/epoxy matrix composites were investigated in terms of their fiber content. The composites' properties were poorer than predicted from the characteristics of a single fiber.

Chaudhary et al. [100] developed and characterized the composites made from natural fibers (hemp/epoxy, jute/epoxy, flax/epoxy) and their hybrid composites (hemp/flax/epoxy, jute/hemp/epoxy, and jute/hemp/flax/epoxy). Among hemp/epoxy, jute/epoxy, and flax/epoxy, a higher hardness (98 Shore-D) and tensile strength (46.2 MPa) was shown by flax/epoxy composite. In contrast, better impact and flexural strengths were exhibited by jute/epoxy $\left(7.68 \mathrm{~kJ} / \mathrm{m}^{2}\right)$ and hemp/epoxy (85.59 MPa) composites, respectively. In general, hybrid composites exhibited better mechanical performance. For example, jute/hemp/flax/epoxy hybrid composite demonstrated the highest tensile modulus strength and sn impact strength of $1.88 \mathrm{GPa}, 58.59 \mathrm{MPa}$, and $10.19, \mathrm{~kJ} / \mathrm{m}^{2}$, respectively. In contrast, the flexural strength of jute/hemp/epoxy hybrid composite was maximum, 
86.6 MPa [100]. A similar trend has been shown by Fiore et al. [228], fabricating jute-basalt reinforced hybrid composites via the hand-lay-up method, as presented in Figure 11, for structural applications.

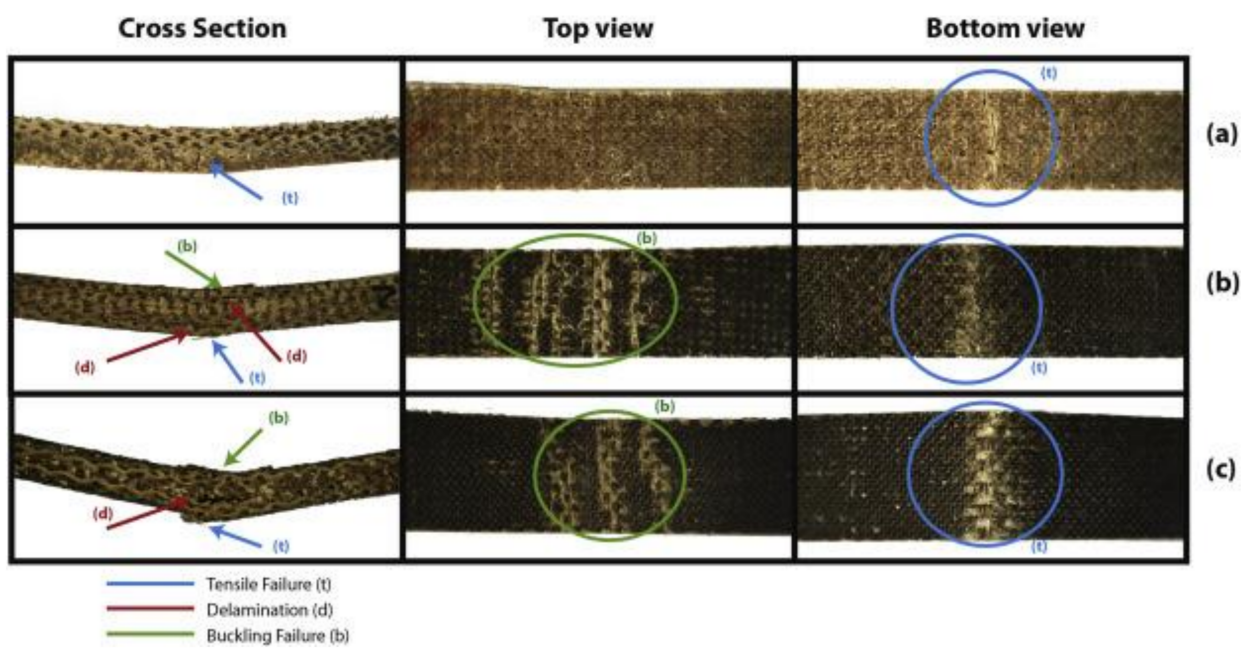

Figure 11. Jute-basalt reinforced hybrid composites including (a) jute fibre, (b) intercalate and (c) sandwich laminates [228]. Reproduced with permission, Elsevier.

Paturel and Dhakal [109] studied the moisture absorption influence on flax and flax/glass hybrid laminates to investigate their low-velocity impact behavior. Three different composite laminates, (1) flax fiber reinforced vinyl ester, (2) flax fiber hybridized glass fiber, and (3) glass fiber reinforced vinyl ester, were manufactured via the resin infusion method. Moisture immersion tests were conducted by immersing various specimens in seawater baths at room temperature and $70{ }^{\circ} \mathrm{C}$ at various periods of time. The low velocity falling weight impact test was conducted at a $25 \mathrm{~J}$ incident energy level, and the impact damage behavior was analyzed using scanning electron microscopy (SEM) and $X$-ray microcomputed tomography (micro CT) under both aging circumstances. With glass fiber hybridization, the percentage of moisture taken in by flax vinyl ester specimens was lowered. The maximum weight growth percentages for flax fiber, flax/glass hybrid, and glass fiber reinforced composites immersed in water at room temperature for $696 \mathrm{~h}$ were $3.97 \%, 1.93 \%$, and $0.431 \%$, respectively. When compared to a flax/vinyl ester composite without hybridization, the hybrid composite demonstrated increased load and energy, demonstrating that the hybrid system is a viable technique for improving the structural performance of natural fiber composites. At room temperature, the composites' moisture absorption behavior was found to follow Fickian behavior [109].

Numerous studies on the composites of flax fiber/polypropylene have been conducted. However, these researches concentrated on various variables, natural fiber thermoplastic mat (NMT) and glass fiber thermoplastic mat (GMT) comparison [229], the effect of glass fiber hybridization and fiber/matrix modification [230], the influence of fiber treatment on crystallization and thermal properties [110], surface treatment influence on the interface by thermoplastic starch, glycerol triacetate, boiled flax yarn, and -methacryl oxypropyl trimethoxy-silane [231], matrices comparison (PP and PLA) on the properties of composites [111], material and processing parameters effects [232], and processing methods influence [233]. Buttlar [234] reported the viability of flax fiber composite applications in the bus and automotive industries.

The bio-technical fiber modification effects are ascribed with: (i) toughness and fracture behavior, (ii) alkaline fiber treatment influence on unidirectional composites, and (iii) processing parameter influence on the successive flax fiber's decortication steps (retting, scotching, and hackling) towards the flax fiber reinforced epoxy composites [112,235-237]. Thermal degradation and fire resistance of flax fiber composites reinforced with polyester resin were studied, as well as the influence of chemical treatments on surface properties 
and adhesion, and also the influence of chemical treatments on the water absorption and mechanical characteristics $[238,239]$. Three soybean oil-based resins, methacrylic anhydride modified soybean oil, methacrylated soybean oil, and acetic anhydride modified soybean oil, were also used as matrices for the flax fiber-reinforced biocomposites.

\subsection{Ramie Fiber Reinforced Hybrid Composites (RRPC)}

Ramie is a plant from the Urticaceae (Boehmeria spp.) family that comprises approximately 100 species. The exploitation of ramie is for use as textile fiber with two limiting factors: production regions as well as a need for more considerable pre-treatment than other commercial bast fibers [240-243]. Ramie fiber/sugar palm fiber reinforced epoxy hybrid composites were manufactured using a combination of melt mixing and injection molding techniques as shown in Figure 12 [45]. Numerous ramie fiber/PP composites were manufactured by changing the fiber length, content, and pretreatment technique. Increments in fiber length and content were associated with significant increases in tensile, flexural, and compression strengths. Nonetheless, they negatively affected the elongation behavior and impact strength of composites. The preparation of thermoplastic biodegradable composites containing ramie fibers and a PLA/PCL matrix was carried out via in situ polymerization [116]. The influences of fiber content and length on the impact and tensile strengths of this biodegradable composite reinforced with natural fibers were studied along with the effect of a silane coupling agent towards improving interfacial adhesion. Tensile and impact strengths were found to be highest with the use of a silane coupling agent, ramie fiber length of 5-6 $\mathrm{mm}$, and $45 \mathrm{wt} . \%$ fiber content.

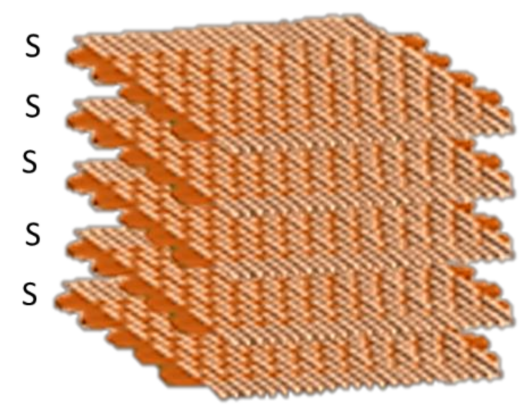

(a)

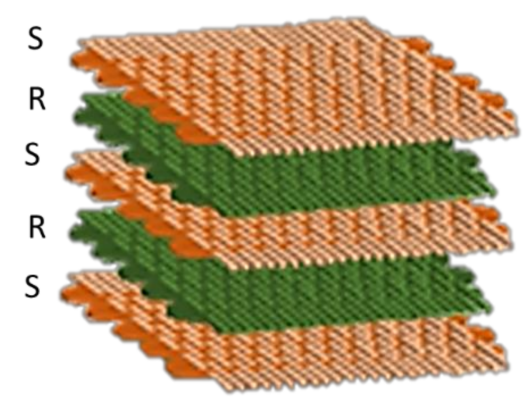

(c)

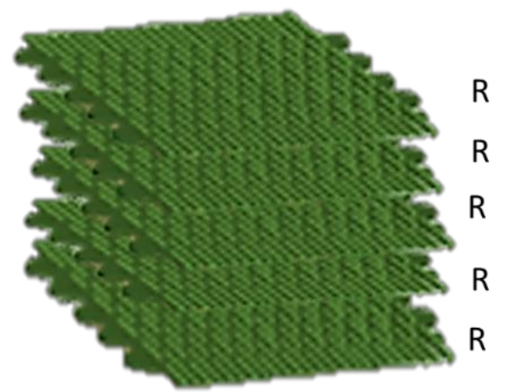

(b)

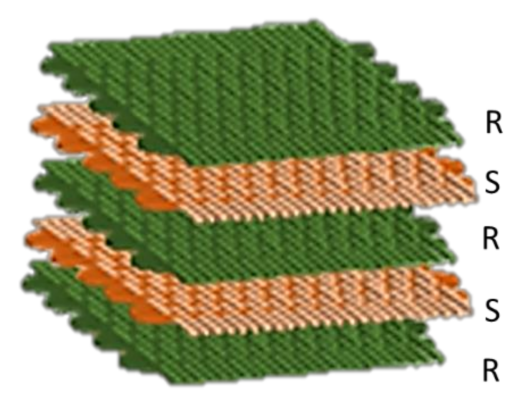

(d)

Figure 12. Various hybrid composite stacking sequences: (a) SSSSS, (b) RRRRR, (c) SRSRS, and (d) RSRSR [45]. Extracted from Ref. [45] with permission.

When compared to other natural fibers, the use of ramie fibers as reinforcement in hybrid composites is favored due to their superior mechanical qualities. Romanzini et al. [117] investigated the changes in chemical composition and thermal stability of ramie fibers post washing with distilled water. Apart from this, research on glass and washed ramie fiber composites was carried out, with an emphasis on the effects of using different fiber lengths $(25,35,45$, and $55 \mathrm{~mm})$ and the fiber compositions, while the fiber loading was set at $21 \mathrm{vol} . \%$. They reported that composites could be potentially produced from 
washed ramie fibers. The composite containing fiber length of $45 \mathrm{~mm}$ exhibited higher flexural strength despite the insignificant difference observed in lower volume fractions of glass fiber of 0:100 and 25:75. Better impact and flexural properties were also obtained from the increased glass fiber's relative volume fraction up to a limit of 75\% [117].

The major problem with employing natural fibers is that they are incompatible with a polymer matrix, which reduces the mechanical performance [244-247]. Tezara et al. [97] investigated the influence of stacking sequences, alkali treatment, and orientations of fiber on the mechanical characteristics of hybrid jute (J) and ramie (R) reinforced vinyl ester (VE) composites. First, woven fibers were made using three- and four-layer stacking sequences with a $0^{\circ}$ orientation. A higher tensile strength value of $298.90 \mathrm{MPa}$ was observed from the RJJR stacking sequence fabricated from different fiber orientations, e.g., $0^{\circ}, 30^{\circ}, 45^{\circ}$, and $90^{\circ}$. This was done to study the influence of fiber orientation on the flexural and tensile characteristics. $0^{\circ}$ fiber orientation possessed significantly flexural and tensile strengths compared with other orientations of $28.90 \mathrm{MPa}$ and $66.81 \mathrm{MPa}$, correspondingly. Enhancement of mechanical properties was also conducted via $5 \mathrm{wt} . \%$ and $10 \mathrm{wt} . \%$ alkali treatments, resulting in a maximum flexural strength $(34.50 \%)$ increment in $0^{\circ} \mathrm{RJJR}$ with $5 \mathrm{wt} . \%$ compared with the untreated RJJR. They concluded that the fiber orientation and a lower alkali treatment concentration ( $5 \mathrm{wt} . \%$ ) combination had significantly improved the mechanical characteristics of fiber hybrid composites.

Hand lay-up method employing epoxy as a matrix is used to manufacture bulletproof panels, where the prototype is more lightweight and economical compared to the conventional ones made of steel-based materials, Kevlar/aramid composite, and ceramic plates used in military antiballistic equipment [118]. The findings from bullet testing revealed the panels' ability to resist high-impact projectile (level II) penetration and resulted in minimal fractures. However, level IV ballistic testing demonstrated the failure of all prototype panels to resist the projectile's high-impact velocity. From the tests, ramie fiber has enough breaking strength and toughness to pass level II bullet testing. Among the matrices used to reinforce ramie fiber are included polyester [119], epoxy-bioresin [248], soy protein [249], epoxy [250] and PP [251].

\subsection{Abaca/Banana Fiber Reinforced Hybrid Composites (ARPC)}

The banana plant produces abaca/banana fiber, the strongest commercially available cellulose fiber, which is strong and seawater-resistant. Abaca is a native of the Philippines, where it is currently grown, as well as in Ecuador, and was then the most chosen rope fiber in marine applications.

Bledzki et al. [120] studied the mechanical characteristics of abaca fiber reinforced PP composites with varying fiber lengths $(5,25$, and $40 \mathrm{~mm})$ and compounding procedures (mixer-injection, mixer compression, and direct compression moldings). When the length of the fibers was increased from 5 to $40 \mathrm{~mm}$, the tensile and flexural characteristics were increased slightly, but not significantly. The mixer-injection molding technique outperformed the other two compounding procedures in mechanical performance (tensile strength was roughly $90 \%$ greater). The comparison of the composites of abaca fiber PP with the composites of jute and flax fiber PP revealed that the best falling weight impact properties and notched Charpy (Figure 13) were possessed by abaca fiber composites. Figure 14 shows the higher odor concentration of abaca fiber composites compared to flax and jute fiber composites.

The effects of fiber loading, frequency, and temperature on the polarity of banana fiber reinforced polyester composites were studied in a dynamic mechanical analysis [252]. The composites' storage modulus at $40 \%$ fiber loading was the greatest, showing that the inclusion of abaca fiber in the polyester matrix resulted in reinforcing effects at higher temperatures. Enhanced fiber and matrix interactions were confirmed by the increased dynamic modulus and low damping values. Abaca fibers were reinforced with the matrices of cement [121], polyurethane [253], aliphatic polyester resin [254], PP [122,255], 
urea-formaldehyde [256], PE [123,124], polyester [125,126], and polyvinyl alcohol [127] to evaluate the properties of the produced composites.

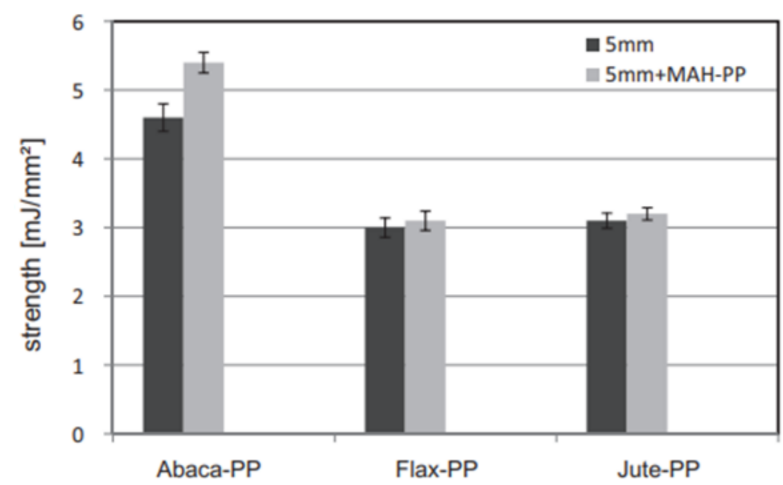

Figure 13. Notch Charpy strength of abaca/jute/flax fiber-PP composites comparison with and without MAH-PP. Reprinted with permission, Elsevier.

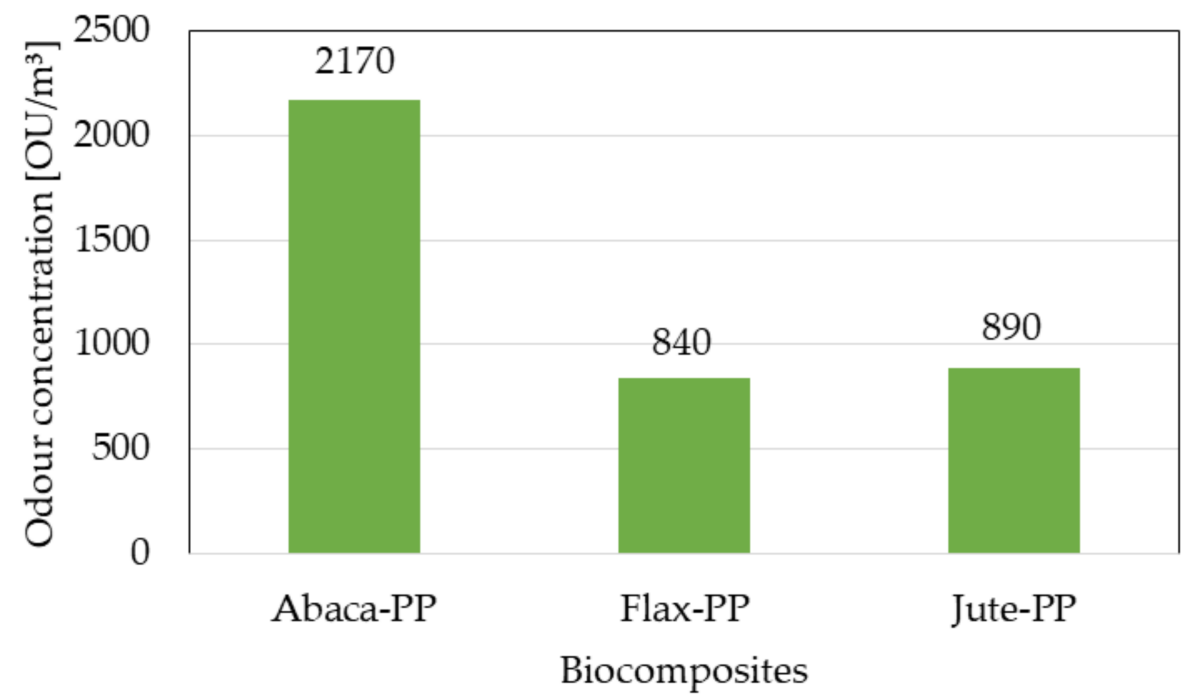

Figure 14. Comparison of odor emission concentration abaca/jute/flax fiber-PP composites. Reprinted with permission, Elsevier.

\subsection{Sisal Fiber Reinforced Hybrid Composites (SRPC)}

Sisal is a type of agave (Agave sisalana) mostly grown in Brazil and East Africa. Between 1998 and 2010, global demand for sisal fibers and products was predicted to fall by $2.3 \%$ each year. Synthetic replacements and harvesting systems adoption that use less or no twine continued to undercut the conventional market for fibers. Sisal fiber will be used to make a wide range of non-structural and structural industrial goods using various polymer matrices.

The composites' mechanical properties are heavily impacted by the bonding between the fiber and matrix, as reported by Senthilkumar et al. [257] and Ilyas et al. [258]. Good interfacial bonding induces transfer of the applied stress by the reinforced polymer composites to fibers. The hydrophilicity and hydrophobicity of the fibers and resin, respectively, usually result in poor bonding of the plant-based fibers that could be overcome via mechanical interlocking, chemical, inter-diffusion and electrostatic bondings, chemical pretreatment, as well as coupling agent [259]. Compression molding (CM), resin transfer molding (RTM), and injection molding are among the common techniques of natural fiber composite fabrication [260-262]. These methods differ from each other in terms of processing temperature, pressure, and speed. Sreekumar [263] studied the mechanical properties of the fabricated sisal fiber polyester composites via resin transfer and compression moldings. The RTM 
composites demonstrated a higher Young's modulus, tensile and tensile flexural strengths, and flexural modulus. CM composites, on the other hand, possessed more water absorption and voids due to the weaker adhesion of fiber-matrix compared to RTM composites.

Getu et al. [91] reported that composite materials possessed a low density with a high strength to weight ratio, stiffness to weight, strength ratios, and fatigue strength to weight ratio than conventional engineering materials, allowing them to be used in wide structural constructions applications. Lightweight natural fibers produce lightweight composite materials that in automotive applications improve fuel economy by minimizing harmful emissions. As shown in Figure 15, Getu et al. [91] prepared and characterized the performance of sisal and bamboo reinforced polyester hybrid composite (BSFRHC) with various sisal and unidirectional (UD) bamboo fiber orientations. Following that, BSFRHC was developed with a total fiber volume percentage of $20 \%$ via hand lay-up method using 3:1 bamboo to sisal fibers ratio prior to compressive, tensile, flexural and impact tests. It was concluded that varying fiber orientation resulted in variation in tensile strength; a higher tensile strength was found in the composite of bamboo/sisal fiber with $0^{\circ}$ fiber orientation. The $0^{\circ}$ fiber orientation composite demonstrated a higher compressive strength than the $90^{\circ}$ fiber orientation composite and the bidirectional $\left(0^{\circ} / 90^{\circ}\right)$ fiber orientation composite. Higher tensile and flexural strengths were observed in the unidirectional $90^{\circ}$ fiber orientation, whereas almost similar tensile strengths were obtained from the unidirectional $90^{\circ}$ and bidirectional $\left(0^{\circ} / 90^{\circ}\right)$, and bidirectional $\left(0^{\circ} / 90^{\circ}\right)$ possesses higher flexural strength compared to unidirectional $90^{\circ}$ fiber orientation. ANSYS Software was used to carry out the impact analysis of BSFRHC based vehicle internal door panel and the potential for the applications of interior automotive parts was revealed from the composites of sisal and bamboo fibers in unidirectional $0^{\circ}$.

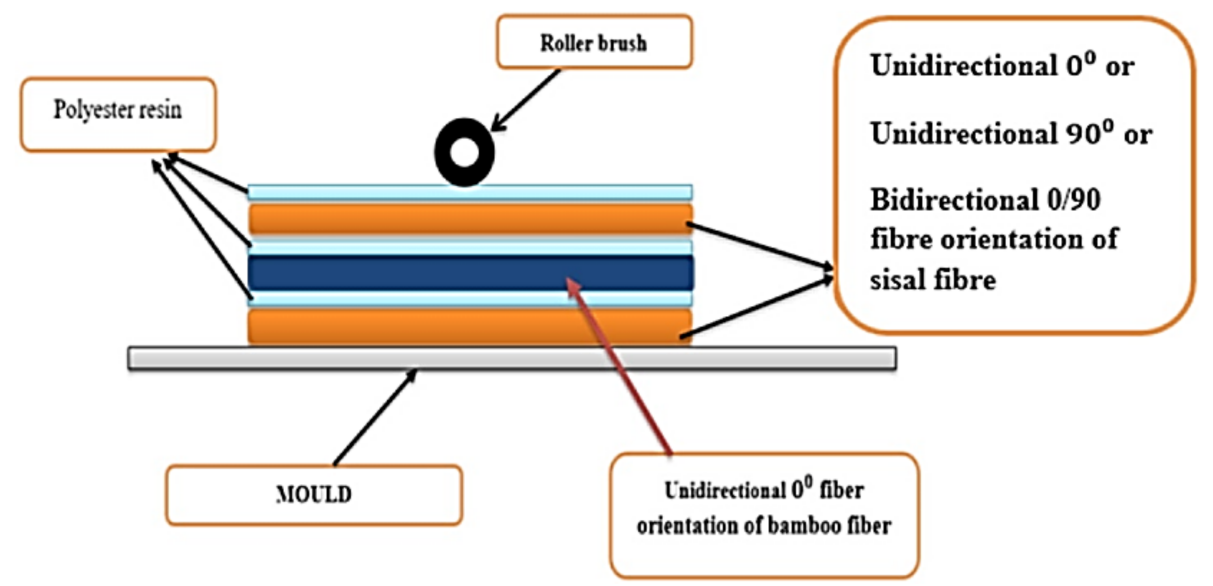

Figure 15. Fabrication of composite with varied orientations of sisal fiber [91]. Reprinted with permission, Elsevier.

Asaithambi et al. [129] conducted a study on the effect of Benzoyl Peroxide (BP) fiber surface treatment towards the mechanical characteristics of banana/sisal fiber (BSF) reinforced PLA composites [129]. BSF underwent BP treatment for the purpose of improving fiber and matrix adhesion. Twin-screw extrusion of BSF (30 wt.\%) reinforced PLA (70 wt.\%) hybrid composites was performed, followed by injection molding. The findings revealed that treated BSF possessed better bonding and wettability, resulting in the PLA matrix's restricted motion. When comparing the composites of BSF-reinforced PLA with untreated BSF reinforced PLA and virgin PLA, the mechanical characteristics, e.g., flexural and tensile moduli, were improved.

Noorunnisa Khanam et al. [130] investigated the fluctuation of mechanical characteristics, e.g., flexural and tensile properties of the hybrid composites comprising randomly oriented unsaturated polyester-based sisal/carbon fibers varying fiber weight ratios by the hand lay-up approach. These hybrid composites were tested for chemical resistance to 
different solvents, acids, and alkalis. The influence of treating sisal fibers with $\mathrm{NaOH}$ on the tensile, flexural, and chemical resistance characteristics of these sisal/carbon hybrid composites was also investigated. The flexural and tensile characteristics of the hybrid composites were improved with the rising loading of carbon fiber, where the tensile and flexural characteristics of these hybrid composites were found to be superior to those of the matrix. Alkali treatment resulted in significant improvements in the tensile and flexural characteristics of the sisal/carbon hybrid composites. All compounds, excluding carbon tetrachloride, were resistant to these untreated and alkali-treated hybrid composites in chemical resistance tests.

Incorporation of zinc borate and magnesium hydroxide into sisal/PP composites as flame retardants was performed to improve the composites' thermal stability as well as to reduce the composites' burning rate [264]. The same study reported no synergistic effect from incorporating magnesium hydroxide and zinc borate into sisal/PP composites. Furthermore, at high shear rates, the sisal/PP composites showed substantial changes in shear viscosity, showing that the flame retardants utilized in this investigation did not affect the composites' processability. The sisal/PP composites that had flame retardants added to them had tensile and flexural properties comparable to those of the sisal/PP composites without flame retardants.

Environmental impacts of degradation behavior [265], coupling agent influence on abrasive wear qualities, and the ageing effect [266] on mechanical characteristics have all been examined with sisal/PP composites. All plant fiber composites were developed by Zhang et al. [267] by transforming wood flour using a proper benzylation procedure and compounding of both discontinuous and continuous sisal fibers to create composites from renewable resources. The developed sisal/plasticized wood flour composites were found to be fully biodegradable from the degradation tests. The process of decomposition was accelerated by taking into account both lignin and cellulose in the composites. When it comes to practical applications, composites' hydrophobicity and flame resistance are vital; therefore, molecular modification and/or integration of inorganic additives are appropriate approaches as long as the composite's biodegradability is not compromised.

Many studies were performed on the composites of sisal fiber reinforced polyester concerning their characteristics of moisture absorption [268], as well as treatment of fiber with admicellar [269]. A few investigations were conducted on the composites of sisal fiber-reinforced phenolic resin, e.g., chemical alteration of such with lignins [270], hydroxylterminated polybutadiene rubber modification [271], cure cycles effect [272], employing glyoxal from natural resources [272], and alkali treatment effect [273]. Nevertheless, epoxy resin was employed as a matrix for sisal fiber-reinforced composites, and the effects of fiber orientation on electrical characteristics [274] and reinforcing degree [275] were investigated. A different matrix (cement) was also used in the sisal fiber-reinforced composites to study their cracking micro-mechanisms [276] and the influence of accelerated carbonation on cementitious roofing [277].

Towo et al. [278] prepared composites using treated sisal fibers with epoxy and polyester resin matrices. Dynamic thermal analysis and fatigue evaluation tests were conducted on the produced composites and revealed better mechanical characteristics in alkali-treated fiber bundle composites than untreated fiber bundle composites. The polyester resin matrices were most affected by alkali treatment, where improvements in the composites' fatigue lives were found for the alkali-treated sisal fiber bundles. The superiority of alkali-treated fiber composites was analyzed and was associated with low cycle fatigue. Epoxy matrix composites possessed a longer fatigue life than polyester matrix composites. The chemical treatment had significantly and positively impacted the fatigue life of polyester matrix composites; however, it demonstrated a lesser effect on epoxy matrix composites. Studies on sisal fibers were also conducted with other matrices, e.g., rubber [279], phenol-formaldehyde [256], cellulose acetate [280], bio polyurethane [281], and polyethylene [282] in terms of their morphological, mechanical, cure, and chemical properties. 


\section{Mechanical Properties of NF Reinforcement Hybrid Composites}

Researchers have been focusing their research interests on composites of natural fibers, e.g., biocomposites made of natural or synthetic resins reinforced by natural fibers. Natural fibers have numerous advantages, including their low density, which results in comparatively lightweight composites having excellent specific properties $[244,283,284]$. Additionally, these fibers offer significant cost savings and ease of processing, as well as being a highly renewable resource, thereby reducing reliance on domestic and foreign petroleum oil. Researchers have reviewed recent advances in natural fiber (e.g., flax, hemp, jute, kenaf, straw, bamboo, and coir) applications in composites $[8,285,286]$. Nilza et al. [287] designed and manufactured composites from three Jamaican natural cellulosic fiber: sugar cane bagasse, banana trunk, and coconut husk coir. The prepared samples were tested for carbon and ash contents, moisture content, water absorption, elemental and chemical analyses, and tensile strength.

\subsection{Tensile Properties}

Natural fiber-reinforced composites possess similar mechanical characteristics to synthetic fibers, as reported by Van De Velde and Kiekens [288] for hemp, flax, sisal, and jute fibers, in terms of strength and modulus compared to glass fiber. Srinivasan et al. [289] researched the ultimate tensile strength of the composites of glass fiber and banana/flax reinforced polymer (GFRP). A higher ultimate tensile strength $\left(39 \mathrm{~N} / \mathrm{mm}^{2}\right)$ was observed in the flax banana-GFRP hybrid composite compared to the banana-GFRP and flax-GFRP composites with $30 \mathrm{~N} / \mathrm{mm}^{2}$ and $32 \mathrm{~N} / \mathrm{mm}^{2}$, respectively. Paul et al. revealed the mechanical characteristics of the composites of kenaf reinforced polypropylene showing improvements in ultimate tensile stress and tensile modulus with a rising fraction of fiber weight [23]. Table 3 displays the tensile properties comparison of different natural fibers with synthetic fibers.

Table 3. Tensile properties of natural and inorganic fibers.

\begin{tabular}{|c|c|c|c|c|c|c|}
\hline Fibers & $\begin{array}{l}\text { Density } \\
\left(\mathrm{kg} / \mathrm{m}^{3}\right)\end{array}$ & Diameter $(\mu \mathrm{m})$ & $\begin{array}{c}\text { Tensile } \\
\text { Strength (MPa) }\end{array}$ & $\begin{array}{l}\text { Tensile Modulus } \\
\text { (GPa) }\end{array}$ & $\%$ Elongation & Ref. \\
\hline Sugar Palm & 1290 & 99-311 & 190.29 & 3.69 & 19.6 & [157] \\
\hline Jute & 1460 & - & $393-800$ & $10-30$ & $1.5-1.8$ & [290] \\
\hline Sisal & 1450 & $50-300$ & $227-400$ & $9-20$ & 2-14 & [290] \\
\hline Kenaf & 1400 & 81 & 250 & 4.3 & - & [290] \\
\hline Flax & 1500 & - & $345-1500$ & $27.6-80$ & $1.2-2.3$ & [291] \\
\hline Hemp & 1480 & - & $550-900$ & 70 & 1.6 & [291] \\
\hline Banana & 1350 & $80-250$ & $529-759$ & 8.20 & $1-3.5$ & [292] \\
\hline Coir & 1150 & $100-460$ & $108-252$ & $4-6$ & $15-40$ & [292] \\
\hline Bamboo & 910 & - & 503 & 35.91 & 1.4 & [292] \\
\hline Cotton & 1600 & - & $287-597$ & $5.5-12.6$ & $3-10$ & [293] \\
\hline E-glass & 2550 & $<17$ & 3400 & 73 & 3.4 & [294] \\
\hline S-glass & 2500 & - & 4580 & 85 & 4.6 & [294] \\
\hline Carbon (Std. PAN-based) & 1400 & - & 4000 & $230-240$ & $1.4-1.8$ & [294] \\
\hline
\end{tabular}

\subsection{Flexural Properties}

The potential of composite materials' use in structural applications is determined via a few parameters. Major strength is the flexural properties that include flexural strength, modulus, and load as well as deflection at the break. Flexural strength is related to the fiber content/fiber length, as reported in a few studies. Satyanarayana et al. [293] demonstrated that improvements in toughness and ductility of bamboo-mesh reinforced cement composites as well as significant enhancements in the tensile, flexural, and impact strengths. Banana and glass fibers were fabricated at different fiber lengths and loadings in the phenol-formaldehyde composites, and the mechanical properties were compared. From the composites of flexural property analysis, the optimum length of fiber needed 
for banana and glass fibers was different from the phenol-formaldehyde resole matrix reinforcement [295]. Aziz et al. observed the influence of random and long kenaf and hemp fibers alkalization and alignment on the formed composite fabricated via a combination of the fibers with polyester resin hot-pressed [296]. Long and alkalized fiber composites exhibited higher flexural strength and modulus compared with the as-received fiber composites. The decline in the flexural properties was due to water absorption that damaged and degraded fiber-matrix interfacial bonding; however, the maximum strain was simultaneously increased [297-299].

Shibata and team reported that the densified structure of kenaf fibers contributes to their composites' higher flexural strength compared to the porous bagasse fibers [300]. Other researchers studied the effect of hybridizing the composites of jute/glass-reinforced epoxy on their mechanical properties. The E-glass fabric layers added to the composites' outer layers revealed improvements in the properties of bending, tensile, and impact of the jute-reinforced composites [98]. A summary of specific moduli of natural and glass fibers is presented in Figure 16.

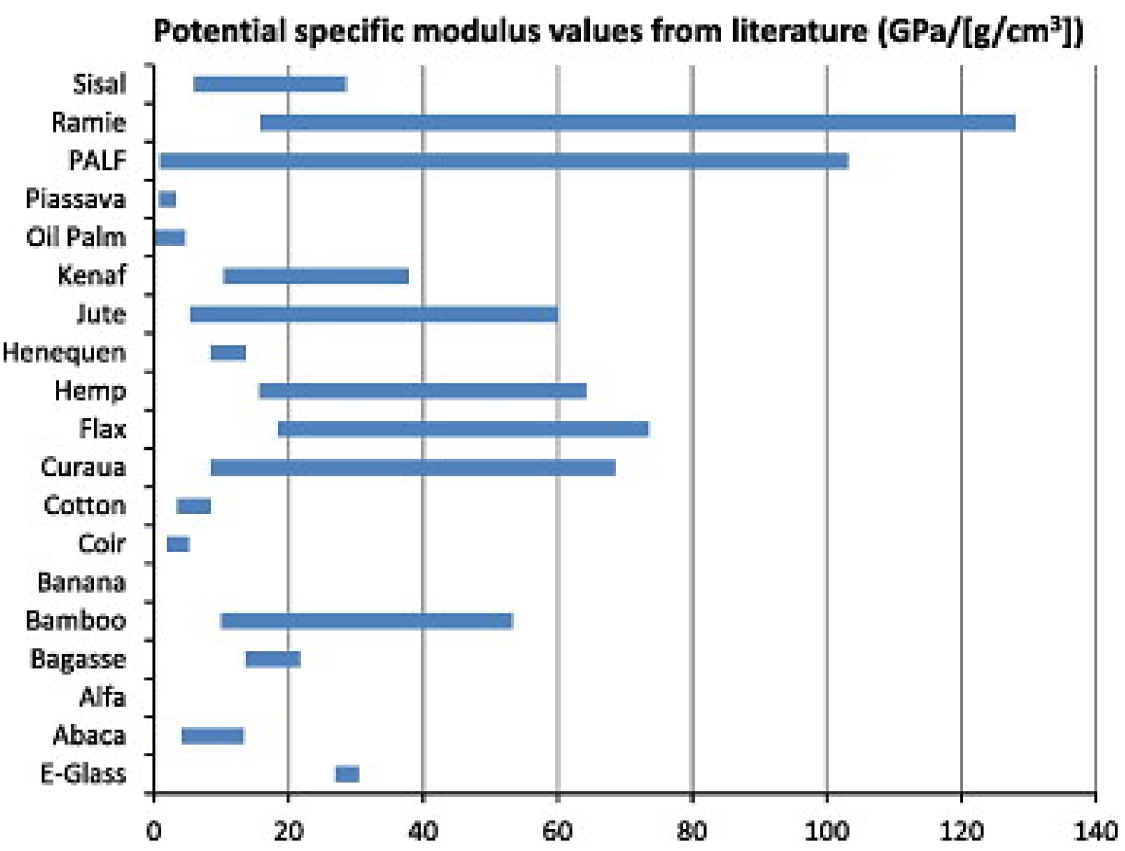

Figure 16. Comparison of values and ranges of potential specific modulus between natural and glass fibers [299]. Extracted with permission from Elsevier.

\subsection{Impact Properties}

Pothan et al. [301] examined the composites prepared from short banana fiber reinforced polyester, with the aim of studying the influence of fiber lengths and content on the composites' impact strength. A $40 \mathrm{~mm}$ fiber length yielded the highest impact strength, while $40 \%$ incorporation of untreated fibers resulted in a $34 \%$ improvement of impact strength. Another study on the impact behavior of 35\% jute/vinyl ester composites reinforced with alkali-treated and untreated fibers revealed hemicellulose removal, improving the crystallinity and, consequently, better fiber distribution [302]. Sanjay et al. [303] compared different compositions of laminates to investigate the impact behavior of the composites' banana/E-glass fabrics reinforced polyester hybrid and found $6 \mathrm{~J}$ impact strength in the hybrid laminate, which was the highest value attained.

\subsection{Hardness Properties}

Zampaloni et al. [304] discussed the excellent potential of the current materials substitute by the Kenaf-maleated polypropylene composites that demonstrated more efficient modulus/cost as well as better specific strength and modulus at a cheaper cost compared 
to the materials reinforced with E-glass, coir, and sisal (Figure 17). The hardness of various laminates fabricated from hybrid composites of banana/E-glass fabrics reinforced polyester utilizing different stacking sequences was measured by Sanjay et al. [303] Laminate L1, or the composite of pure glass fiber, possessed the hardness of $26.72 \mathrm{HV}$, while laminate L2 (composites of pure banana fiber) exhibited the poorest hardness of $12.36 \mathrm{HV}$.

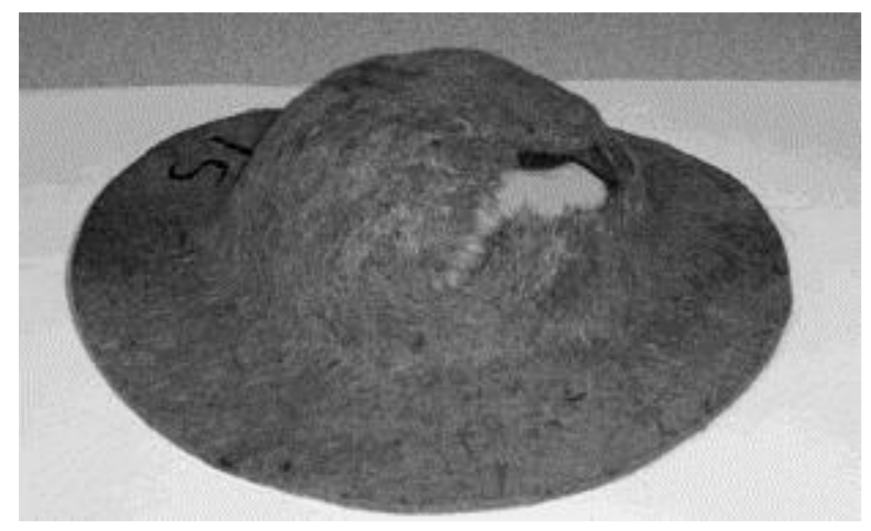

Figure 17. Kenaf-PP/MAPP composite hybrid composites tested for hardness properties [304]. Extracted with permission.

\section{Current Application on NF Reinforcement Hybrid Composites}

Due to its low manufacturing cost, max strength ratio, and simple manufacturing process, hybrid natural fiber composites have already been widely extensively utilized in numerous textile and engineering applications. Furthermore, natural fiber composites demonstrated a good combination of mechanical qualities for aerospace and automotive applications, including its enhanced impact strength, tensile, bending and compressive behavior, as well as improved fatigue properties. Bio-based hybrid composites are a rapidly increasing product in the industrial sectors as a means of reducing environmental effects in today's society.

\subsection{Automotive}

The automotive industry demands composite materials in order to comply with new regulations and to remain competitive. At present, plant fibers are used in the exterior and interior components in semi- or non-structural applications, fulfilling the performance standards, e.g., elongation, ultimate breaking force, impact strength, flexural properties, flammability, fogging characteristics, acoustic absorption, odor, dimensional stability, aptness for processing dwell time and temperature, crash resistance, and water absorption. A few renowned automakers, e.g., Volkswagen-Audi, Daimler-Chrysler, and Opel-GM, have already begun incorporating natural fiber composites into their passenger car parts, including rear parcel shelf, door trim panels, and seat squabs [305,306]. Table 4 shows the present use of natural fiber in the automobile sector by the big automobile companies.

The prospects for a lightweight design from plant fiber composites are demonstrated, for instance, in Mercedes E-Class's panels and even external underbody panels and Volkswagen's door structures (phenol-formaldehyde/flax composite) [307]. Given the unique qualities of natural fiber composites, an approximately $15 \%$ weight reduction in components is feasible compared to glass fiber reinforced composites. 
Table 4. Lists of natural fibers reinforced hybrid composites currently being used in the automotive industry. Extracted from Ref. [308] with permission.

\begin{tabular}{|c|c|c|}
\hline Automobile Model & Natural Fiber Utilized & Applications \\
\hline Audi A2 & Flax, sisal fibers and polyurethane & Door trim panels \\
\hline BMW 7 Series & Sisal fiber & Door trim panels \\
\hline Chevrolet Impala & Flax fiber and polypropylene & Rear shelf compartment \\
\hline Ford Focus and Fiesta & Kenaf fiber and sun & Interior door panels \\
\hline Honda Pilot & Wood fiber & Floor area parts \\
\hline Mercedes Benz A, C, E and S-class & Flax, hemp, sisal, cotton, abaca and jute fibers & $\begin{array}{l}\text { Underbody panels, seat back rests, engine and } \\
\text { transmission cover and rear panel shelves }\end{array}$ \\
\hline Toyota Prius and Raum & Corn biopolymer, starch and kenaf fiber & $\begin{array}{l}\text { Instrument panels, sun visors, ceiling surface } \\
\text { skins and spare tire cover }\end{array}$ \\
\hline
\end{tabular}

\subsection{Aerospace}

During the early stages of the aircraft industry's development, aircraft structures were invented using wire, wood (natural composite), and fabric compositions. Aluminum alloys have been the dominating material in the aerospace industry since the 1930s. The newest components of civil aircraft are made of natural fibers that are also used as a substructure in conjunction with fibers containing composites and other synthetic fibers, e.g., glass, carbon, and Kevlar. The design of V22 Osprey tiltrotor's wings is extremely rigid and risky, and is most likely to be constructed using fiber composites with low-density materials. In defense aircraft, a fascinating advancement called "stealth" has emerged, which requires the designer to achieve the smallest possible radar cross-section (RCS) by reducing the potentials of early detection via defending radar sets. Constant radius changes are required to create the airframe's essential compound curvatures, which are much easier to build using composites compared to metal and radar-absorbent material (RAM).

\subsection{Oil and Gas}

Hybrid natural fiber-reinforced composites of natural fiber-reinforced composites have been found to have less critical environmental impacts than glass fiber reinforced composites in some applications [309]. Natural fibers have been used with glass fiber for underground pipes; this application is faster and offers adequate strength. However, certain issues, e.g., water absorption and strength, have yet to be studied [310].

\subsection{Maritime}

According to Moreau et al. [311], fiber-reinforced plastic (FRP) structures in boat construction uses primarily thermosetting resins (e.g., vinyl ester, epoxy, polyester, etc.) Only lately have thermoplastic resins (polypropylene, polyamide, PBT, PET, etc.) started being applied in fittings or boat-building. In recent times, the resin structure has evolved in 2 forms: both low styrene content and emission are commercially available despite the evolution of bio-based resins; however, conventional resins are still relevant in the nautical area [174].

The environmental benefits of adhesives and bio-based resins are found in their elimination of toxins in common, their emphasis on human health and the environment, their reduction of hazardous as well as toxic materials and waste, recycling capabilities, and the decline of polluting air emissions. Natural fibers are also gaining popularity in the composites sector. However, their application in structural components is limited due to their generally poor physical characteristics, whereas at present, they are applied in filling functions. Glass fibers provide for $89 \%$ of the fiber's capacity used in composites on a global scale. In contrast, natural fibers account for just 10\%. Simultaneously, several R\&D studies of natural fiber uses are underway, resulting in more industrial uses in the foreseeable future.

Glass fibers were accessible during World War II, shortly after polyester resins were created, as a result of the accidental discovery of a manufacturing method involving blown air on a molten glass stream. Soon after, glass-reinforced plastic became popular, and 
in the early 1950s, GRP boats became accessible. Fiberglass boats are significantly more appealing due to their strength, including their high vibration damping ability, lightweight, low construction costs, high impact resistance, ease of fabrication, maintenance, and repair.

Fiberglass boat construction has evolved over the years to include a variety of means with the sole objective of an improvement in boat construction skills and techniques to fulfill the aims of fiberglass boat building, e.g., to produce lightweight products, corrosion and impact resistance, vibration damping, low cost, and ease of construction. Now, hybrid natural fiber (NF) composites are broadly utilized in a variety of technical applications that comprise marine applications, particularly in boat construction.

\subsection{Textiles}

Pineapple leaves (PAL) have been utilized as threads and fabrics in a variety of nations for centuries. Excellent pina fibers are derived from pineapple leaves in the Philippines and are used to create textiles for table linens, dresses, mats, bags, and other apparel items. Applications of PAL in the textile industry are established in Indonesia, while in Malaysia, the efforts in PAL employment in Malaysia are still in their infancy. The PAL dresses, however, are recognized to be expensive, which is understandable because of the tedious procedures involved.

\section{Estimated Costing for NF as Reinforcement in Hybrid Composites}

Excellent specific properties and cheap natural fiber composites are the primary factors of their attractiveness for wide applications, as reported by Sanjay et al. [303] and Ho et al. [292] The price lists of NF, synthetic fibers, and matrices in the US and Malaysia currencies, USD and MYR, respectively, are tabulated in Table 5. Table 6 tabulated the estimated cost for hybrid NF/synthetic fibers and matrices for numerous applications.

Table 5. Estimated cost of natural, synthetic fiber and matrices in US Dollar (USD) and Malaysia Ringgit (MYR). Extracted from Ref. [292] with permission.

\begin{tabular}{|c|c|c|c|}
\hline \multirow{2}{*}{ No. } & \multirow{2}{*}{ Types of Natural Fiber } & \multicolumn{2}{|c|}{ Cost (Money per Tons) } \\
\hline & & USD & MYR \\
\hline 1. & Bamboo & 500 & 2092.80 \\
\hline 2. & Banana & 890 & 3725.18 \\
\hline 3. & Flax & 3150 & $13,184.64$ \\
\hline 4. & Hemp & 1550 & 6487.68 \\
\hline 5. & Jute & 950 & 3976.32 \\
\hline 6. & Kenaf & 400 & 1674.24 \\
\hline 7. & Pineapple & 455 & 1904.45 \\
\hline 8. & Sisal & 650 & 2720.64 \\
\hline 9. & Sugar palm & 4000 & $16,742.40$ \\
\hline \multirow{2}{*}{ No. } & \multirow{2}{*}{ Types of Synthetic Fiber } & \multicolumn{2}{|c|}{ Cost (Money per Tons) } \\
\hline & & USD & MYR \\
\hline 1. & Carbon & 12,500 & $52,320.00$ \\
\hline 2. & Kevlar (aramid) & 20,000 & $83,712.00$ \\
\hline 3. & Fiber Glass & 980 & 4101.89 \\
\hline 4. & Glass & 1500 & 6278.40 \\
\hline \multirow{2}{*}{ No. } & \multirow{2}{*}{ Types of Matrices } & \multicolumn{2}{|c|}{ Cost (Money per Tons) } \\
\hline & & USD & MYR \\
\hline 1. & Epoxy & 2650 & $11,091.84$ \\
\hline 2. & Polyester & 550 & 2302.08 \\
\hline 3. & Vinyl ester & 1550 & 6487.68 \\
\hline 4. & Polyurethane & 2750 & $11,510.40$ \\
\hline
\end{tabular}

Currency United States Dollar (USD) to Malaysian Ringgit (MYR) on date 8 June 2021. 
Table 6. Estimated costing for NF as reinforcement in hybrid composites (in US Dollar/USD and Malaysia Ringgit/MYR) [303].

\begin{tabular}{|c|c|c|c|c|c|}
\hline \multirow{2}{*}{ No. } & \multicolumn{3}{|c|}{ Reinforced Composite } & \multicolumn{2}{|c|}{$\begin{array}{c}\text { Estimated Cost } \\
\text { (Money per Tons) }\end{array}$} \\
\hline & $\begin{array}{l}\text { Natural } \\
\text { Fiber }\end{array}$ & $\begin{array}{l}\text { Synthetic } \\
\text { Fiber }\end{array}$ & Matrices & USD & MYR \\
\hline 1. & Bamboo & Carbon & Epoxy & 15,650 & $65,504.64$ \\
\hline 2. & Bamboo & Carbon & Polyester & 15,700 & $65,713.92$ \\
\hline 3. & Bamboo & Carbon & Vinyl ester & 16,700 & $69,899.52$ \\
\hline 4. & Bamboo & Carbon & Polyurethane & 17,900 & $74,922.24$ \\
\hline 5. & Bamboo & Kevlar & Epoxy & 25,300 & $105,895.68$ \\
\hline 6. & Bamboo & Kevlar & Polyester & 21,050 & $88,106.88$ \\
\hline 7. & Bamboo & Kevlar & Vinyl ester & 22,100 & $92,501.76$ \\
\hline 8. & Bamboo & Kevlar & Polyurethane & 23,250 & $97,315.20$ \\
\hline 9. & Bamboo & Fiber Glass & Epoxy & 4130 & $17,286.53$ \\
\hline 10. & Bamboo & Fiber Glass & Polyester & 2030 & 8511.59 \\
\hline 11. & Bamboo & Fiber Glass & Vinyl ester & 3030 & $12,704.49$ \\
\hline 12. & Bamboo & Fiber Glass & Polyurethane & 4230 & $17,735.97$ \\
\hline 13. & Bamboo & Glass & Epoxy & 4650 & $19,496.99$ \\
\hline 14. & Bamboo & Glass & Polyester & 2550 & $10,691.90$ \\
\hline 15. & Bamboo & Glass & Vinyl ester & 3550 & $14,884.80$ \\
\hline 16. & Bamboo & Glass & Polyurethane & 4750 & $19,916.27$ \\
\hline 17. & Banana & Carbon & Epoxy & 16,040 & $67,254.12$ \\
\hline 18. & Banana & Carbon & Polyester & 13,940 & $58,449.03$ \\
\hline 19. & Banana & Carbon & Vinyl ester & 14,940 & $62,641.93$ \\
\hline 20. & Banana & Carbon & Polyurethane & 16,140 & $67,673.41$ \\
\hline 21. & Banana & Kevlar & Epoxy & 23,540 & $98,700.87$ \\
\hline 22. & Banana & Kevlar & Polyester & 21,440 & $89,895.78$ \\
\hline 23. & Banana & Kevlar & Vinyl ester & 22,440 & $94,088.68$ \\
\hline 24. & Banana & Kevlar & Polyurethane & 23,640 & $99,120.16$ \\
\hline 25. & Banana & Fiber Glass & Epoxy & 4520 & $18,951.91$ \\
\hline 26. & Banana & Fiber Glass & Polyester & 2420 & $10,146.82$ \\
\hline 27. & Banana & Fiber Glass & Vinyl ester & 3420 & $14,339.72$ \\
\hline 28. & Banana & Fiber Glass & Polyurethane & 4620 & $19,371.20$ \\
\hline 29. & Banana & Glass & Epoxy & 5040 & $21,132.22$ \\
\hline 30. & Banana & Glass & Polyester & 2940 & $12,327.13$ \\
\hline 31. & Banana & Glass & Vinyl ester & 3940 & $16,520.03$ \\
\hline 32. & Banana & Glass & Polyurethane & 5140 & $21,551.51$ \\
\hline 33. & Flax & Carbon & Epoxy & 18,300 & $76,730.07$ \\
\hline 34. & Flax & Carbon & Polyester & 16,200 & $67,924.98$ \\
\hline 35. & Flax & Carbon & Vinyl ester & 17,200 & $72,117.88$ \\
\hline 36. & Flax & Carbon & Polyurethane & 18,400 & $77,149.36$ \\
\hline 37. & Flax & Kevlar & Epoxy & 25,800 & $108,176.82$ \\
\hline 38. & Flax & Kevlar & Polyester & 23,700 & $99,371.73$ \\
\hline 39. & Flax & Kevlar & Vinyl ester & 24,700 & $103,564.63$ \\
\hline 40. & Flax & Kevlar & Polyurethane & 25,900 & $108,596.11$ \\
\hline 41. & Flax & Fiber Glass & Epoxy & 6780 & $28,427.86$ \\
\hline 42. & Flax & Fiber Glass & Polyester & 4680 & $19,622.77$ \\
\hline 43. & Flax & Fiber Glass & Vinyl ester & 5680 & $23,815.67$ \\
\hline 44. & Flax & Fiber Glass & Polyurethane & 6880 & $28,847.15$ \\
\hline 45. & Flax & Glass & Epoxy & 7300 & $30,608.17$ \\
\hline 46. & Flax & Glass & Polyester & 5200 & $21,803.08$ \\
\hline 47. & Flax & Glass & Vinyl ester & 6200 & $25,995.98$ \\
\hline 48. & Flax & Glass & Polyurethane & 7400 & $31,027.46$ \\
\hline 49. & Hemp & Carbon & Epoxy & 16,700 & $70,021.43$ \\
\hline 50. & Hemp & Carbon & Polyester & 14,600 & $61,216.34$ \\
\hline 51. & Hemp & Carbon & Vinyl ester & 15,600 & $65,409.24$ \\
\hline 52. & Hemp & Carbon & Polyurethane & 16,800 & $70,440.72$ \\
\hline 53. & Hemp & Kevlar & Epoxy & 24,200 & $101,468.18$ \\
\hline
\end{tabular}


Table 6. Cont.

\begin{tabular}{|c|c|c|c|c|c|}
\hline \multirow{2}{*}{ No. } & \multicolumn{3}{|c|}{ Reinforced Composite } & \multicolumn{2}{|c|}{$\begin{array}{l}\text { Estimated Cost } \\
\text { (Money per Tons) }\end{array}$} \\
\hline & $\begin{array}{l}\text { Natural } \\
\text { Fiber }\end{array}$ & $\begin{array}{l}\text { Synthetic } \\
\text { Fiber }\end{array}$ & Matrices & USD & MYR \\
\hline 54. & Hemp & Kevlar & Polyester & 24,750 & $107,967.18$ \\
\hline 55. & Hemp & Kevlar & Vinyl ester & 26,300 & $110,273.27$ \\
\hline 56. & Hemp & Kevlar & Polyurethane & 29,050 & $121,803.74$ \\
\hline 57. & Hemp & Fiber Glass & Epoxy & 5180 & $21,719.22$ \\
\hline 58. & Hemp & Fiber Glass & Polyester & 3080 & $12,914.13$ \\
\hline 59. & Hemp & Fiber Glass & Vinyl ester & 4080 & $17,107.03$ \\
\hline 60. & Hemp & Fiber Glass & Polyurethane & 5280 & $22,138.51$ \\
\hline 61. & Hemp & Glass & Epoxy & 5700 & $23,899.53$ \\
\hline 62. & Hemp & Glass & Polyester & 3600 & $15,094.44$ \\
\hline 63. & Hemp & Glass & Vinyl ester & 4600 & $19,287.34$ \\
\hline 64. & Hemp & Glass & Polyurethane & 5800 & $24,318.82$ \\
\hline 65. & Jute & Carbon & Epoxy & 16,100 & $67,505.69$ \\
\hline 66. & Jute & Carbon & Polyester & 14,000 & $58,700.60$ \\
\hline 67. & Jute & Carbon & Vinyl ester & 15,000 & $62,893.50$ \\
\hline 68. & Jute & Carbon & Polyurethane & 16,200 & $67,924.98$ \\
\hline 69. & Jute & Kevlar & Epoxy & 23,600 & $98,952.44$ \\
\hline 70. & Jute & Kevlar & Polyester & 21,500 & $90,147.35$ \\
\hline 71. & Jute & Kevlar & Vinyl ester & 22,500 & $94,340.25$ \\
\hline 72. & Jute & Kevlar & Polyurethane & 23,700 & $99,371.73$ \\
\hline 73. & Jute & Fiber Glass & Epoxy & 4580 & $19,203.48$ \\
\hline 74. & Jute & Fiber Glass & Polyester & 2480 & $10,398.39$ \\
\hline 75. & Jute & Fiber Glass & Vinyl ester & 3480 & $14,591.29$ \\
\hline 76. & Jute & Fiber Glass & Polyurethane & 4680 & $19,622.77$ \\
\hline 77. & Jute & Glass & Epoxy & 5100 & $21,383.79$ \\
\hline 78. & Jute & Glass & Polyester & 3000 & $12,578.70$ \\
\hline 79. & Jute & Glass & Vinyl ester & 4000 & $16,771.60$ \\
\hline 80. & Jute & Glass & Polyurethane & 5200 & $21,803.08$ \\
\hline 81. & Kenaf & Carbon & Epoxy & 15,550 & $65,199.60$ \\
\hline 82. & Kenaf & Carbon & Polyester & 13,450 & $56,394.50$ \\
\hline 83. & Kenaf & Carbon & Vinyl ester & 14,450 & $60,587.40$ \\
\hline 84. & Kenaf & Carbon & Polyurethane & 15,650 & $65,618.88$ \\
\hline 85. & Kenaf & Kevlar & Epoxy & 23,050 & $96,646.35$ \\
\hline 86. & Kenaf & Kevlar & Polyester & 20,950 & $87,841.25$ \\
\hline 87. & Kenaf & Kevlar & Vinyl ester & 21,950 & $92,034.15$ \\
\hline 88. & Kenaf & Kevlar & Polyurethane & 23,150 & $97,065.63$ \\
\hline 89. & Kenaf & Fiber Glass & Epoxy & 4030 & $16,897.39$ \\
\hline 90. & Kenaf & Fiber Glass & Polyester & 1930 & 8092.30 \\
\hline 91. & Kenaf & Fiber Glass & Vinyl ester & 2930 & $12,285.20$ \\
\hline 92. & Kenaf & Fiber Glass & Polyurethane & 4130 & $17,316.68$ \\
\hline 93. & Kenaf & Glass & Epoxy & 4550 & $19,077.69$ \\
\hline 94. & Kenaf & Glass & Polyester & 2450 & $10,272.60$ \\
\hline 95. & Kenaf & Glass & Vinyl ester & 3450 & $14,465.50$ \\
\hline 96. & Kenaf & Glass & Polyurethane & 4650 & $19,496.99$ \\
\hline 97. & Pineapple & Carbon & Epoxy & 15,605 & $65,430.20$ \\
\hline 98. & Pineapple & Carbon & Polyester & 13,505 & $56,625.11$ \\
\hline 99. & Pineapple & Carbon & Vinyl ester & 14,505 & $60,818.01$ \\
\hline 100. & Pineapple & Carbon & Polyurethane & 15,705 & $65,849.49$ \\
\hline 101. & Pineapple & Kevlar & Epoxy & 23,105 & $96,876.95$ \\
\hline 102. & Pineapple & Kevlar & Polyester & 21,005 & $88,071.86$ \\
\hline 103. & Pineapple & Kevlar & Vinyl ester & 22,005 & $92,264.76$ \\
\hline 104. & Pineapple & Kevlar & Polyurethane & 23,205 & $97,296.24$ \\
\hline 105. & Pineapple & Fiber Glass & Epoxy & 4085 & $17,128.00$ \\
\hline 106. & Pineapple & Fiber Glass & Polyester & 1985 & 8322.91 \\
\hline 107. & Pineapple & Fiber Glass & Vinyl ester & 2985 & $12,515.81$ \\
\hline 108. & Pineapple & Fiber Glass & Polyurethane & 4185 & $17,547.29$ \\
\hline
\end{tabular}


Table 6. Cont.

\begin{tabular}{|c|c|c|c|c|c|}
\hline \multirow{2}{*}{ No. } & \multicolumn{3}{|c|}{ Reinforced Composite } & \multicolumn{2}{|c|}{$\begin{array}{c}\text { Estimated Cost } \\
\text { (Money per Tons) }\end{array}$} \\
\hline & $\begin{array}{l}\text { Natural } \\
\text { Fiber }\end{array}$ & $\begin{array}{l}\text { Synthetic } \\
\text { Fiber }\end{array}$ & Matrices & USD & MYR \\
\hline 109. & Pineapple & Glass & Epoxy & 4605 & $19,308.30$ \\
\hline 110. & Pineapple & Glass & Polyester & 2505 & $10,503.21$ \\
\hline 111. & Pineapple & Glass & Vinyl ester & 3505 & $14,696.11$ \\
\hline 112. & Pineapple & Glass & Polyurethane & 4705 & $19,727.59$ \\
\hline 113. & Sisal & Carbon & Epoxy & 15,800 & $66,247.82$ \\
\hline 114. & Sisal & Carbon & Polyester & 13,700 & $57,442.73$ \\
\hline 115. & Sisal & Carbon & Vinyl ester & 14,700 & $61,635.63$ \\
\hline 116. & Sisal & Carbon & Polyurethane & 15,900 & $66,667.11$ \\
\hline 117. & Sisal & Kevlar & Epoxy & 23,300 & $97,694.57$ \\
\hline 118. & Sisal & Kevlar & Polyester & 21,200 & $88,889.48$ \\
\hline 119. & Sisal & Kevlar & Vinyl ester & 22,200 & $93,082.38$ \\
\hline 120. & Sisal & Kevlar & Polyurethane & 23,400 & $98,113.86$ \\
\hline 121. & Sisal & Fiber Glass & Epoxy & 4280 & $17,945.61$ \\
\hline 122. & Sisal & Fiber Glass & Polyester & 2180 & 9140.52 \\
\hline 123. & Sisal & Fiber Glass & Vinyl ester & 3180 & $13,333.42$ \\
\hline 124. & Sisal & Fiber Glass & Polyurethane & 4380 & $18,364.90$ \\
\hline 125. & Sisal & Glass & Epoxy & 4800 & $20,125.92$ \\
\hline 126. & Sisal & Glass & Polyester & 2700 & $11,320.83$ \\
\hline 127. & Sisal & Glass & Vinyl ester & 3700 & $15,513.73$ \\
\hline 128. & Sisal & Glass & Polyurethane & 4900 & $20,545.21$ \\
\hline 129. & Sugar palm & Carbon & Epoxy & 19,150 & $80,294.04$ \\
\hline 130. & Sugar palm & Carbon & Polyester & 17,050 & $71,488.94$ \\
\hline 131. & Sugar palm & Carbon & Vinyl ester & 18,050 & $75,681.85$ \\
\hline 132. & Sugar palm & Carbon & Polyurethane & 19,250 & $80,713.32$ \\
\hline 133. & Sugar palm & Kevlar & Epoxy & 26,650 & $111,740.78$ \\
\hline 134. & Sugar palm & Kevlar & Polyester & 24,550 & $102,935.69$ \\
\hline 135. & Sugar palm & Kevlar & Vinyl ester & 25,550 & $107,128.60$ \\
\hline 136. & Sugar palm & Kevlar & Polyurethane & 26,750 & $112,160.07$ \\
\hline 137. & Sugar palm & Fiber Glass & Epoxy & 7630 & $31,991.83$ \\
\hline 138. & Sugar palm & Fiber Glass & Polyester & 5530 & $23,186.74$ \\
\hline 139. & Sugar palm & Fiber Glass & Vinyl ester & 6530 & $27,379.64$ \\
\hline 140. & Sugar palm & Fiber Glass & Polyurethane & 7730 & $32,411.12$ \\
\hline 141. & Sugar palm & Glass & Epoxy & 8150 & $34,172.14$ \\
\hline 142. & Sugar palm & Glass & Polyester & 6050 & $25,367.04$ \\
\hline 143. & Sugar palm & Glass & Vinyl ester & 7050 & $29,559.94$ \\
\hline 144. & Sugar palm & Glass & Polyurethane & 8250 & $34,591.42$ \\
\hline
\end{tabular}

Currency United States Dollar (USD) to Malaysian Ringgit (MYR) on date 8 June 2021.

\section{Conclusions and Future Directions}

Currently, the production of many bio-based plastics has been demonstrated at the demo and pilot scale, and some had been hugely commercialized. Some of the products are partly bio-based (i.e., polyamides, polyols bio-based polyethylene (PE), polypropylene (PP), or polyethylene terephthalate (PET)), and some of them are entirely new plastics (i.e., thermoplastic starch (TPS), polyhydroxybutyrate (PHB), polyhydroxyalkanoates (PHAs), or poly (lactic acid) (PLA). Partly bio-based plastics often require petrochemical monomers that cannot be resembled by bio-based substitutions, at least not at a reasonable price. Today's bio-based plastics are sophisticated materials that could technically be a substitute for around $90 \%$ of the plastics we use today.

Natural fiber reinforced hybrid composites are superior to petroleum-based composites because they have a higher strength-to-weight ratio, a low manufacturing cost due to their facile processes, and are environmentally beneficial. As a result, natural fiber composites have numerous advantages in commercial, industrial and engineering applications. Natural fibers, on the other hand, have lower strength than synthetic composites, but 
when combined with synthetic or biosynthetic composites, they offer high strength with a lower environmental impact. This study outlines the properties of natural fiber, composite hybridization, estimated costing, and natural fiber applications in various industries. This gives a comprehensive idea of how natural fibers are processed and commercialized. The characteristics of natural fibers such as sisal, jute, abaca, sugar palm, kenaf and hemp, were studied. In addition, the numerous applications of the hybrid composites in various sectors were described.

Author Contributions: Writing—original draft preparation, M.J.S., R.A.I., M.M.H.; conceptualization, M.J.S., R.A.I.; methodology, M.J.S., R.A.I.; writing-review and editing, M.J.S., R.A.I., M.M.H., A.K., M.T.H.S., S.M.S., C.M.R., F.N.W., F.Z., M.A.A., F.S.M.R., S.S.; supervision, M.J.S., R.A.I.; project administration, M.J.S., R.A.I.; Funding-M.Y.M.Z. All authors have read and agreed to the published version of the manuscript.

Funding: This study was funded by Fundamental Research Grant Scheme (FRGS) Vot 59624/Correlation of Manufacturing Defects, Interfacial Adhesion, Physical and Mechanical Properties of Plant Fiber Reinforced Hybrid Composite Material Towards Compatibility Behaviors. Besides this, the authors would like express gratitude for the financial support received from Universiti Teknologi Malaysia, project CRG 30.3: Retardant coating using graphene/bamboo aerogel mixtures on SAR robotics system, grant number PY/2020/03495-R.J130000.7351.4B534. The research has been carried out under program Research Excellence Consortium (JPT (BPKI) 1000/016/018/25 (57)) provided by Ministry of Higher Education Malaysia (MOHE). The authors also would like to thank Universiti Teknologi Malaysia (UTM) for work and facilities support. The article processing fee of this manuscript is funded by Research Management Centre, Universiti Putra Malaysia.

Institutional Review Board Statement: Not applicable.

Informed Consent Statement: Not applicable.

Acknowledgments: The authors would like to thank all the technicians and support staffs from Maritime Technology Lab, Universiti Malaysia Terengganu and Biocomposite Lab, INTROP, Universiti Putra Malaysia for their great contribution and help. This study was funded by Fundamental Research Grant Scheme (FRGS) Vot 59624/Correlation of Manufacturing Defects, Interfacial Adhesion, Physical and Mechanical Properties of Plant Fiber Reinforced Hybrid Composite Material Towards Compatibility Behaviors. Besides this, the authors would like express gratitude for the financial support received from Universiti Teknologi Malaysia, project CRG 30.3: Retardant coating using graphene/bamboo aerogel mixtures on SAR robotics system, grant number PY/2020/03495R.J130000.7351.4B534. The research has been carried out under program Research Excellence Consortium (JPT (BPKI) 1000/016/018/25 (57)) provided by Ministry of Higher Education Malaysia (MOHE). The author also would like to thank Universiti Teknologi Malaysia (UTM) for work and facilities support.

Conflicts of Interest: The authors declare no conflict of interest.

\section{References}

1. Haris, N.I.N.; Ilyas, R.A.; Hassan, M.Z.; Sapuan, S.M.; Afdzaluddin, A.; Jamaludin, K.R.; Zaki, S.A.; Ramlie, F. Dynamic Mechanical Properties and Thermal Properties of Longitudinal Basalt/Woven Glass Fiber Reinforced Unsaturated Polyester Hybrid Composites. Polymers 2021, 13, 3343. [CrossRef]

2. Sapuan, S.M.; Aulia, H.S.; Ilyas, R.A.; Atiqah, A.; Dele-Afolabi, T.T.; Nurazzi, M.N.; Supian, A.B.M.; Atikah, M.S.N. Mechanical properties of longitudinal basalt/woven-glass-fiber-reinforced unsaturated polyester-resin hybrid composites. Polymers 2020, 12, 2211. [CrossRef] [PubMed]

3. Sanjay, M.R.; Arpitha, G.R.; Naik, L.L.; Gopalakrishna, K.; Yogesha, B. Applications of Natural Fibers and Its Composites: An Overview. Nat. Resour. 2016, 7, 108-114. [CrossRef]

4. Sanjay, M.R.; Arpitha, G.R.; Senthamaraikannan, P.; Kathiresan, M.; Saibalaji, M.A.; Yogesha, B. The Hybrid Effect of Jute/Kenaf/EGlass Woven Fabric Epoxy Composites for Medium Load Applications: Impact, Inter-Laminar Strength, and Failure Surface Characterization. J. Nat. Fibers 2019, 16, 600-612. [CrossRef]

5. Madhu, P.; Sanjay, M.R.; Senthamaraikannan, P.; Pradeep, S.; Saravanakumar, S.S.; Yogesha, B. A review on synthesis and characterization of commercially available natural fibers: Part II. J. Nat. Fibers 2019, 16, 25-36. [CrossRef]

6. Ghelli, D.; Minak, G. Low velocity impact and compression after impact tests on thin carbon/epoxy laminates. Compos. Part. B Eng. 2011, 42, 2067-2079. [CrossRef] 
7. Boria, S.; Pavlovic, A.; Fragassa, C.; Santulli, C. Modeling of falling weight impact behavior of hybrid basalt/flax vinylester composites. Procedia Eng. 2016, 167, 223-230. [CrossRef]

8. Harussani, M.M.; Sapuan, S.M.; Rashid, U.; Khalina, A. Development and Characterization of Polypropylene Waste from Personal Protective Equipment (PPE)-Derived Char-Filled Sugar Palm Starch Biocomposite Briquettes. Polymers 2021, 13, 1707. [CrossRef]

9. Chan, J.X.; Wong, J.F.; Petrů, M.; Hassan, A.; Nirmal, U.; Othman, N.; Ilyas, R.A. Effect of Nanofillers on Tribological Properties of Polymer Nanocomposites: A Review on Recent Development. Polymers 2021, 13, 2867. [CrossRef]

10. Nurazzi, N.M.; Sabaruddin, F.A.; Harussani, M.M.; Kamarudin, S.H.; Rayung, M.; Asyraf, M.R.M.; Aisyah, H.A.; Norrrahim, M.N.F.; Ilyas, R.A.; Abdullah, N.; et al. Mechanical Performance and Applications of CNTs Reinforced Polymer Composites-A Review. Nanomaterials 2021, 11, 2186. [CrossRef]

11. Poodts, E.; Minak, G.; Mazzocchetti, L.; Giorgini, L. Fabrication, process simulation and testing of a thick CFRP component using the RTM process. Compos. Part. B Eng. 2014, 56, 673-680. [CrossRef]

12. Malkapuram, R.; Kumar, V.; Singh Negi, Y. Recent development in natural fiber reinforced polypropylene composites. J. Reinf. Plast. Compos. 2009, 28, 1169-1189. [CrossRef]

13. Harussani, M.M.; Sapuan, S.M.; Rashid, U.; Khalina, A.; Ilyas, R.A. Pyrolysis of polypropylene plastic waste into carbonaceous char: Priority of plastic waste management amidst COVID-19 pandemic. Sci. Total Environ. 2021, 149911. [CrossRef]

14. De Paola, S.; Fragassa, C.; Minak, G.; Pavlovic, A. Green Composites: A review of state of art. Carbon N.Y. 2013, 1, $230-240$.

15. Hyseni, A.; De Paola, S.; Minak, G.; Fragassa, C. Mechanical characterization of ecocomposites. In Proceedings of the 30th Danubia Adria Symposium on Advanced Mechanics, Damir Semenski, Zagreb, Croatia, 25 September 2013; pp. 25-28.

16. Alotaibi, M.D.; Alshammari, B.A.; Saba, N.; Alothman, O.Y.; Sanjay, M.R.; Almutairi, Z.; Jawaid, M. Characterization of natural fiber obtained from different parts of date palm tree (Phoenix dactylifera L.). Int. J. Biol. Macromol. 2019, 135, 69-76. [CrossRef]

17. Vinod, A.; Vijay, R.; Singaravelu, D.L.; Sanjay, M.R.; Siengchin, S.; Yagnaraj, Y.; Khan, S. Extraction and characterization of natural fiber from stem of cardiospermum halicababum. J. Nat. Fibers 2021, 18, 898-908. [CrossRef]

18. Kadier, A.; Ilyas, R.A.; Huzaifah, M.R.M.; Harihastuti, N.; Sapuan, S.M.; Harussani, M.M.; Azlin, M.N.M.; Yuliasni, R.; Ibrahim, R.; Atikah, M.S.N.; et al. Use of Industrial Wastes as Sustainable Nutrient Sources for Bacterial Cellulose (BC) Production: Mechanism, Advances, and Future Perspectives. Polymers 2021, 13, 3365. [CrossRef]

19. Faruk, O.; Bledzki, A.K.; Fink, H.-P.; Sain, M. Biocomposites reinforced with natural fibers: 2000. Prog. Polym. Sci. 2012, 37, 1552-1596. [CrossRef]

20. Garkhail, S.K.; Heijenrath, R.W.H.; Peijs, T. Mechanical properties of natural-fibre-mat-reinforced thermoplastics based on flax fibres and polypropylene. Appl. Compos. Mater. 2000, 7, 351-372. [CrossRef]

21. Lee, C.H.; Khalina, A.; Nurazzi, N.M.; Norli, A.; Harussani, M.M.; Rafiqah, S.; Aisyah, H.A.; Ramli, N. The Challenges and Future Perspective of Woven Kenaf Reinforcement in Thermoset Polymer Composites in Malaysia: A Review. Polymers 2021, 13, 1390. [CrossRef]

22. Wambua, P.; Ivens, J.; Verpoest, I. Natural fibres: Can they replace glass in fibre reinforced plastics? Compos. Sci. Technol. 2003, 63, 1259-1264. [CrossRef]

23. Rao, K.M.M.; Rao, K.M. Extraction and tensile properties of natural fibers: Vakka, date and bamboo. Compos. Struct. 2007, 77, 288-295. [CrossRef]

24. Jha, K.; Tyagi, Y.K.; Kumar, R.; Sharma, S.; Roslim, M.; Huzaifah, M.; Li, C.; Ilyas, R.A.; Dwivedi, S.P.; Saxena, A.; et al. Assessment of Dimensional Stability, Biodegradability, and Fracture Energy of Bio-Composites Reinforced with Novel Pine Cone. Polymers 2021, 13, 3260. [CrossRef]

25. Kumari, N.; Bangar, S.P.; Petrů, M.; Ilyas, R.A.; Singh, A.; Kumar, P. Development and Characterization of Fenugreek Protein-Based Edible Film. Foods 2021, 10, 1976. [CrossRef]

26. Tarique, J.; Sapuan, S.M.; Khalina, A.; Sherwani, S.F.K.; Yusuf, J.; Ilyas, R.A. Recent developments in sustainable arrowroot (Maranta arundinacea Linn) starch biopolymers, fibres, biopolymer composites and their potential industrial applications: A review. J. Mater. Res. Technol. 2021, 13, 1191-1219. [CrossRef]

27. Misri, S.; Leman, Z.; Sapuan, S.M.; Ishak, M.R. Mechanical properties and fabrication of small boat using woven glass/sugar palm fibres reinforced unsaturated polyester hybrid composite. IOP Conf. Ser. Mater. Sci. Eng. 2010, 11, 012015. [CrossRef]

28. Kamaruddin, Z.H.; Jumaidin, R.; Selamat, M.Z.; Ilyas, R.A. Characteristics and Properties of Lemongrass (Cymbopogan Citratus): A Comprehensive Review. J. Nat. Fibers 2021, 18, 1-18. [CrossRef]

29. Dashtizadeh, Z.; Abdan, K.; Jawaid, M.; Khan, M.A.; Behmanesh, M.; Dashtizadeh, M.; Cardona, F.; Ishak, M. Mechanical and thermal properties of natural fibre based hybrid composites: A review. Pertanika J. Sci. Technol. 2017, 25, 1103-1122.

30. Nurazzi, N.M.; Asyraf, M.R.M.; Rayung, M.; Norrrahim, M.N.F.; Shazleen, S.S.; Rani, M.S.A.; Shafi, A.R.; Aisyah, H.A.; Radzi, M.H.M.; Sabaruddin, F.A.; et al. Thermogravimetric Analysis Properties of Cellulosic Natural Fiber Polymer Composites: A Review on Influence of Chemical Treatments. Polymers 2021, 13, 2710. [CrossRef]

31. Nurazzi, N.M.; Asyraf, M.R.M.; Fatimah Athiyah, S.; Shazleen, S.S.; Rafiqah, S.A.; Harussani, M.M.; Kamarudin, S.H.; Razman, M.R.; Rahmah, M.; Zainudin, E.S.; et al. A Review on Mechanical Performance of Hybrid Natural Fiber Polymer Composites for Structural Applications. Polymers 2021, 13, 2170. [CrossRef]

32. Sapuan, S.M.; Lok, H.Y.; Ishak, M.R.; Misri, S. Mechanical properties of hybrid glass/sugar palm fibre reinforced unsaturated polyester composites. Chin. J. Polym. Sci. 2013, 31, 1394-1403. [CrossRef] 
33. Afzaluddin, A.; Jawaid, M.; Salit, M.S.; Ishak, M.R. Physical and mechanical properties of sugar palm/glass fiber reinforced thermoplastic polyurethane hybrid composites. J. Mater. Res. Technol. 2019, 8, 950-959. [CrossRef]

34. Baihaqi, N.M.Z.N.; Khalina, A.; Nurazzi, N.M.; Aisyah, H.A.; Sapuan, S.M.; Ilyas, R.A. Effect of fiber content and their hybridization on bending and torsional strength of hybrid epoxy composites reinforced with carbon and sugar palm fibers. Polimery 2021, 66, 36-43. [CrossRef]

35. Safri, S.N.A.; Sultan, M.T.H.; Shah, A.U.M. Characterization of benzoyl treated sugar palm/glass fibre hybrid composites. J. Mater. Res. Technol. 2020, 9, 11563-11573. [CrossRef]

36. Safri, S.N.A.; Sultan, M.T.H.; Jawaid, M.; Abdul Majid, M.S. Analysis of dynamic mechanical, low-velocity impact and compression after impact behaviour of benzoyl treated sugar palm/glass/epoxy composites. Compos. Struct. 2019, $226,111308$. [CrossRef]

37. Jumaidin, R.; Sapuan, S.M.; Jawaid, M.; Ishak, M.R.; Sahari, J. Thermal, mechanical, and physical properties of seaweed/sugar palm fibre reinforced thermoplastic sugar palm Starch/Agar hybrid composites. Int. J. Biol. Macromol. 2017, 97, 606-615. [CrossRef]

38. Radzi, A.M.; Sapuan, S.M.; Jawaid, M.; Mansor, M.R. Water absorption, thickness swelling and thermal properties of roselle/sugar palm fibre reinforced thermoplastic polyurethane hybrid composites. J. Mater. Res. Technol. 2019. [CrossRef]

39. Ibrahim, M.I.J.; Sapuan, S.M.; Zainudin, E.S.; Zuhri, M.Y.M. Preparation and characterization of cornhusk/sugar palm fiber reinforced Cornstarch-based hybrid composites. J. Mater. Res. Technol. 2020, 9, 200-211. [CrossRef]

40. Mohd Nurazzi, N.; Khalina, A.; Sapuan, S.M.; Rahmah, M. Development of sugar palm yarn/glass fibre reinforced unsaturated polyester hybrid composites. Mater. Res. Express 2018, 5, 045308. [CrossRef]

41. Edhirej, A.; Sapuan, S.M.; Jawaid, M.; Zahari, N.I. Cassava/sugar palm fiber reinforced cassava starch hybrid composites: Physical, thermal and structural properties. Int. J. Biol. Macromol. 2017, 101, 75-83. [CrossRef]

42. Bachtiar, D.; Siregar, J.P.; bin Sulaiman, A.S.; bin Mat Rejab, M.R. Tensile Properties of Hybrid Sugar Palm/Kenaf Fibre Reinforced Polypropylene Composites. Appl. Mech. Mater. 2014, 695, 155-158.

43. Ibrahim, M.I.J.; Sapuan, S.M.; Zainudin, E.S.; Zuhri, M.Y.M.; Edhirej, A. Processing and Characterization of Cornstalk/Sugar Palm Fiber Reinforced Cornstarch Biopolymer Hybrid Composites. In Advanced Processing, Properties, and Applications of Starch and Other Bio-Based Polymers; Elsevier: Amsterdam, The Netherlands, 2020; pp. 35-46.

44. Siregar, J.P.; Zalinawati, M.; Cionita, T.; Rejab, M.R.M.; Mawarnie, I.; Jaafar, J.; Hamdan, M.H.M. Mechanical properties of hybrid sugar palm/ramie fibre reinforced epoxy composites. Mater. Today Proc. 2021, 46, 1729-1734. [CrossRef]

45. Razali, N.; Sapuan, S.M.; Razali, N. Mechanical Properties and Morphological Analysis of Roselle/Sugar Palm Fiber Reinforced Vinyl Ester Hybrid Composites. In Natural Fibre Reinforced Vinyl Ester and Vinyl Polymer Composites; Elsevier: Amsterdam, The Netherlands, 2018; pp. 169-180.

46. Mukhtar, I.; Leman, Z.; Zainudin, E.S.; Ishak, M.R. Hybrid and Nonhybrid Laminate Composites of Sugar Palm and Glass Fibre-Reinforced Polypropylene: Effect of Alkali and Sodium Bicarbonate Treatments. Int. J. Polym. Sci. 2019, 2019, 12. [CrossRef]

47. Davoodi, M.M.; Sapuan, S.M.; Ahmad, D.; Ali, A.; Khalina, A.; Jonoobi, M. Mechanical properties of hybrid kenaf/glass reinforced epoxy composite for passenger car bumper beam. Mater. Des. 2010, 31, 4927-4932. [CrossRef]

48. Atiqah, A.; Maleque, M.A.; Jawaid, M.; Iqbal, M. Development of kenaf-glass reinforced unsaturated polyester hybrid composite for structural applications. Compos. Part. B Eng. 2014, 56. [CrossRef]

49. Jaafar, C.N.A.; Zainol, I.; Rizal, M.A.M. Preparation and characterisation of epoxy/silica/kenaf composite using hand lay-up method. In Proceedings of the 27th Scientific Conference of the Microscopy Society Malaysia (27th SCMSM 2018), Melaka, Malaysia, 3 December 2018; pp. 2-6.

50. Aiza Jaafar, C.N.; Zainol, I.; Ishak, N.S.; Ilyas, R.A.; Sapuan, S.M. Effects of the Liquid Natural Rubber (LNR) on Mechanical Properties and Microstructure of Epoxy/Silica/Kenaf Hybrid Composite for Potential Automotive Applications. J. Mater. Res. Technol. 2021, 12, 1026-1038. [CrossRef]

51. Chee, S.S.; Jawaid, M.; Alothman, O.Y.; Fouad, H. Effects of Nanoclay on Mechanical and Dynamic Mechanical Properties of Bamboo/Kenaf Reinforced Epoxy Hybrid Composites. Polymers 2021, 13, 395. [CrossRef]

52. Hammami, H.; Jawaid, M.; Kallel, A. Effects of oil palm and montmorillonite nanofillers on stiffness and interfacial adhesion of kenaf/epoxy hybrid nanocomposites. Polym. Compos. 2021, 42, 2948-2957. [CrossRef]

53. Mirzaei, J.; Fereidoon, A.; Ghasemi-Ghalebahman, A. Experimental study on mechanical properties of polypropylene nanocomposites reinforced with a hybrid graphene/PP-g-MA/kenaf fiber by response surface methodology. J. Elastomers Plast. 2021, 11, 009524432110153. [CrossRef]

54. Sabaruddin, F.A.; Paridah, M.T.; Sapuan, S.M.; Ilyas, R.A.; Lee, S.H.; Abdan, K.; Mazlan, N.; Roseley, A.S.M.; Abdul Khalil, H.P.S. The effects of unbleached and bleached nanocellulose on the thermal and flammability of polypropylene-reinforced kenaf core hybrid polymer bionanocomposites. Polymers 2020, 13, 116. [CrossRef]

55. Supian, A.B.M.; Sapuan, S.M.; Zuhri, M.Y.M.; Zainudin, E.S.; Ya, H.H.; Hisham, H.N. Effect of winding orientation on energy absorption and failure modes of filament wound kenaf/glass fibre reinforced epoxy hybrid composite tubes under intermediatevelocity impact (IVI) load. J. Mater. Res. Technol. 2021, 10, 1-14. [CrossRef]

56. Suriani, M.J.; Zainudin, H.A.; Ilyas, R.A.; Petrů, M.; Sapuan, S.M.; Ruzaidi, C.M.; Mustapha, R. Kenaf Fiber/Pet Yarn Reinforced Epoxy Hybrid Polymer Composites: Morphological, Tensile, and Flammability Properties. Polymers 2021, 13, 1532. [CrossRef] [PubMed] 
57. Tamrakar, S.; Kiziltas, A.; Mielewski, D.; Zander, R. Characterization of kenaf and glass fiber reinforced hybrid composites for underbody shield applications. Compos. Part. B Eng. 2021, 216, 108805. [CrossRef]

58. Yahaya, R.; Sapuan, S.M.; Jawaid, M.; Leman, Z.; Zainudin, E.S. Mechanical performance of woven kenaf-Kevlar hybrid composites. J. Reinf. Plast. Compos. 2014, 33, 2242-2254. [CrossRef]

59. Alavudeen, A.; Rajini, N.; Karthikeyan, S.; Thiruchitrambalam, M.; Venkateshwaren, N. Mechanical properties of banana/kenaf fiber-reinforced hybrid polyester composites: Effect of woven fabric and random orientation. Mater. Des. 2015, 66, $246-257$. [CrossRef]

60. Nampoothiri, E.N.; Bensam Raj, J.; Thanigaivelan, R.; Karuppasamy, R. Experimental investigation on mechanical and biodegradation properties of indian almond-kenaf fiber-reinforced hybrid composites for construction applications. J. Nat. Fibers 2020, 17, 1-11. [CrossRef]

61. Prabhu, L.; Krishnaraj, V.; Gokulkumar, S.; Sathish, S.; Sanjay, M.R.; Siengchin, S. Mechanical, chemical and sound absorption properties of glass/kenaf/waste tea leaf fiber-reinforced hybrid epoxy composites. J. Ind. Text. 2020, 1528083720957392. [CrossRef]

62. Hanan, F.; Jawaid, M.; Md Tahir, P. Mechanical performance of oil palm/kenaf fiber-reinforced epoxy-based bilayer hybrid composites. J. Nat. Fibers 2020, 17, 155-167. [CrossRef]

63. Dhar Malingam, S.; Ng, L.F.; Chan, K.H.; Subramaniam, K.; Selamat, M.Z.; Zakaria, K.A. The static and dynamic mechanical properties of kenaf/glass fibre reinforced hybrid composites. Mater. Res. Express 2018, 5, 95304. [CrossRef]

64. Sosiati, H.; Shofie, Y.A.; Nugroho, A.W. Tensile properties of Kenaf/E-glass reinforced hybrid polypropylene (PP) composites with different fiber loading. Ph.D. Thesis, Kyushu University, Fukuoka, Japan, 2018.

65. Ismail, A.S.; Jawaid, M.; Naveen, J. Void content, tensile, vibration and acoustic properties of kenaf/bamboo fiber reinforced epoxy hybrid composites. Materials 2019, 12, 2094. [CrossRef]

66. Mirbagheri, J.; Tajvidi, M.; Hermanson, J.C.; Ghasemi, I. Tensile Properties of Wood Flour/Kenaf Fiber Polypropylene Hybrid Composites. J. Appl. Polym. Sci. 2007, 105, 3054-3059. [CrossRef]

67. Haryati, A.; Razali, N.; Petrů, M.; Taha, M.; Muhammad, N.; Ilyas, R.A. Effect of Chemically Treated Kenaf Fibre on Mechanical and Thermal Properties of PLA Composites Prepared through Fused Deposition Modeling (FDM). Polymers 2021, $13,3299$. [CrossRef]

68. Suriani, M.J.; Radzi, F.S.M.; Ilyas, R.A.; Petrů, M.; Sapuan, S.M.; Ruzaidi, C.M. Flammability, Tensile, and Morphological Properties of Oil Palm Empty Fruit Bunches Fiber/Pet Yarn-Reinforced Epoxy Fire Retardant Hybrid Polymer Composites. Polymers 2021, 13, 1282. [CrossRef]

69. Hanan, F.; Jawaid, M.; Paridah, M.T.; Naveen, J. Characterization of Hybrid Oil Palm Empty Fruit Bunch/Woven Kenaf Fabric-Reinforced Epoxy Composites. Polymers 2020, 12, 2052. [CrossRef]

70. Suradi, S.S.; Yunus, R.M.; Beg, M.D.H.; Rivai, M.; Yusof, Z.A.M. Oil palm bio-fiber reinforced thermoplastic composites-effects of matrix modification on mechanical and thermal properties. J. Appl. Sci. 2010, 10, 3271-3276. [CrossRef]

71. Ramlee, N.A.; Jawaid, M.; Zainudin, E.S.; Yamani, S.A.K. Tensile, physical and morphological properties of oil palm empty fruit bunch/sugarcane bagasse fibre reinforced phenolic hybrid composites. J. Mater. Res. Technol. 2019, 8, 3466-3474. [CrossRef]

72. Muhammad Amir, S.M.; Hameed Sultan, M.T.; Md Shah, A.U.; Jawaid, M.; Safri, S.N.A.; Mohd, S.; Mohd Salleh, K.A. Low Velocity Impact and Compression after Impact Properties on Gamma Irradiated Kevlar/Oil Palm Empty Fruit Bunch Hybrid Composites. Coatings 2020, 10, 646. [CrossRef]

73. Islam, M.; Gupta, A.; Rivai, M.; Beg, M. Characterization of microwave-treated oil palm empty fruit bunch/glass fibre/polypropylene composites. J. Thermoplast. Compos. Mater. 2017, 30, 986-1002. [CrossRef]

74. Khalil, H.P.S.A.; Hanida, S.; Kang, C.W.; Fuaad, N.A.N. Agro-hybrid composite: The effects on mechanical and physical properties of oil palm fiber (EFB)/glass hybrid reinforced polyester composites. J. Reinf. Plast. Compos. 2007, 26, 203-218. [CrossRef]

75. Rozman, H.D.; Tay, G.S.; Kumar, R.N.; Abusamah, A.; Ismail, H.; Mohd, I.Z.A. The effect of oil extraction of the oil palm empty fruit bunch on the mechanical properties of polypropylene-oil palm empty fruit bunch-glass fibre hybrid composites. Polym. Plast. Technol. Eng. 2001, 40, 103-115. [CrossRef]

76. Hashim, M.K.R.; Abdul Majid, M.S.; Jamir, M.R.M.; Kasim, F.H.; Sultan, M.T.H. The Effect of Stacking Sequence and Ply Orientation on the Mechanical Properties of Pineapple Leaf Fibre (PALF)/Carbon Hybrid Laminate Composites. Polymers 2021, 13, 455. [CrossRef]

77. Siakeng, R.; Jawaid, M.; Asim, M.; Saba, N.; Sanjay, M.R.; Siengchin, S.; Fouad, H. Alkali treated coir/pineapple leaf fibres reinforced PLA hybrid composites: Evaluation of mechanical, morphological, thermal and physical properties. XPRESS Polym. Lett. 2020, 14, 717-730. [CrossRef]

78. Zin, M.H.; Abdan, K.; Mazlan, N.; Zainudin, E.S.; Liew, K.E.; Norizan, M.N. Automated spray up process for Pineapple Leaf Fibre hybrid biocomposites. Compos. Part. B Eng. 2019, 177, 107306. [CrossRef]

79. Venkata Deepthi, P.; Sita Rama Raju, K.; Indra Reddy, M. Dynamic mechanical analysis of banana, pineapple leaf and glass fibre reinforced hybrid polyester composites. Mater. Today Proc. 2019, 18, 2114-2117. [CrossRef]

80. Asim, M.; Paridah, M.T.; Saba, N.; Jawaid, M.; Alothman, O.Y.; Nasir, M.; Almutairi, Z. Thermal, physical properties and flammability of silane treated kenaf/pineapple leaf fibres phenolic hybrid composites. Compos. Struct. 2018, 202, 1330-1338. [CrossRef]

81. Sathees Kumar, S.; Muthalagu, R.; Nithin Chakravarthy, C. Effects of fiber loading on mechanical characterization of pineapple leaf and sisal fibers reinforced polyester composites for various applications. Mater. Today Proc. 2021, 44, 546-553. [CrossRef] 
82. Osorio, L.; Trujillo, E.; Van Vuure, A.W.; Verpoest, I. Morphological aspects and mechanical properties of single bamboo fibers and flexural characterization of bamboo/epoxy composites. J. Reinf. Plast. Compos. 2011, 30, 396-408. [CrossRef]

83. Nayak, S.K.; Mohanty, S.; Samal, S.K. Influence of short bamboo/glass fiber on the thermal, dynamic mechanical and rheological properties of polypropylene hybrid composites. Mater. Sci. Eng. A 2009, 523, 32-38. [CrossRef]

84. Samal, S.K.; Mohanty, S.; Nayak, S.K. Polypropylene bamboo/glass fiber hybrid composites: Fabrication and analysis of mechanical, morphological, thermal, and dynamic mechanical behavior. J. Reinf. Plast. Compos. 2009, 28, 2729-2747. [CrossRef]

85. Thwe, M.M.; Liao, K. Environmental effects on bamboo-glass/polypropylene hybrid composites. J. Mater. Sci. 2003, 38, 363-376. [CrossRef]

86. Thwe, M.M.; Liao, K. Durability of bamboo-glass fiber reinforced polymer matrix hybrid composites. Compos. Sci. Technol. 2003, 63, 375-387. [CrossRef]

87. Biswas, S.; Satapathy, A.; Patnaik, A. Effect of ceramic Fillers On Mechanical Properties of Bamboo Fiber Reinforced Epoxy Composites: A Comparative Study. In Proceedings of the Advanced Materials Research; Trans Tech Publications Ltd.: Freienbach, Switzerland, 2010; Volume 123, pp. 1031-1034.

88. Krishnan, G.S.; Velmurugan, P. Investigation on the characteristics of bamboo/jute reinforced hybrid epoxy polymer composites. Mater. Res. Express 2019, 6, 105346.

89. Shukla, R.; Srivastava, A.K. FTIR analysis of Bamboo and Flax (BFBF) Mat Reinforced Epoxy Hybrid Composite. Int. J. Sci. Res. Sci. Eng. Technol. 2019, 6, 119-124.

90. Getu, D.; Nallamothu, R.B.; Masresha, M.; Nallamothu, S.K.; Nallamothu, A.K. Production and characterization of bamboo and sisal fiber reinforced hybrid composite for interior automotive body application. Mater. Today Proc. 2021, 38, 2853-2860. [CrossRef]

91. Aruchamy, K.; Pavayee Subramani, S.; Palaniappan, S.K.; Sethuraman, B.; Velu Kaliyannan, G. Study on mechanical characteristics of woven cotton/bamboo hybrid reinforced composite laminates. J. Mater. Res. Technol. 2020, 9, 718-726. [CrossRef]

92. Olaniran, O.; Uwaifo, O.; Bamidele, E.; Olaniran, B. An investigation of the mechanical properties of organic silica, bamboo leaf ash and rice husk reinforced aluminium hybrid composite. Mater. Sci. Eng. Int. J. 2019, 3, 129-134. [CrossRef]

93. Sarkar, B.K.; Ray, D. Effect of the defect concentration on the impact fatigue endurance of untreated and alkali treated jutevinylester composites under normal and liquid nitrogen atmosphere. Compos. Sci. Technol. 2004, 64, 2213-2219. [CrossRef]

94. Ramana, M.V.; Ramprasad, S. Experimental investigation on jute/carbon fibre reinforced epoxy based hybrid composites. Mater. Today Proc. 2017, 4, 8654-8664. [CrossRef]

95. Ahmed, K.S.; Vijayarangan, S.; Naidu, A.C.B. Elastic properties, notched strength and fracture criterion in untreated woven jute-glass fabric reinforced polyester hybrid composites. Mater. Des. 2007, 28, 2287-2294. [CrossRef]

96. Tezara, C.; Zalinawati, M.; Siregar, J.P.; Jaafar, J.; Hamdan, M.H.M.; Oumer, A.N.; Chuah, K.H. Effect of Stacking Sequences, Fabric Orientations, and Chemical Treatment on the Mechanical Properties of Hybrid Woven Jute-Ramie Composites. Int. J. Precis. Eng. Manuf. Technol. 2021, 8, 1-13. [CrossRef]

97. Pandita, S.D.; Yuan, X.; Manan, M.A.; Lau, C.H.; Subramanian, A.S.; Wei, J. Evaluation of jute/glass hybrid composite sandwich: Water resistance, impact properties and life cycle assessment. J. Reinf. Plast. Compos. 2014, 33, 14-25. [CrossRef]

98. Akil, H.M.; Santulli, C.; Sarasini, F.; Tirillò, J.; Valente, T. Environmental effects on the mechanical behaviour of pultruded jute/glass fibre-reinforced polyester hybrid composites. Compos. Sci. Technol. 2014, 94, 62-70. [CrossRef]

99. Chaudhary, V.; Bajpai, P.K.; Maheshwari, S. Studies on mechanical and morphological characterization of developed jute/hemp/flax reinforced hybrid composites for structural applications. J. Nat. Fibers 2018, 15, 80-97. [CrossRef]

100. Joseph, K.; De Carvalho, L.H. Jute/cotton woven Fabric Reinforced Polyester Composites: Effect of Hybridization. In Proceedings of the ISNaPol/2000: Third International Symposium on Natural Polymers and Composites and the Workshop on Progress in Production and Processing of Cellulosic Fibres and Natural Polymers; Embrapa Instrumentação Agropecuária: Sao Carlos, Brazil, 2000; pp. 454-459.

101. Prasath, K.A.; Krishnan, B.R.; Arun, C.K. Mechanical properties of woven fabric Basalt/jute fibre reinforced polymer hybrid composites. Int. J. Mech. Eng. 2013, 2, 279-290.

102. Ramesh, M.; Deepa, C.; Arpitha, G.R.; Gopinath, V. Effect of hybridization on properties of hemp-carbon fibre-reinforced hybrid polymer composites using experimental and finite element analysis. World J. Eng. 2019, 16, 248-259. [CrossRef]

103. Thiagamani, S.M.K.; Krishnasamy, S.; Muthukumar, C.; Tengsuthiwat, J.; Nagarajan, R.; Siengchin, S.; Ismail, S.O. Investigation into mechanical, absorption and swelling behaviour of hemp/sisal fibre reinforced bioepoxy hybrid composites: Effects of stacking sequences. Int. J. Biol. Macromol. 2019, 140, 637-646. [CrossRef]

104. Haq, M.; Burgueño, R.; Mohanty, A.K.; Misra, M. Hybrid bio-based composites from blends of unsaturated polyester and soybean oil reinforced with nanoclay and natural fibers. Compos. Sci. Technol. 2008, 68, 3344-3351. [CrossRef]

105. Pappu, A.; Pickering, K.L.; Thakur, V.K. Manufacturing and characterization of sustainable hybrid composites using sisal and hemp fibres as reinforcement of poly(lactic acid) via injection moulding. Ind. Crop. Prod. 2019, 137, 260-269. [CrossRef]

106. Sarasini, F.; Tirillò, J.; Sergi, C.; Seghini, M.C.; Cozzarini, L.; Graupner, N. Effect of basalt fibre hybridisation and sizing removal on mechanical and thermal properties of hemp fibre reinforced HDPE composites. Compos. Struct. 2018, 188, 394-406. [CrossRef]

107. Ahmad, M.A.A.; Abdul Majid, M.S.; Ridzuan, M.J.M.; Mazlee, M.N.; Gibson, A.G. Dynamic mechanical analysis and effects of moisture on mechanical properties of interwoven hemp/polyethylene terephthalate (PET) hybrid composites. Constr. Build. Mater. 2018, 179, 265-276. [CrossRef] 
108. Paturel, A.; Dhakal, H.N. Influence of water absorption on the low velocity falling weight impact damage behaviour of flax/glass reinforced vinyl ester hybrid composites. Molecules 2020, 25, 278. [CrossRef]

109. Arbelaiz, A.; Fernandez, B.; Ramos, J.A.; Mondragon, I. Thermal and crystallization studies of short flax fibre reinforced polypropylene matrix composites: Effect of treatments. Thermochim. Acta 2006, 440, 111-121. [CrossRef]

110. Di Landro, L.; Lorenzi, W. Static and dynamic properties of thermoplastic matrix/natural fiber composites. J. Biobased Mater. Bioenergy 2009, 3, 238-244. [CrossRef]

111. Liu, Q.; Hughes, M. The fracture behaviour and toughness of woven flax fibre reinforced epoxy composites. Compos. Part. A Appl. Sci. Manuf. 2008, 39, 1644-1652. [CrossRef]

112. Almansour, F.A.; Dhakal, H.N.; Zhang, Z.Y. Investigation into Mode II interlaminar fracture toughness characteristics of flax/basalt reinforced vinyl ester hybrid composites. Compos. Sci. Technol. 2018, 154, 117-127. [CrossRef]

113. Cheour, K.; Assarar, M.; Scida, D.; Ayad, R.; Gong, X.-L. Long-term immersion in water of flax-glass fibre hybrid composites: Effect of stacking sequence on the mechanical and damping properties. Fibers Polym. 2020, 21, 162-169. [CrossRef]

114. Arulmurugan, M.; Selvakumar, A.S.; Prabu, K.; Rajamurugan, G. Effect of barium sulphate on mechanical, DMA and thermal behaviour of woven aloevera/flax hybrid composites. Bull. Mater. Sci. 2020, 43, 58. [CrossRef]

115. Xu, H.; Wang, L.; Teng, C.; Yu, M. Biodegradable composites: Ramie fibre reinforced PLLA-PCL composite prepared by in situ polymerization process. Polym. Bull. 2008, 61, 663-670. [CrossRef]

116. Romanzini, D.; Ornaghi Junior, H.L.; Amico, S.C.; Zattera, A.J. Preparation and characterization of ramie-glass fiber reinforced polymer matrix hybrid composites. Mater. Res. 2012, 15, 415-420. [CrossRef]

117. Marsyahyo, E.; Jamasri; Rochardjo, H.S.B.; Soekrisno. Preliminary investigation on bulletproof panels made from ramie fiber reinforced composites for NIJ level II, IIA, and IV. J. Ind. Text. 2009, 39, 13-26. [CrossRef]

118. Wen, L.E.I.; LEI, W.; Chao, R.E.N. Effect of volume fraction of ramie cloth on physical and mechanical properties of ramie cloth/UP resin composite. Trans. Nonferrous Met. Soc. China 2006, 16, s474-s477.

119. Bledzki, A.K.; Mamun, A.A.; Faruk, O. Abaca fibre reinforced PP composites and comparison with jute and flax fibre PP composites. Express Polym. Lett. 2007. [CrossRef]

120. Savastano, H., Jr.; Santos, S.F.; Radonjic, M.; Soboyejo, W.O. Fracture and fatigue of natural fiber-reinforced cementitious composites. Cem. Concr. Compos. 2009, 31, 232-243. [CrossRef]

121. Bledzki, A.K.; Mamun, A.A.; Jaszkiewicz, A.; Erdmann, K. Polypropylene composites with enzyme modified abaca fibre. Compos. Sci. Technol. 2010, 70, 854-860. [CrossRef]

122. Ortega, Z.; Monzón, M.D.; Benítez, A.N.; Kearns, M.; McCourt, M.; Hornsby, P.R. Banana and abaca fiber-reinforced plastic composites obtained by rotational molding process. Mater. Manuf. Process. 2013, 28, 879-883. [CrossRef]

123. Prasad, N.; Agarwal, V.K.; Sinha, S. Banana fiber reinforced low-density polyethylene composites: Effect of chemical treatment and compatibilizer addition. Iran. Polym. J. 2016, 25, 229-241. [CrossRef]

124. Agung, E.H.; Sapuan, S.M.; Hamdan, M.M.; Zaman, H.; Mustofa, U. Optimization of the mechanical properties of abaca fibre-reinforced high impact polystyrene (HIPS) composites using box-behnken design of experiments. Polym. Polym. Compos. 2011, 19, 697-710. [CrossRef]

125. Iqbal, M.; Aminanda, Y.; Firsa, T.; Ali, M. Bending Strength of Polyester Composites Reinforced with Stitched Random Orientation And Plain Weave Abaca Fiber. In Proceedings of the IOP Conference Series: Materials science and Engineering; IOP Publishing: Bristol, UK, 2020; Volume 739, p. 12035.

126. Rana, R.S.; Rana, S.; Nigrawal, A. Preparation and mechanical properties evaluation of polyvinyl alcohol and banana fibres composite. Mater. Today Proc. 2020, 26, 3145-3147. [CrossRef]

127. Zhong, L.X.; Fu, S.Y.; Zhou, X.S.; Zhan, H.Y. Effect of surface microfibrillation of sisal fibre on the mechanical properties of sisal/aramid fibre hybrid composites. Compos. Part. A Appl. Sci. Manuf. 2011, 42, 244-252. [CrossRef]

128. Asaithambi, B.; Ganesan, G.; Ananda Kumar, S. Bio-composites: Development and mechanical characterization of banana/sisal fibre reinforced poly lactic acid (PLA) hybrid composites. Fibers Polym. 2014, 15, 847-854. [CrossRef]

129. Noorunnisa Khanam, P.; Abdul Khalil, H.P.S.; Jawaid, M.; Ramachandra Reddy, G.; Surya Narayana, C.; Venkata Naidu, S. Sisal/Carbon Fibre Reinforced Hybrid Composites: Tensile, Flexural and Chemical Resistance Properties. J. Polym. Environ. 2010, 18, 727-733. [CrossRef]

130. Aslan, M.; Tufan, M.; Küçükömeroğlu, T. Tribological and mechanical performance of sisal-filled waste carbon and glass fibre hybrid composites. Compos. Part. B Eng. 2018, 140, 241-249. [CrossRef]

131. Gupta, M.K. Effect of frequencies on dynamic mechanical properties of hybrid jute/sisal fibre reinforced epoxy composite. Adv. Mater. Process. Technol. 2017, 3, 651-664. [CrossRef]

132. Sapuan, S.M.; Ishak, M.R.; Leman, Z.; Huzaifah, M.R.M.; Ilyas, R.A.; Ammar, I.M.; Ishak, M.H.A.; Yana, I. Pokok Enau: Potensi Dan Pembangunan Produk, 1st ed.; Sapuan, S.M., Ed.; Penerbit Universiti Putra Malaysia: Serdang, Selangor, 2017 ; ISBN 9789673447473.

133. Ishak, M.R.; Sapuan, S.M.; Leman, Z.; Rahman, M.Z.A.A.; Anwar, U.M.K.K.; Siregar, J.P. Sugar palm (Arenga pinnata): Its fibres, polymers and composites. Carbohydr. Polym. 2013, 91, 699-710. [CrossRef]

134. Ilyas, R.A.; Sapuan, S.M.; Ishak, M.R.; Zainudin, E.S. Sugar palm nanofibrillated cellulose (Arenga pinnata (Wurmb.) Merr): Effect of cycles on their yield, physic-chemical, morphological and thermal behavior. Int. J. Biol. Macromol. 2019, 123, 379-388. [CrossRef] 
135. Ilyas, R.A.; Sapuan, S.M.; Ishak, M.R. Isolation and characterization of nanocrystalline cellulose from sugar palm fibres (Arenga Pinnata). Carbohydr. Polym. 2018, 181, 1038-1051. [CrossRef]

136. Ilyas, R.A.; Sapuan, S.M.; Ibrahim, R.; Abral, H.; Ishak, M.R.; Zainudin, E.S.; Asrofi, M.; Atikah, M.S.N.; Huzaifah, M.R.M.; Radzi, A.M.; et al. Sugar palm (Arenga pinnata (Wurmb.) Merr) cellulosic fibre hierarchy: A comprehensive approach from macro to nano scale. J. Mater. Res. Technol. 2019, 8, 2753-2766. [CrossRef]

137. Norizan, M.N.; Abdan, K.; Ilyas, R.A.; Biofibers, S.P. Effect of fiber orientation and fiber loading on the mechanical and thermal properties of sugar palm yarn fiber reinforced unsaturated polyester resin composites. Polimery 2020, 65, 34-43. [CrossRef]

138. Nurazzi, N.M.; Khalina, A.; Sapuan, S.M.; Ilyas, R.A.; Rafiqah, S.A.; Hanafee, Z.M. Thermal properties of treated sugar palm yarn/glass fiber reinforced unsaturated polyester hybrid composites. J. Mater. Res. Technol. 2020, 9, 1606-1618. [CrossRef]

139. Ilyas, R.A.; Sapuan, S.M.; Ishak, M.R.; Zainudin, E.S. Effect of delignification on the physical, thermal, chemical, and structural properties of sugar palm fibre. BioResources 2017, 12, 8734-8754. [CrossRef]

140. Ilyas, R.A.; Sapuan, S.M.; Atikah, M.S.N.; Asyraf, M.R.M.; Rafiqah, S.A.; Aisyah, H.A.; Nurazzi, N.M.; Norrrahim, M.N.F. Effect of hydrolysis time on the morphological, physical, chemical, and thermal behavior of sugar palm nanocrystalline cellulose (Arenga pinnata (Wurmb.) Merr). Text. Res. J. 2021, 91, 152-167. [CrossRef]

141. Sahari, J.; Sapuan, S.M.; Zainudin, E.S.; Maleque, M.A. Physico-chemical and thermal properties of starch derived from sugar palm tree (Arenga pinnata). Asian J. Chem. 2014, 26, 955-959. [CrossRef]

142. Sanyang, M.L.; Sapuan, S.M.; Jawaid, M.; Ishak, M.R.; Sahari, J. Effect of plasticizer type and concentration on physical properties of biodegradable films based on sugar palm (arenga pinnata) starch for food packaging. J. Food Sci. Technol. 2016, 53, 326-336. [CrossRef] [PubMed]

143. Ilyas, R.A.; Sapuan, S.M.; Ishak, M.R.; Zainudin, E.S. Sugar palm nanocrystalline cellulose reinforced sugar palm starch composite: Degradation and water-barrier properties. IOP Conf. Ser. Mater. Sci. Eng. 2018, 368, 012006. [CrossRef]

144. Ilyas, R.A.; Sapuan, S.M.; Ishak, M.R.; Zainudin, E.S. Development and characterization of sugar palm nanocrystalline cellulose reinforced sugar palm starch bionanocomposites. Carbohydr. Polym. 2018, 202, 186-202. [CrossRef]

145. Ilyas, R.A.; Sapuan, S.M.; Ishak, M.R.; Zainudin, E.S. Water transport properties of bio-nanocomposites reinforced by sugar palm (Arenga Pinnata) nanofibrillated cellulose. J. Adv. Res. Fluid Mech. Therm. Sci. J. 2018, 51, 234-246.

146. Nazrin, A.; Sapuan, S.M.; Zuhri, M.Y.M.; Tawakkal, I.S.M.A.; Ilyas, R.A. Water barrier and mechanical properties of sugar palm crystalline nanocellulose reinforced thermoplastic sugar palm starch (TPS)/poly(lactic acid) (PLA) blend bionanocomposites. Nanotechnol. Rev. 2021, 10, 431-442. [CrossRef]

147. Ilyas, R.A.; Sapuan, S.M.; Atiqah, A.; Ibrahim, R.; Abral, H.; Ishak, M.R.; Zainudin, E.S.; Nurazzi, N.M.; Atikah, M.S.N.; Ansari, M.N.M.; et al. Sugar palm (Arenga pinnata [Wurmb.] Merr) starch films containing sugar palm nanofibrillated cellulose as reinforcement: Water barrier properties. Polym. Compos. 2020, 41, 459-467. [CrossRef]

148. Hazrol, M.D.; Sapuan, S.M.; Ilyas, R.A.; Othman, M.L.; Sherwani, S.F.K. Electrical properties of sugar palm nanocrystalline cellulose reinforced sugar palm starch nanocomposites. Polimery 2020, 65, 363-370. [CrossRef]

149. Atikah, M.S.N.; Ilyas, R.A.; Sapuan, S.M.; Ishak, M.R.; Zainudin, E.S.; Ibrahim, R.; Atiqah, A.; Ansari, M.N.M.; Jumaidin, R. Degradation and physical properties of sugar palm starch/sugar palm nanofibrillated cellulose bionanocomposite. Polimery 2019, 64, 680-689. [CrossRef]

150. Ilyas, R.A.; Sapuan, S.M.; Ibrahim, R.; Abral, H.; Ishak, M.R.; Zainudin, E.S.; Atiqah, A.; Atikah, M.S.N.; Syafri, E.; Asrofi, M.; et al Thermal, Biodegradability and Water Barrier Properties of Bio-Nanocomposites Based on Plasticised Sugar Palm Starch and Nanofibrillated Celluloses from Sugar Palm Fibres. J. Biobased Mater. Bioenergy 2020, 14, 234-248. [CrossRef]

151. Ilyas, R.A.; Sapuan, S.M.; Ibrahim, R.; Abral, H.; Ishak, M.R.; Zainudin, E.S.; Atikah, M.S.N.; Mohd Nurazzi, N.; Atiqah, A.; Ansari, M.N.M.; et al. Effect of sugar palm nanofibrillated cellulose concentrations on morphological, mechanical and physical properties of biodegradable films based on agro-waste sugar palm (Arenga pinnata (Wurmb.) Merr) starch. J. Mater. Res. Technol. 2019, 8, 4819-4830. [CrossRef]

152. Suriani, M.J.; Sapuan, S.M.; Ruzaidi, C.M.; Nair, D.S.; Ilyas, R.A. Flammability, morphological and mechanical properties of sugar palm fiber/polyester yarn-reinforced epoxy hybrid biocomposites with magnesium hydroxide flame retardant filler. Text. Res. J. 2021. [CrossRef]

153. Ishak, M.R.; Leman, Z.; Sapuan, S.M.; Salleh, M.Y.; Misri, S. Effect of Sea Water Treatment on the Impact and Flexural Strength of Sugar Palm Fibre Reinforced Epoxy Composites. Int. J. Mech. Mater. Eng. (IJMME) 2009, 4, 316-320.

154. Sanyang, M.L.; Sapuan, S.M.; Jawaid, M.; Ishak, M.R.; Sahari, J. Recent developments in sugar palm (Arenga pinnata) based biocomposites and their potential industrial applications: A review. Renew. Sustain. Energy Rev. 2016, 54, 533-549. [CrossRef]

155. Leman, Z.; Sastra, H.Y.; Sapuan, S.M.; Hamdan, M.M.H.M.; Maleque, M.A. Study on impact properties of Arenga pinnata fibre reinforced epoxy composites. J. Appl. Technol. 2005, 3, 14-19.

156. Bachtiar, D.; Sapuan, S.M.; Hamdan, M.M. Flexural properties of alkaline treated sugar palm fibre reinforced epoxy composites. Int. J. Automot. Mech. Eng. 2010, 1, 79-90. [CrossRef]

157. Ishak, M.R.; Sapuan, S.M.; Leman, Z.; Rahman, M.Z.A.; Anwar, U.M.K. Characterization of sugar palm (Arenga pinnata) fibres. J. Therm. Anal. Calorim. 2012, 109, 981-989. [CrossRef]

158. Nurazzi, N.M.; Harussani, M.M.; Zulaikha, N.D.S.; Norhana, A.H.; Syakir, M.I.; Norli, A. Composites based on conductive polymer with carbon nanotubes in DMMP gas sensors-An overview. Polimery 2021, 66, 85-97. [CrossRef] 
159. Rozilah, A.; Jaafar, C.N.A.; Sapuan, S.M.; Zainol, I.; Ilyas, R.A. The Effects of Silver Nanoparticles Compositions on the Mechanical, Physiochemical, Antibacterial, and Morphology Properties of Sugar Palm Starch Biocomposites for Antibacterial Coating. Polymers 2020, 12, 2605. [CrossRef]

160. Atiqah, A.; Jawaid, M.; Sapuan, S.M.; Ishak, M.R.; Alothman, O.Y. Thermal Properties of Sugar Palm/Glass Fiber Reinforced Thermoplastic Polyurethane hybrid composites. Compos. Struct. 2018. [CrossRef]

161. Atiqah, A.; Jawaid, M.; Sapuan, S.M.; Ishak, M.R.; Ansari, M.N.M.; Ilyas, R.A. Physical and thermal properties of treated sugar palm/glass fibre reinforced thermoplastic polyurethane hybrid composites. J. Mater. Res. Technol. 2019, 8, 3726-3732. [CrossRef]

162. Nishino, T.; Hirao, K.; Kotera, M.; Nakamae, K.; Inagaki, H. Kenaf reinforced biodegradable composite. Compos. Sci. Technol. 2003, 63, 1281-1286. [CrossRef]

163. Nor, A.F.M.; Hassan, M.Z.; Rasid, Z.A.; Aziz, S.A.; Sarip, S.; Md Daud, M.Y. Optimization on Tensile Properties of Kenaf/Multiwalled CNT Hybrid Composites with Box-Behnken Design. Appl. Compos. Mater. 2021, 28, 607-632. [CrossRef]

164. Du, Y.; Zhang, J.; Yu, J.; Lacy, T.E., Jr.; Xue, Y.; Toghiani, H.; Horstemeyer, M.F.; Pittman, C.U., Jr. Kenaf bast fiber bundle-reinforced unsaturated polyester composites. IV: Effects of fiber loadings and aspect ratios on composite tensile properties. For. Prod. J. 2010, 60, 582-591. [CrossRef]

165. Bonnia, N.N.; Ahmad, S.H.; Zainol, I.; Mamun, A.A.; Beg, M.D.H.; Bledzki, A.K. Mechanical properties and environmental stress cracking resistance of rubber toughened polyester/kenaf composite. Express Polym. Lett 2010, 4, 55-61. [CrossRef]

166. Sreekala, M.S.; Kumaran, M.G.; Thomas, S. Stress relaxation behaviour in oil palm fibres. Mater. Lett. 2001, 50, 263-273. [CrossRef]

167. Agarwal, R.; Saxena, N.S.; Sharma, K.B.; Thomas, S.; Sreekala, M.S. Effect of different treatments on the thermal behavior of reinforced phenol-formaldehyde polymer composites. J. Appl. Polym. Sci. 2000, 78, 603-608. [CrossRef]

168. Norrrahim, M.N.F.; Huzaifah, M.R.M.; Farid, M.A.A.; Shazleen, S.S.; Misenan, M.S.M.; Yasim-Anuar, T.A.T.; Naveen, J.; Nurazzi, N.M.; Rani, M.S.A.; Hakimi, M.I.; et al. Greener Pretreatment Approaches for the Valorisation of Natural Fibre Biomass into Bioproducts. Polymers 2021, 13, 2971. [CrossRef]

169. Khalid, M.; Ratnam, C.T.; Chuah, T.G.; Ali, S.; Choong, T.S.Y. Comparative study of polypropylene composites reinforced with oil palm empty fruit bunch fiber and oil palm derived cellulose. Mater. Des. 2008, 29, 173-178. [CrossRef]

170. Khalil, H.P.S.A.; Issam, A.M.; Shakri, M.T.A.; Suriani, R.; Awang, A.Y. Conventional agro-composites from chemically modified fibres. Ind. Crop. Prod. 2007, 26, 315-323. [CrossRef]

171. Kaddami, H.; Dufresne, A.; Khelifi, B.; Bendahou, A.; Taourirte, M.; Raihane, M.; Issartel, N.; Sautereau, H.; Gerard, J.-F.; Sami, N. Short palm tree fibers-Thermoset matrices composites. Compos. Part. A Appl. Sci. Manuf. 2006, 37, 1413-1422. [CrossRef]

172. Amor, I.B.; Rekik, H.; Kaddami, H.; Raihane, M.; Arous, M.; Kallel, A. Studies of dielectric relaxation in natural fiber-polymer composites. J. Electrostat. 2009, 67,717-722. [CrossRef]

173. Threepopnatkul, P.; Kaerkitcha, N.; Athipongarporn, N. Polycarbonate with pineapple leaf fiber to produce functional composites. In Proceedings of the Advanced Materials Research; Trans Tech Publisher: Bristol, UK, 2008; Volume 47, pp. 674-677.

174. Norizan, M.N.; Moklis, M.H.; Alias, A.H.; Rushdan, A.I.; Norrrahim, M.N.F.; Abdan, K.; Abdullah, N. Treatments of Natural Fibre as Reinforcement in Polymer Composites-Short Review. Funct. Compos. Struct. 2021, 3, 024002. [CrossRef]

175. Mangal, R.; Saxena, N.S.; Sreekala, M.S.; Thomas, S.; Singh, K. Thermal properties of pineapple leaf fiber reinforced composites. Mater. Sci. Eng. A 2003, 339, 281-285. [CrossRef]

176. Mishra, S.; Misra, M.; Tripathy, S.S.; Nayak, S.K.; Mohanty, A.K. Potentiality of pineapple leaf fibre as reinforcement in PALFpolyester composite: Surface modification and mechanical performance. J. Reinf. Plast. Compos. 2001, 20, 321-334. [CrossRef]

177. Shih, Y. Mechanical and thermal properties of waste water bamboo husk fiber reinforced epoxy composites. Mater. Sci. Eng. A 2007, 446, 289-295. [CrossRef]

178. Lopattananon, N.; Panawarangkul, K.; Sahakaro, K.; Ellis, B. Performance of pineapple leaf fiber-natural rubber composites: The effect of fiber surface treatments. J. Appl. Polym. Sci. 2006, 102, 1974-1984. [CrossRef]

179. Saidane, E.H.; Scida, D.; Pac, M.-J.; Ayad, R. Mode-I interlaminar fracture toughness of flax, glass and hybrid flax-glass fibre woven composites: Failure mechanism evaluation using acoustic emission analysis. Polym. Test. 2019, 75, 246-253. [CrossRef]

180. Arun, P.V.R.; Rajadurai, A. Inter laminar shear strength behavior of acid, base and silane treated E-glass fibre epoxy resin composites on drilling process. Def. Technol. 2017, 13, 40-46. [CrossRef]

181. Suriani, M.J.; Rapi, H.Z.; Ilyas, R.A.; Petrů, M.; Sapuan, S.M. Delamination and Manufacturing Defects in Natural Fiber-Reinforced Hybrid Composite: A Review. Polymers 2021, 13, 1323. [CrossRef]

182. Riccio, A. Delamination in the context of composite structural design. Delamination Behav. Compos. A Vol. Woodhead Publ. Ser. Compos. Sci. Eng. 2008, 28-64. [CrossRef]

183. Chermoshentseva, A.S.; Pokrovskiy, A.M.; Bokhoeva, L.A. The behavior of delaminations in composite materials—Experimental results. IOP Conf. Ser. Mater. Sci. Eng. 2016, 116. [CrossRef]

184. Khan, S.U.; Kim, J.K. Impact and delamination failure of multiscale carbon nanotube-fiber reinforced polymer composites: A review. Int. J. Aeronaut. Sp. Sci. 2011, 12, 115-133. [CrossRef]

185. Kim, J.; Technology, M.S.-C.S. Undefined Impact and Delamination Failure of Woven-Fabric Composites; Elsevier: Amsterdam, The Netherlands, 2020.

186. Dhanawade, A.; Kumar, S. Experimental study of delamination and kerf geometry of carbon epoxy composite machined by abrasive water jet. J. Compos. Mater. 2017, 51, 3373-3390. [CrossRef] 
187. Senthilkumar, K.; Saba, N.; Chandrasekar, M.; Jawaid, M.; Rajini, N.; Alothman, O.Y.; Siengchin, S. Evaluation of mechanical and free vibration properties of the pineapple leaf fibre reinforced polyester composites. Constr. Build. Mater. 2019, 195, $423-431$. [CrossRef]

188. Feng, N.L.; Malingam, S.D.; Razali, N.; Subramonian, S. Alkali and Silane Treatments towards Exemplary Mechanical Properties of Kenaf and Pineapple Leaf Fibre-reinforced Composites. J. Bionic Eng. 2020, 17, 380-392. [CrossRef]

189. Shah, D.U.; Konnerth, J.; Ramage, M.H.; Gusenbauer, C. Mapping thermal conductivity across bamboo cell walls with scanning thermal microscopy. Sci. Rep. 2019, 9, 1-8. [CrossRef] [PubMed]

190. Zakikhani, P.; Zahari, R.; Sultan, M.T.H.; Majid, D.L. Extraction and preparation of bamboo fibre-reinforced composites. Mater. Des. 2014, 63, 820-828. [CrossRef]

191. Azammi, A.M.N.; Ilyas, R.A.; Sapuan, S.M.; Ibrahim, R.; Atikah, M.S.N.; Asrofi, M.; Atiqah, A. Characterization Studies Of Biopolymeric Matrix And Cellulose Fibres Based Composites Related To Functionalized Fibre-Matrix Interface. In Interfaces in Particle and Fibre Reinforced Composites; Elsevier: London, UK, 2020; pp. 29-93, ISBN 9780081026656.

192. Thwe, M.M.; Liao, K. Effects of environmental aging on the mechanical properties of bamboo-glass fiber reinforced polymer matrix hybrid composites. Compos. Part. A Appl. Sci. Manuf. 2002, 33, 43-52. [CrossRef]

193. Ying-Chen, Z.; Hong-Yan, W.; Yi-Ping, Q. Morphology and properties of hybrid composites based on polypropylene/polylactic acid blend and bamboo fiber. Bioresour. Technol. 2010, 101, 7944-7950. [CrossRef]

194. Thyavihalli Girijappa, Y.G.; Mavinkere Rangappa, S.; Parameswaranpillai, J.; Siengchin, S. Natural Fibers as Sustainable and Renewable Resource for Development of Eco-Friendly Composites: A Comprehensive Review. Front. Mater. 2019, 6, 1-14. [CrossRef]

195. Ramesh, M.; Palanikumar, K.; Reddy, K.H. Plant fibre based bio-composites: Sustainable and renewable green materials. Renew. Sustain. Energy Rev. 2017, 79, 558-584. [CrossRef]

196. Lim, J.K. Stress corrosion cracking (SCC) in polymer composites. In Stress Corrosion Cracking; Elsevier: Amsterdam, The Netherlands, 2011; pp. 485-536.

197. Mohanty, A.K.; Khan, M.A.; Hinrichsen, G. Surface modification of jute and its influence on performance of biodegradable jute-fabric/Biopol composites. Compos. Sci. Technol. 2000, 60, 1115-1124. [CrossRef]

198. Zaman, H.U.; Khan, R.A.; Haque, M.E.; Khan, M.A.; Khan, A.; Huq, T.; Noor, N.; Rahman, M.; Mustafizur Rahman, K.; Huq, D. Preparation and mechanical characterization of jute reinforced polypropylene/natural rubber composite. J. Reinf. Plast. Compos. 2010, 29, 3064-3065. [CrossRef]

199. Acha, B.A.; Reboredo, M.M.; Marcovich, N.E. Creep and dynamic mechanical behavior of PP-jute composites: Effect of the interfacial adhesion. Compos. Part. A Appl. Sci. Manuf. 2007, 38, 1507-1516. [CrossRef]

200. Wang, X.; Cui, Y.; Xu, Q.; Xie, B.; Li, W. Effects of alkali and silane treatment on the mechanical properties of jute-fiber-reinforced recycled polypropylene composites. J. Vinyl Addit. Technol. 2010, 16, 183-188. [CrossRef]

201. Hong, C.K.; Hwang, I.; Kim, N.; Park, D.H.; Hwang, B.S.; Nah, C. Mechanical properties of silanized jute-polypropylene composites. J. Ind. Eng. Chem. 2008, 14, 71-76. [CrossRef]

202. Sampath, A.; Martin, G.C. Enhancement of Natural Fiber-Epoxy Interaction Using Bi-Functional Surface Modifiers (963). In Proceedings of the Technical Papers of the Annual Technical Conference; Society of Plastics Engineers (SPE) Incorporated: Danbury, CT, USA, 2000; Volume 2, pp. 2274-2278.

203. Dwivedi, U.K.; Chand, N. Influence of fibre orientation on friction and sliding wear behaviour of jute fibre reinforced polyester composite. Appl. Compos. Mater. 2009, 16, 93-100. [CrossRef]

204. Singh, B.; Gupta, M.; Verma, A. The durability of jute fibre-reinforced phenolic composites. Compos. Sci. Technol. 2000, 60, 581-589. [CrossRef]

205. Alves, C.; Ferrão, P.M.C.; Silva, A.J.; Reis, L.G.; Freitas, M.; Rodrigues, L.B.; Alves, D.E. Ecodesign of automotive components making use of natural jute fiber composites. J. Clean. Prod. 2010, 18, 313-327. [CrossRef]

206. Mir, A.; Zitoune, R.; Collombet, F.; Bezzazi, B. Study of mechanical and thermomechanical properties of jute/epoxy composite laminate. J. Reinf. Plast. Compos. 2010, 29, 1669-1680. [CrossRef]

207. Sarikanat, M. The influence of oligomeric siloxane concentration on the mechanical behaviors of alkalized jute/modified epoxy composites. J. Reinf. Plast. Compos. 2010, 29, 807-817. [CrossRef]

208. Fraga, A.N.; Frullloni, E.; De la Osa, O.; Kenny, J.M.; Vázquez, A. Relationship between water absorption and dielectric behaviour of natural fibre composite materials. Polym. Test. 2006, 25, 181-187. [CrossRef]

209. Santulli, C. Post-impact damage characterisation on natural fibre reinforced composites using acoustic emission. NDT E Int. 2001, 34, 531-536. [CrossRef]

210. Dash, B.N.; Rana, A.K.; Mishra, H.K.; Nayak, S.K.; Tripathy, S.S. Novel low-cost jute-polyester composites. III. Weathering and thermal behavior. J. Appl. Polym. Sci. 2000, 78, 1671-1679. [CrossRef]

211. Sever, K.; Sarikanat, M.; Seki, Y.; Erkan, G.; Erdoğan, Ü.H. The mechanical properties of $\gamma$-methacryloxypropyltrimethoxy silane-treated jute/polyester composites. J. Compos. Mater. 2010, 44, 1913-1924. [CrossRef]

212. Pracella, M.; Chionna, D.; Anguillesi, I.; Kulinski, Z.; Piorkowska, E. Functionalization, compatibilization and properties of polypropylene composites with hemp fibres. Compos. Sci. Technol. 2006, 66, 2218-2230. [CrossRef]

213. Li, Y.; Pickering, K.L. The effect of chelator and white rot fungi treatments on long hemp fibre-reinforced composites. Compos. Sci. Technol. 2009, 69, 1265-1270. [CrossRef] 
214. Li, Y.; Pickering, K.L. Hemp fibre reinforced composites using chelator and enzyme treatments. Compos. Sci. Technol. 2008, 68, 3293-3298. [CrossRef]

215. Li, Y.; Pickering, K.L.; Farrell, R.L. Determination of interfacial shear strength of white rot fungi treated hemp fibre reinforced polypropylene. Compos. Sci. Technol. 2009, 69, 1165-1171. [CrossRef]

216. Wang, C.; Zuo, Q.; Lin, T.; Anuar, N.I.S.; Mohd Salleh, K.; Gan, S.; Yousfani, S.H.S.; Zuo, H.; Zakaria, S. Predicting thermal conductivity and mechanical property of bamboo fibers/polypropylene nonwovens reinforced composites based on regression analysis. Int. Commun. Heat Mass Transf. 2020, 118, 104895. [CrossRef]

217. Amin, K.F.; Sharif, A.; Hoque, M.E. Bonding Mechanism and Interface Enhancement of Bamboo Fiber Reinforced Composites. In Bamboo Fiber Composites; Springer: Singapore, 2021; pp. 215-233.

218. Lobo, A.; Haseebuddin, M.R.; Harsha, S.; Acharya, K.G.; Balaji, G.; Pal, B. Mechanical behavior of disposed fiberglass filled bamboo mat reinforced polyester composite. Mater. Today Proc. 2021. [CrossRef]

219. de Araujo Alves Lima, R.; Kawasaki Cavalcanti, D.; de Souza e Silva Neto, J.; Meneses da Costa, H.; Banea, M.D. Effect of surface treatments on interfacial properties of natural intralaminar hybrid composites. Polym. Compos. 2020, 41, 314-325. [CrossRef]

220. Bourmaud, A.; Baley, C. Rigidity analysis of polypropylene/vegetal fibre composites after recycling. Polym. Degrad. Stab. 2009, 94, 297-305. [CrossRef]

221. Santulli, C.; Caruso, A.P. Effect of fibre architecture on the falling weight impact properties of hemp/epoxy composites. J. Biobased Mater. Bioenergy 2009, 3, 291-297. [CrossRef]

222. Cicala, G.; Cristaldi, G.; Recca, G.; Ziegmann, G.; El-Sabbagh, A.; Dickert, M. Properties and performances of various hybrid glass/natural fibre composites for curved pipes. Mater. Des. 2009, 30, 2538-2542. [CrossRef]

223. Scarponi, C.; Pizzinelli, C.S.; Sánchez-Sáez, S.; Barbero, E. Impact load behaviour of resin transfer moulding (RTM) hemp fibre composite laminates. J. Biobased Mater. Bioenergy 2009, 3, 298-310. [CrossRef]

224. Eichhorn, S.J.; Young, R.J. Composite micromechanics of hemp fibres and epoxy resin microdroplets. Compos. Sci. Technol. 2004, 64, 767-772. [CrossRef]

225. Hepworth, D.G.; Hobson, R.N.; Bruce, D.M.; Farrent, J.W. The use of unretted hemp fibre in composite manufacture. Compos. Part. A Appl. Sci. Manuf. 2000, 31, 1279-1283. [CrossRef]

226. Kunanopparat, T.; Menut, P.; Morel, M.-H.; Guilbert, S. Reinforcement of plasticized wheat gluten with natural fibers: From mechanical improvement to deplasticizing effect. Compos. Part. A Appl. Sci. Manuf. 2008, 39, 777-785. [CrossRef]

227. John, M.J.; Anandjiwala, R.D. Chemical modification of flax reinforced polypropylene composites. Compos. Part. A Appl. Sci. Manuf. 2009, 40, 442-448. [CrossRef]

228. Fiore, V.; Scalici, T.; Sarasini, F.; Tirilló, J.; Calabrese, L. Salt-fog spray aging of jute-basalt reinforced hybrid structures: Flexural and low velocity impact response. Compos. Part. B Eng. 2017, 116, 99-112. [CrossRef]

229. Oksman, K. Mechanical properties of natural fibre mat reinforced thermoplastic. Appl. Compos. Mater. 2000, 7, 403-414. [CrossRef]

230. Arbelaiz, A.; Fernández, B.; Cantero, G.; Llano-Ponte, R.; Valea, A.; Mondragon, I. Mechanical properties of flax fibre/polypropylene composites. Influence of fibre/matrix modification and glass fibre hybridization. Compos. Part. A Appl. Sci. Manuf. 2005, 36, 1637-1644. [CrossRef]

231. Duhovic, M.; Horbach, S.; Bhattacharyya, D. Improving the interface strength in flax fibre poly(lactic) acid composites. J. Biobased Mater. Bioenergy 2009, 3, 188-198. [CrossRef]

232. Van de Velde, K.; Kiekens, P. Effect of material and process parameters on the mechanical properties of unidirectional and multidirectional flax/polypropylene composites. Compos. Struct. 2003, 62, 443-448. [CrossRef]

233. Bos, H.L.; Müssig, J.; van den Oever, M.J.A. Mechanical properties of short-flax-fibre reinforced compounds. Compos. Part. A Appl. Sci. Manuf. 2006, 37, 1591-1604. [CrossRef]

234. Buttlar, H.B. Natural fibre reinforced construction materials for SMC applications. In Proceedings of the Conference RIKO-2005; Niedersachsen, German, 2005; pp. 1-24.

235. Stuart, T.; Liu, Q.; Hughes, M.; McCall, R.D.; Sharma, H.S.S.; Norton, A. Structural biocomposites from flax-Part I: Effect of bio-technical fibre modification on composite properties. Compos. Part. A Appl. Sci. Manuf. 2006, 37, 393-404. [CrossRef]

236. Van de Weyenberg, I.; Chi Truong, T.; Vangrimde, B.; Verpoest, I. Improving the properties of UD flax fibre reinforced composites by applying an alkaline fibre treatment. Compos. Part. A Appl. Sci. Manuf. 2006, 37, 1368-1376. [CrossRef]

237. Van de Weyenberg, I.; Ivens, J.; De Coster, A.; Kino, B.; Baetens, E.; Verpoest, I. Influence of processing and chemical treatment of flax fibres on their composites. Compos. Sci. Technol. 2003, 63, 1241-1246. [CrossRef]

238. Manfredi, L.B.; Rodríguez, E.S.; Wladyka-Przybylak, M.; Vázquez, A. Thermal degradation and fire resistance of unsaturated polyester, modified acrylic resins and their composites with natural fibres. Polym. Degrad. Stab. 2006, 91, 255-261. [CrossRef]

239. Baley, C.; Busnel, F.; Grohens, Y.; Sire, O. Influence of chemical treatments on surface properties and adhesion of flax fibrepolyester resin. Compos. Part. A Appl. Sci. Manuf. 2006, 37, 1626-1637. [CrossRef]

240. Yu, T.; Ren, J.; Li, S.; Yuan, H.; Li, Y. Effect of fiber surface-treatments on the properties of poly(lactic acid)/ramie composites. Compos. Part. A Appl. Sci. Manuf. 2010, 41, 499-505. [CrossRef]

241. Nam, S.; Netravali, A.N. Green composites. I. physical properties of ramie fibers for environment-friendly green composites. Fibers Polym. 2006, 7, 372-379. [CrossRef]

242. Ishikawa, A.; Okano, T.; Sugiyama, J. Fine structure and tensile properties of ramie fibres in the crystalline form of cellulose I., II, IIII and IVI. Polymers 1997, 38, 463-468. [CrossRef] 
243. Goda, K.; Sreekala, M.S.; Gomes, A.; Kaji, T.; Ohgi, J. Improvement of plant based natural fibers for toughening green compositesEffect of load application during mercerization of ramie fibers. Compos. Part. A Appl. Sci. Manuf. 2006, 37, 2213-2220. [CrossRef]

244. Ilyas, R.A.; Sapuan, S.M. Biopolymers and Biocomposites: Chemistry and Technology. Curr. Anal. Chem. 2020, 16, 500-503. [CrossRef]

245. Nurazzi, N.M.; Asyraf, M.R.M.; Khalina, A.; Abdullah, N.; Aisyah, H.A.; Rafiqah, S.A.; Sabaruddin, F.A.; Kamarudin, S.H.; Norrrahim, M.N.F.; Ilyas, R.A.; et al. A Review on Natural Fiber Reinforced Polymer Composite for Bullet Proof and Ballistic Applications. Polymers 2021, 13, 646. [CrossRef]

246. Ilyas, R.A.; Sapuan, S.M. The Preparation Methods and Processing of Natural Fibre Bio-polymer Composites. Curr. Org. Synth. 2020, 16, 1068-1070. [CrossRef]

247. Aisyah, H.A.; Paridah, M.T.; Sapuan, S.M.; Ilyas, R.A.; Khalina, A.; Nurazzi, N.M.; Lee, S.H.; Lee, C.H. A comprehensive review on advanced sustainable woven natural fibre polymer composites. Polymers 2021, 13, 471. [CrossRef]

248. Müssig, J. Cotton fibre-reinforced thermosets versus ramie composites: A comparative study using petrochemical-and agro-based resins. J. Polym. Environ. 2008, 16, 94-102. [CrossRef]

249. Lodha, P.; Netravali, A.N. Characterization of stearic acid modified soy protein isolate resin and ramie fiber reinforced 'green'composites. Compos. Sci. Technol. 2005, 65, 1211-1225. [CrossRef]

250. Kishi, H.; Fujita, A. Wood-based epoxy resins and the ramie fiber reinforced composites. Environ. Eng. Manag. J. 2008, 7, 517-523. [CrossRef]

251. Long, C.-G.; He, L.-P.; Zhong, Z.-H.; Chen, S.-G. Studies on the polypropylene composites reinforced by ramier fiber and K2Ti6O13 whisker. Res. Lett. Mater. Sci. 2007, 2007. [CrossRef]

252. Pothan, L.A.; Thomas, S.; Groeninckx, G. The role of fibre/matrix interactions on the dynamic mechanical properties of chemically modified banana fibre/polyester composites. Compos. Part. A Appl. Sci. Manuf. 2006, 37, 1260-1269. [CrossRef]

253. El-Meligy, M.G.; Mohamed, S.H.; Mahani, R.M. Study mechanical, swelling and dielectric properties of prehydrolysed banana fiber-Waste polyurethane foam composites. Carbohydr. Polym. 2010, 80, 366-372. [CrossRef]

254. Teramoto, N.; Urata, K.; Ozawa, K.; Shibata, M. Biodegradation of aliphatic polyester composites reinforced by abaca fiber. Polym. Degrad. Stab. 2004. [CrossRef]

255. Harussani, M.M.; Sapuan, S.M.; Khalina, A.; Rashid, U.; Tarique, J. Slow pyrolysis of disinfected COVID-19 non-woven polypropylene (PP) waste. In Proceedings of the International Symposium on Applied Sciences and Engineering ISASE2021; Office of International Affairs, Atatürk University: Erzurum, Turkey, 2021; pp. 310-312.

256. Zhong, J.B.; Lv, J.; Wei, C. Mechanical properties of sisal fibre reinforced urea formaldehyde resin composites. Express Polym. Lett. 2007, 1, 681-687. [CrossRef]

257. Senthilkumar, K.; Saba, N.; Rajini, N.; Chandrasekar, M.; Jawaid, M.; Siengchin, S.; Alotman, O.Y. Mechanical properties evaluation of sisal fibre reinforced polymer composites: A review. Constr. Build. Mater. 2018, 174, 713-729. [CrossRef]

258. Ilyas, R.A.; Sapuan, S.M.; Norrrahim, M.N.F.; Yasim-Anuar, T.A.T.; Kadier, A.; Kalil, M.S.; Atikah, M.S.N.; Ibrahim, R.; Asrofi, M.; Abral, H.; et al. Nanocellulose/starch biopolymer nanocomposites: Processing, manufacturing, and applications. In Advanced Processing, Properties, and Application of Strach and Other Bio-Based Polymer; Al-Oqla, F.M., Ed.; Elsevier Inc.: Amsterdam, The Netherlands, 2021.

259. Azammi, A.M.N.; Ilyas, R.A.; Sapuan, S.M.; Ibrahim, R.; Atikah, M.S.N.; Asrofi, M.; Atiqah, A. Characterization studies of biopolymeric matrix and cellulose fibres based composites related to functionalized fibre-matrix interface. In Interfaces in Particle and Fibre Reinforced Composites- From Macro to Nano Scales; Woodhead Publishing: London, UK, 2019; pp. 1-68, ISBN 9780081026656.

260. Faruk, O.; Bledzki, A.K.; Fink, H.-P.; Sain, M. Progress Report on Natural Fiber Reinforced Composites. Macromol. Mater. Eng. 2014, 299, 9-26. [CrossRef]

261. Ilyas, R.A.; Sapuan, S.M.; Asyraf, M.R.M.; Atikah, M.S.N.; Ibrahim, R.; Dele-Afolabi, T.T.; Hazrol, M.D. Introduction to BiofillerReinforced Degradable Polymer Composites. In Biofiller-Reinforced Biodegradable Polymer Composites; Jumaidin, R., Sapuan, S.M., Ismail, H., Eds.; CRC Press: Boca Raton, FL, USA, 2020; pp. 1-23.

262. Jumaidin, R.; Saidi, Z.A.S.; Ilyas, R.A.; Ahmad, M.N.; Wahid, M.K.; Yaakob, M.Y.; Maidin, N.A.; Rahman, M.H.A.; Osman, M.H. Characteristics of Cogon Grass Fibre Reinforced Thermoplastic Cassava Starch Biocomposite: Water Absorption and Physical Properties. J. Adv. Res. Fluid Mech. Therm. Sci. 2019, 62, 43-52.

263. Sreekumar. Matrices for Natural-Fibre Reinforced Composites; Woodhead Publishing Limited: Brimingham, UK, 2008; ISBN 9781845692674.

264. Suppakarn, N.; Jarukumjorn, K. Mechanical properties and flammability of sisal/PP composites: Effect of flame retardant type and content. Compos. Part. B Eng. 2009, 40, 613-618. [CrossRef]

265. Joseph, P.V.; Rabello, M.S.; Mattoso, L.H.C.; Joseph, K.; Thomas, S. Environmental effects on the degradation behaviour of sisal fibre reinforced polypropylene composites. Compos. Sci. Technol. 2002, 62, 1357-1372. [CrossRef]

266. Dwivedi, U.K.; Chand, N. Influence of MA-g-PP on abrasive wear behaviour of chopped sisal fibre reinforced polypropylene composites. J. Mater. Process. Technol. 2009, 209, 5371-5375. [CrossRef]

267. Zhang, M.; Rong, M.; Lu, X. Fully biodegradable natural fiber composites from renewable resources: All-plant fiber composites. Compos. Sci. Technol. 2005, 65, 2514-2525. [CrossRef] 
268. Athijayamani, A.; Thiruchitrambalam, M.; Natarajan, U.; Pazhanivel, B. Effect of moisture absorption on the mechanical properties of randomly oriented natural fibers/polyester hybrid composite. Mater. Sci. Eng. A 2009, 517, 344-353. [CrossRef]

269. Sangthong, S.; Pongprayoon, T.; Yanumet, N. Mechanical property improvement of unsaturated polyester composite reinforced with admicellar-treated sisal fibers. Compos. Part. A Appl. Sci. Manuf. 2009, 40, 687-694. [CrossRef]

270. Megiatto, J.D., Jr.; Silva, C.G.; Rosa, D.S.; Frollini, E. Sisal chemically modified with lignins: Correlation between fibers and phenolic composites properties. Polym. Degrad. Stab. 2008, 93, 1109-1121. [CrossRef]

271. Megiatto, J.D., Jr.; Ramires, E.C.; Frollini, E. Phenolic matrices and sisal fibers modified with hydroxy terminated polybutadiene rubber: Impact strength, water absorption, and morphological aspects of thermosets and composites. Ind. Crop. Prod. 2010, 31, 178-184. [CrossRef]

272. Ramires, E.C.; Megiatto, J.D., Jr.; Gardrat, C.; Castellan, A.; Frollini, E. Biobased composites from glyoxal-phenolic resins and sisal fibers. Bioresour. Technol. 2010, 101, 1998-2006. [CrossRef]

273. Athijayamani, A.; Thiruchitrambalam, M.; Natarajan, U.; Pazhanivel, B. Influence of alkali-treated fibers on the mechanical properties and machinability of roselle and sisal fiber hybrid polyester composite. Polym. Compos. 2010, 31, 723-731. [CrossRef]

274. Chand, N.; Jain, D. Effect of sisal fibre orientation on electrical properties of sisal fibre reinforced epoxy composites. Compos. Part. A Appl. Sci. Manuf. 2005, 36, 594-602. [CrossRef]

275. Meddahi, A.; Ait Tahar, K.; Bibi, M. Studies of sisal fiber-containing composites. J. Nat. Fibers 2008, 5, 36-46. [CrossRef]

276. de Andrade Silva, F.; Mobasher, B.; Toledo Filho, R.D. Cracking mechanisms in durable sisal fiber reinforced cement composites. Cem. Concr. Compos. 2009, 31, 721-730. [CrossRef]

277. Tonoli, G.H.D.; Santos, S.F.; Joaquim, A.P.; Savastano, H., Jr. Effect of accelerated carbonation on cementitious roofing tiles reinforced with lignocellulosic fibre. Constr. Build. Mater. 2010, 24, 193-201. [CrossRef]

278. Towo, A.N.; Ansell, M.P. Fatigue of sisal fibre reinforced composites: Constant-life diagrams and hysteresis loop capture. Compos. Sci. Technol. 2008, 68, 915-924. [CrossRef]

279. Wongsorat, W.; Suppakarn, N.; Jarukumjorn, K. Mechanical Properties, Morphological Properties, and Cure Characteristics of Sisal Fiber/Natural Rubber Composites: Effects of Fiber and Compatibilizer Content. Adv. Mater. Res. 2010, 123, 1171-1174.

280. de Paula, M.P.; Lacerda, T.M.; Frollini, E. Sisal cellulose acetates obtained from heterogeneous reactions. Express Polym. Lett 2008, 2, 423-428. [CrossRef]

281. Bakare, I.O.; Okieimen, F.E.; Pavithran, C.; Khalil, H.P.S.A.; Brahmakumar, M. Mechanical and thermal properties of sisal fiber-reinforced rubber seed oil-based polyurethane composites. Mater. Des. 2010, 31, 4274-4280. [CrossRef]

282. Favaro, S.L.; Ganzerli, T.A.; de Carvalho Neto, A.G.V.; da Silva, O.; Radovanovic, E. Chemical, morphological and mechanical analysis of sisal fiber-reinforced recycled high-density polyethylene composites. Express Polym. Lett. 2010, 4, 465-473. [CrossRef]

283. Diyana, Z.N.; Jumaidin, R.; Selamat, M.Z.; Ghazali, I.; Julmohammad, N.; Huda, N.; Ilyas, R.A. Physical Properties of Thermoplastic Starch Derived from Natural Resources and Its Blends: A Review. Polymers 2021, 13, 1396. [CrossRef]

284. Supian, A.B.M.; Sapuan, S.M.; Jawaid, M.; Zuhri, M.Y.M.; Ilyas, R.A.; Syamsir, A. Crashworthiness Response of Filament Wound Kenaf/Glass Fibre-reinforced Epoxy Composite Tubes with Influence of Stacking Sequence under Intermediate-velocity Impact Load. Fibers Polym. 2021, 1-12. [CrossRef]

285. Kandachar, P.; Brouwer, R. Applications of bio-composites in industrial products. MRS Online Proc. Libr. 2001, 702, 1-12. [CrossRef]

286. Eichhorn, S.J.; Baillie, C.A.; Zafeiropoulos, N.; Mwaikambo, L.Y.; Ansell, M.P.; Dufresne, A.; Entwistle, K.M.; Herrera-Franco, P.J.; Escamilla, G.C.; Groom, L. Current international research into cellulosic fibres and composites. J. Mater. Sci. 2001, 36, $2107-2131$. [CrossRef]

287. Jústiz-Smith, N.G.; Virgo, G.J.; Buchanan, V.E. Potential of Jamaican banana, coconut coir and bagasse fibres as composite materials. Mater. Charact. 2008, 59, 1273-1278. [CrossRef]

288. Van De Velde, K.; Kiekens, P. Thermal degradation of flax: The determination of kinetic parameters with thermogravimetric analysis. J. Appl. Polym. Sci. 2002, 83, 2634-2643. [CrossRef]

289. Srinivasan, V.; Rajendra Boopathy, S.; Sangeetha, D.; Vijaya Ramnath, B. Evaluation of mechanical and thermal properties of banana-flax based natural fibre composite. Mater. Des. 2014, 60, 620-627. [CrossRef]

290. Olusegun, D.S.; Stephen, A.; Adekanye, T.A. Assessing mechanical properties of natural fibre reinforced composites for engineering applications. J. Miner. Mater. Charact. Eng. 2012, 11, 780-784.

291. Yan, L.; Chouw, N.; Jayaraman, K. Flax fibre and its composites-A review. Compos. Part. B Eng. 2014, 56, 296-317. [CrossRef]

292. Ho, M.; Wang, H.; Lee, J.-H.; Ho, C.; Lau, K.; Leng, J.; Hui, D. Critical factors on manufacturing processes of natural fibre composites. Compos. Part. B Eng. 2012, 43, 3549-3562. [CrossRef]

293. Satyanarayana, K.G.; Sukumaran, K.; Mukherjee, P.S.; Pavithran, C.; Pillai, S.G.K. Natural fibre-polymer composites. Cem. Concr. Compos. 1990, 12, 117-136. [CrossRef]

294. Brischetto, S. A comparative study of composite structures reinforced with carbon, glass or natural fibers. Multidiscip. Model. Mater. Struct. 2017, 17, 165-187. [CrossRef]

295. Joseph, S.; Sreekala, M.S.; Oommen, Z.; Koshy, P.; Thomas, S. A comparison of the mechanical properties of phenol formaldehyde composites reinforced with banana fibres and glass fibres. Compos. Sci. Technol. 2002, 62, 1857-1868. [CrossRef]

296. Aziz, S.H.; Ansell, M.P. The effect of alkalization and fibre alignment on the mechanical and thermal properties of kenaf and hemp bast fibre composites: Part 1—Polyester resin matrix. Compos. Sci. Technol. 2004, 64, 1219-1230. [CrossRef] 
297. Alamri, H.; Low, I.M. Effect of water absorption on the mechanical properties of n-SiC filled recycled cellulose fibre reinforced epoxy eco-nanocomposites. Polym. Test. 2012, 31, 810-818. [CrossRef]

298. Alamri, H.; Low, I.M. Mechanical properties and water absorption behaviour of recycled cellulose fibre reinforced epoxy composites. Polym. Test. 2012, 31, 620-628. [CrossRef]

299. Dittenber, D.B.; Gangarao, H.V.S. Critical review of recent publications on use of natural composites in infrastructure. Compos. Part. A Appl. Sci. Manuf. 2012, 43, 1419-1429. [CrossRef]

300. Shibata, S.; Cao, Y.; Fukumoto, I. Press forming of short natural fiber-reinforced biodegradable resin: Effects of fiber volume and length on flexural properties. Polym. Test. 2005, 24, 1005-1011. [CrossRef]

301. Pothan, L.A.; Thomas, S.; Neelakantan, N.R. Short banana fiber reinforced polyester composites: Mechanical, failure and aging characteristics. J. Reinf. Plast. Compos. 1997, 16, 744-765. [CrossRef]

302. Ray, D.; Sarkar, B.K.; Bose, N.R. Impact fatigue behaviour of vinylester resin matrix composites reinforced with alkali treated jute fibres. Compos. Part. A Appl. Sci. Manuf. 2002, 33, 233-241. [CrossRef]

303. Sanjay, M.R.; Arpitha, G.R.; Laxmana Naik, L.; Gopalakrishna, K.; Yogesh, B. Studies on mechanical properties of banana/e-glass fabrics reinforced polyester hybrid composites. J. Mater. Environ. Sci. 2016, 7, 3179-3192.

304. Zampaloni, M.; Pourboghrat, F.; Yankovich, S.A.; Rodgers, B.N.; Moore, J.; Drzal, L.T.; Mohanty, A.K.; Misra, M. Kenaf natural fiber reinforced polypropylene composites: A discussion on manufacturing problems and solutions. Compos. Part. A Appl. Sci. Manuf. 2007, 38, 1569-1580. [CrossRef]

305. Magurno, A. Vegetable fibres in automotive interior components. Die Angew. Makromol. Chem. 1999, 272, 99-107. [CrossRef]

306. Schuh, T.G. Renewable Materials for Automotive Applications; Daimler-Chrysler, A., Ed.; CRC Press: Boca Raton, FL, USA, 1999.

307. Wahab, M.; Sapuan, S.M.; Harussani, M.M.; Zuhri, M.Y.M.; Saleh, A.A. Conceptual Design of Glass/Renewable Natural Fibre-Reinforced Polymer Hybrid Composite Motorcycle Side Cover. J. Renew. Mater. 2021, 9, 1973-1989. [CrossRef]

308. Prabhu, L.; Krishnaraj, V.; Sathish, S.; Gokulkumar, S.; Karthi, N.; Rajeshkumar, L.; Balaji, D.; Vigneshkumar, N.; Elango, K.S. A review on natural fiber reinforced hybrid composites: Chemical treatments, manufacturing methods and potential applications. Mater. Today Proc. 2021, 45, 8080-8085. [CrossRef]

309. Joshi, S.V.; Drzal, L.T.; Mohanty, A.K.; Arora, S. Are natural fiber composites environmentally superior to glass fiber reinforced composites? Compos. Part. A Appl. Sci. Manuf. 2004, 35, 371-376. [CrossRef]

310. Yu, H.N.; Kim, S.S.; Hwang, I.U. Application of natural fiber reinforced composites to trenchless rehabilitation of underground pipes. Compos. Struct. 2008, 86, 285-290. [CrossRef]

311. Moreau, R. Nautical Activities: What Impact on the Environment? A Life Cycle Approach for "Clear Blue" Boating-Commissioned by the European Confederation of Nautical Industries-ECNI. 2009. Available online: https:/ /www.europeanboatingindustry.eu/ images/Documents/For_publications/Nautical-activities_what-impact-on-the-environment.pdf (accessed on 8 October 2021). 